\title{
Сингулярность XXI века в контексте Большой истории: математический анализ ${ }^{1}$
}

\author{
А. В. Коротаев \\ Евроазиатский центр Большой истории и системного \\ прогнозирования Института востоковедения РАН, \\ Национальный исследовательский университет «Высшая школа экономики», \\ Факультет глобальных МГУ им. М. В. Ломоносова
}

Correspondence |A. B. Коротаев, akorotayev@gmail.com

Citation | Коротаев, А. В. (2018) Сингулярность XXI века в контексте Большой истории: математический анализ . Journal of Big History, II(3); 17 - 71.

DOI | http://dx.doi.org/10.22339/jbh.v2i3.2310

\section{Аннотация.}

Представление о том, что в ближайшее время нас ждет некая «Сингулярность», стало в последнее время достаточно популярным, прежде всего благодаря деятельности технического директора Google в области технического обучения Рэймонда Курцвейла и его книге The Singularity Is Near (2005). Показано, что математический анализ приводимого им ряда событий, начинающегося с возникновения нашей Галактики и заканчивающегося расшифровкой кода ДНК, действительно практически идеально описывается (неизвестной самому Курцвейлу) крайне простой математической функцией с сингулярностью в районе 2029 г. Показано также, что составленный в начале 2000-х (совершенно независимо от Курцвейла) российким физиком А. Д. Пановым аналогичный временной ряд (начинающийся с возникновения жизни на Земле и заканчивающийся информационной революцией) также практически идеально описывается (не использованной А. Д. Пановом) математической функцией (крайне сходной с вышеупомянутой) с сингулярностью в районе 2027 г. Показано, что эта функция также чрезвычайно сходна с уравнением, открытым в 1960 г. Х. фон Ферстером, показавшим в своей знаменитой статье в журнале Science, что она практически идеально описывает динамику численности населения и характеризуется математической сингулярностью в районе 2027 г. Все это говорит о наличии достаточно строгих глобальных макроэволюционных закономерностей, которые могут удивительно точно описываться крайне простыми математическими функциями. Вместе с тем продемонстрировано, что в районе точки сингулярности нет основания вслед за Курцвейлом ожидать невиданного (на много порядков) ускорения темпов технологического развития; имеются бо́льшие основания интерпретировать эту точку как индикатор зоны перегиба, после прохождения которой темпы глобальной эволюции будут систематически в долгосрочной перспективе замедляться.

\section{Введение}

Вопрос о «сингулярности» глобальной (или даже Большой) истории обсуждается в последнее время очень активно (см., например: Назаретян 2013, 2014, 2015a, 20156; Eden et al. 2012; Shanahan 2015; Callaghan 2017; Nazaretyan 2015, 2016, 2017, 2018).

1. Исследование выполнено при поддержке Российского фонда фундаментальных исследований (проект № 17-06-
Этот вопрос был сделан особенно популярным благодаря усилиям Р. Курцвейла, технического директора в области машинного обучения и обработки естественного языка компании Google, и в особенности благодаря его книге The Singularity Is Near (2005), но также и через

00464) 
создание им Университета Сингулярности (2009), активную PR-кампанию и т.п. В сфере Большой истории ${ }^{2}$ внимание к проблеме Сингулярности было привлечено благодаря деятельности таких специалистов в этой области, как А. П. Назаретян (2005, 2009, 2013, 2014, 2015a, 2015б; Балашова и др. 2017; Nazaretyan 2005, 2015, 2016, 2017, 2018), А.Д.Панов (2004,2005,2006,2008; Panov2005,2011, 2017) и Г. Д. Снукс (Snooks 2005). В перспективе Большой истории «гипотеза Сингулярности» может представлять определенный интерес, так как она вроде предлагает «научно обоснованную» датировку «Девятой пороговой вехи Большой истории» (Big History Threshold 9). ${ }^{3}$ Однако попробуем прежде всего разобраться, могут ли математические расчеты даты Сингулярности нам действительно помочь выявить дату наступления очередной пороговой вехи Большой истории.

\section{Временной ряда Курцвейла - Модиса и математическая сингулярность}

Р. Курцвейл одним из первых расположил главные макроэволюционные сдвиги значительной части Большой истории вдоль гиперболической кривой, которая может быть описана уравнением c математической сингулярностью. ${ }^{4}$ Например,

2 Напомним, что по определению Международной ассоциации Большой истории, суть Большой истории заключается в «стремлении понять интегрированную историю Космоса, Земли, Жизни и Человечества с использованием надежных эмпирических данных и научных методов» (Big History seeks to understand the integrated history of the Cosmos, Earth, Life, and Humanity, using the best available empirical evidence and scholarly methods - https://bighistory.org/).

3 О понятии «пороговых вех Большой истории» (Big History Thresholds) см.: Christian 2008. Стоит, видимо, пояснить, что в качестве 5-й пороговой вехи Большой истории Д. Кристиан рассматривает возникновение жизни, 6-й - антропогенез и возникновение «коллективного обучения» (collective learning), 7-й - неолитическую революцию, а 8-й - глобальную модернизацию последних веков, особенно активно протеквшую в XIX-XX вв. (Modern Revolution).

4 Причины того, почему мы называем этот временной ряд «рядом Курцвейла - Модиса» станут понятны несколько ниже. на с. 18 своего бестселлера The Singularity is Near (Kurzweil 2005) он приводит следующую диаграмму (см. Рис. 1) $)^{5}$.

Однако, как это ни удивительно, Курцвейл, повидимому, не заметил, что кривая, представленная на этом рисунке, является гиперболической, и что она описывается уравнением, имеющим самую настоящую математическую сингулярность (более того значение этой сингулярности, 2029 год, не так далеко от того, что предсказывается самим Курцвейлом). Это объясняется, прежде всего, некоторыми математическими неточностями, характерными для технического директора Google (достаточно упомянуть, что он упорно называет глобальный паттерн ускорения эволюции «экспоненциальным», не обращая внимания на то, что экспоненциальная функция не имеет какойлибо сингулярности).

В свете этого не может не вызвать некоторого удивления то обстоятельство, что сам Курцвейл знает о понятии математической сингулярности и более или менее точно описывает его. Действительно, на страницах 22-23 своего бестселлера он дает довольно точное описание понятия «математическая сингулярность»:

“ Singularity - это английское слово,
означающее уникальное в своем
роде событие с крайне особенными
последствиями. Это слово используется
математиками для обозначения
значения, которое превосходит любое
конечное ограничение, такое как
взрывообразныйрост величины, который
возникает при делении константы на
переменную, значение которой все
больше приближается к нулю. Такая

5 Собственно говоря, прототип этого графика (но в двойной логарифмической шкале) можно найти на с. 5 в опубликованном Р. Курцвейлом в 2001 году эссе “Закон возрастающей отдачи» (Kurzweil 2001: 5). 


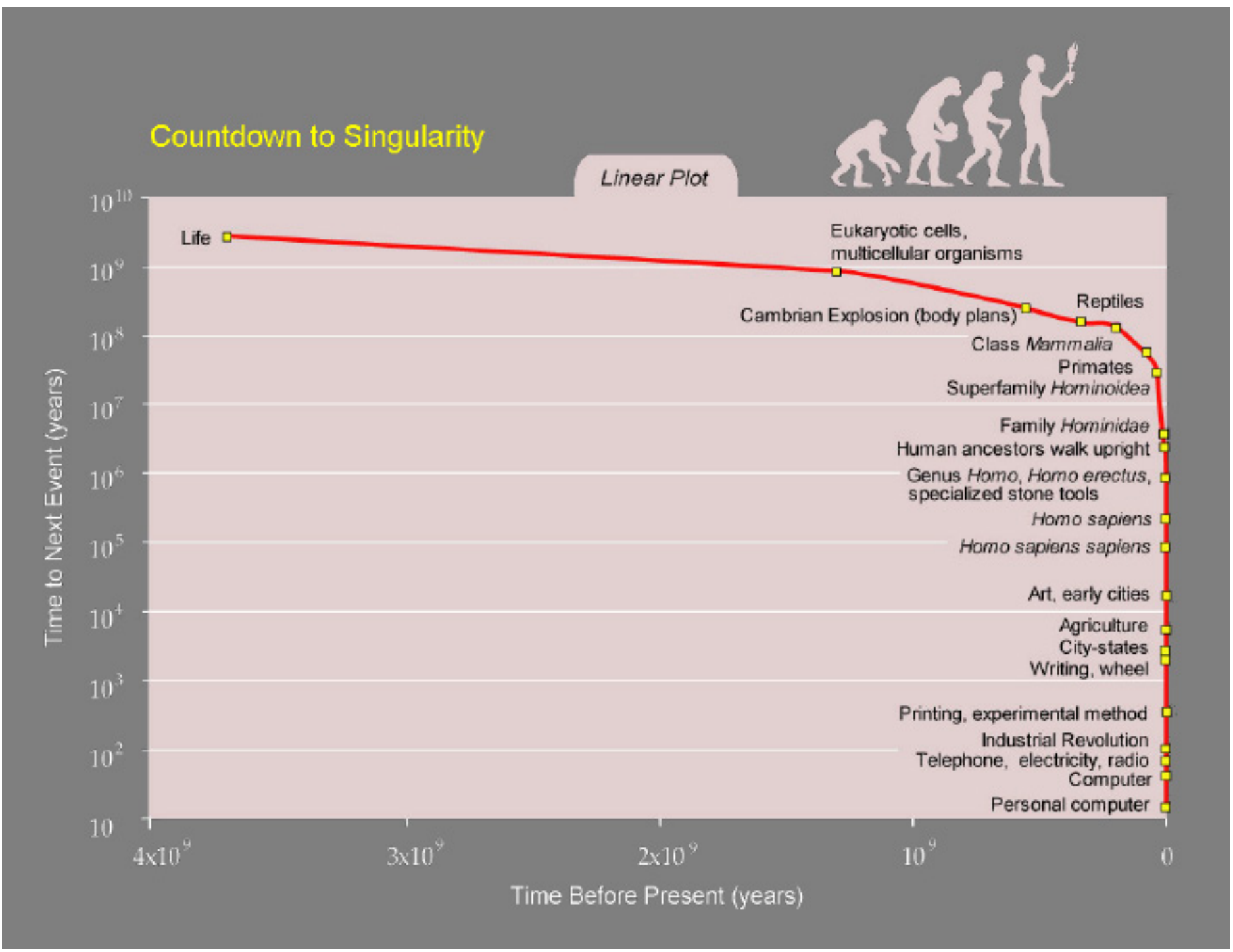

Рис 1. “Обратный отсчет времени до Сингулярности” согласно Р. Курцвейлу

Источник: Kurzweil 2005: 18.

математическая функция никогда не достигает бесконечного значения, так как деление на ноль математически «неопределено» (это невозможно вычислить). Но значение $y$ превосходит любой возможный конечный предел (приближается к бесконечности), когда знаменатель $x$ стремится к нулю” (р. 2223).
Более того, на с. 23 он сопровождает свое описание понятия «математическая сингулярность» вполне адекватным иллюстрирующим графиком (см. Рис. 2).

Однако, представив достаточно адекватное описание понятия «математическая сингулярность», Курцвейл, похоже, теряет интерес к этому понятию - внезапно переключаясь на использование термина «сингулярность» 


\section{A Mathematical Singularity Linear Plot}

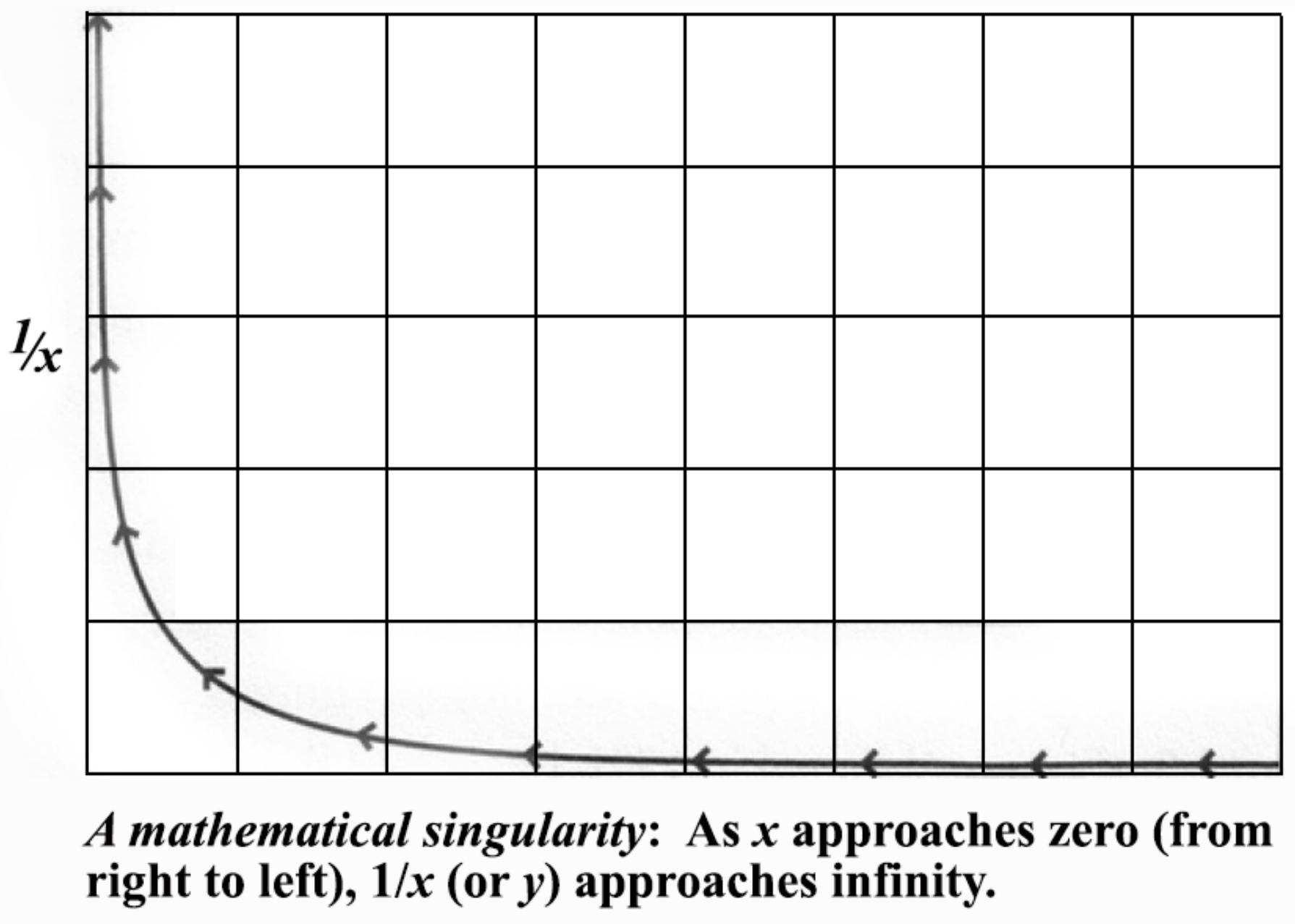

Рис. 2. Пример математической сингулярности (в натуральном масштабе)

Источник: Kurzweil 2005: 23.

астрофизиками (р. 23).

Одна из загадочных вещей в книге Курцвейла заключается в том, что он, похоже, не заметил, что форма гиперболической кривой на его графике «Математическая сингулярность» (стр. 23 книги Курцвейла, см. Рис. 2 выше) принципиально идентична (хотя, конечно, повернута на 180 градусов) с формой кривой на его графике «Обратный отсчет времени до Сингулярности» (стр. 18 той же книги, см. выше Рис. 1). Более того, как мы увидим ниже, математическая модель, обеспечивающая наилучшую аппроксимацию кривой типа той, что изображена на Рис. 1, в основном идентична гиперболической функции, показанной на Рис 2 , т.е. $y=k / x$. Таким образом, если бы Курцвейл сделал простой математический анализ временного ряда на своем Рис. 1, он бы нашел, что его лучше всего описывает математическое уравнение того самого типа, что он изображает на своем Рис. 2 (с той очень небольшой разницей что у нас в числителе уравнения оказалось бы «2», а не 
«1»). ${ }^{6}$ Более того, он обнаружил бы, что значение математической сингулярности уравнения, лучше всего описывающего кривую на графике «Обратный отсчет времени до Сингулярности» Курцвейла (см. выше Рис. 1), соответствует 2029 году, что не так сильно отличается от 2045 года, предложенного им в его книге, и что просто идентично с датой, предложенной Курцвейлом совсем недавно (см. Ranj 2016) ${ }^{7}$.

\section{Преобразование Панова}

Между тем, то, что не было сделано Р. Курцвейлом в 2005 году, было сделано в 2003 году А. Д. Пановым ${ }^{8}$. Панов проанализировал достаточно похожий временной ряд (построенный, впрочем, на совершенно других источниках) и пришел к очень похожим выводам, но в гораздо более продвинутой форме. Очень важно, что он совершил шаг (к которому Курцвейл был очень близок, но который он фактически не сделал), который позволил Панову сделать анализ рассматриваемого временного ряда гораздо более прозрачным, благодаря чему он смог точно

6 А при несколько ином расчете, чем тот что мы применим ниже, в знаменателе этого уравнения окажется число, слабо отличимое от «1» или даже просто равное «1» (см. Приложение 2).

7 Точнее, это дата, когда, согласно последнему прогнозу Курцвейла, люди станут бессмертными, что вполне можно рассматриваться как своего рода сингулярность (а также в качестве довольно вероятного кандидата на Девятую пороговую веху Большой истории) - даже если мы действительно имеем дело с радикальным увеличением ожидаемой продолжительности жизни человека (или постчеловека?), а не с бессмертием как таковым, поскольку это все равно будет означать изменение биологической природы людей, что не может не повлиять на ход человеческой истории самым драматичным образом.

8 Его описанные ниже расчеты были впервые представлены в ноябре 2003 года на Академическом семинаре Государственного астрономического института в Москве (Nazaretyan 2005: 69) и впоследствии опубликованы в его статьях (Панов 2004, 2005, 2006; Panov 2005, 2011, 2017) и монографии (Панов 2008: 19-40). рассчитать дату сингулярности.

В своей книге 2005 года Курцвейл отложил по оси ординат своих диаграмм «время для следующего события», что, на мой взгляд, существенно затруднило их интерпретацию. С другой стороны, в своем эссе 2001 года на стр. 5 при анализе диаграммы с аналогичным временным рядом (источник которого, кстати, не был указан) Курцвейл начал говорить об ускорении «скорости сдвига парадигм» (paradigm shift rate) (Kurzweil 2001: 5), но (что довольно типично для Главного инженера Google) почти сразу же переключился на другую тему. Вместе с тем то, что было необходимо для того, чтобы сделать его диаграммы гораздо более понятными, заключалось в том, чтобы отложить по оси ординат не «время до следующего события», а именно «скорость сдвига парадигм», как это сделал Панов. Действительно, чтобы преобразовать время до следующего «парадигмального сдвига» в скорость сдвига парадигм, нужно было сделать довольно простую вещь: взять один год и разделить его на время до следующего сдвига парадигм; в результате, мы получим число парадигмальных сдвигов в год, то есть именно «скорость сдвига парадигм». Как мы уже говорили, это не было сделано Курцвейлом, но было сделано Пановым, получившим в результате следующие графики (см. Рис.3).

График $3 \mathrm{a}$ рисунка 3 описывает ускорение глобальной скорости макроэволюции начиная с 4 миллиардов лет до настоящего времени, тогда как левый график (3b) описывает это для человеческой части Большой Истории. Заметим сразу, что кривая 3а Панова является зеркальным отображением графика «Обратный отсчет времени до сингулярности» Курцвейла (см. Рис. 4).

Однако математическая интерпретация графика Панова намного проще и нагляднее. Заметим, что сам Панов обозначал переменную, нанесенную по оси ординат его графиков как «Частоту 


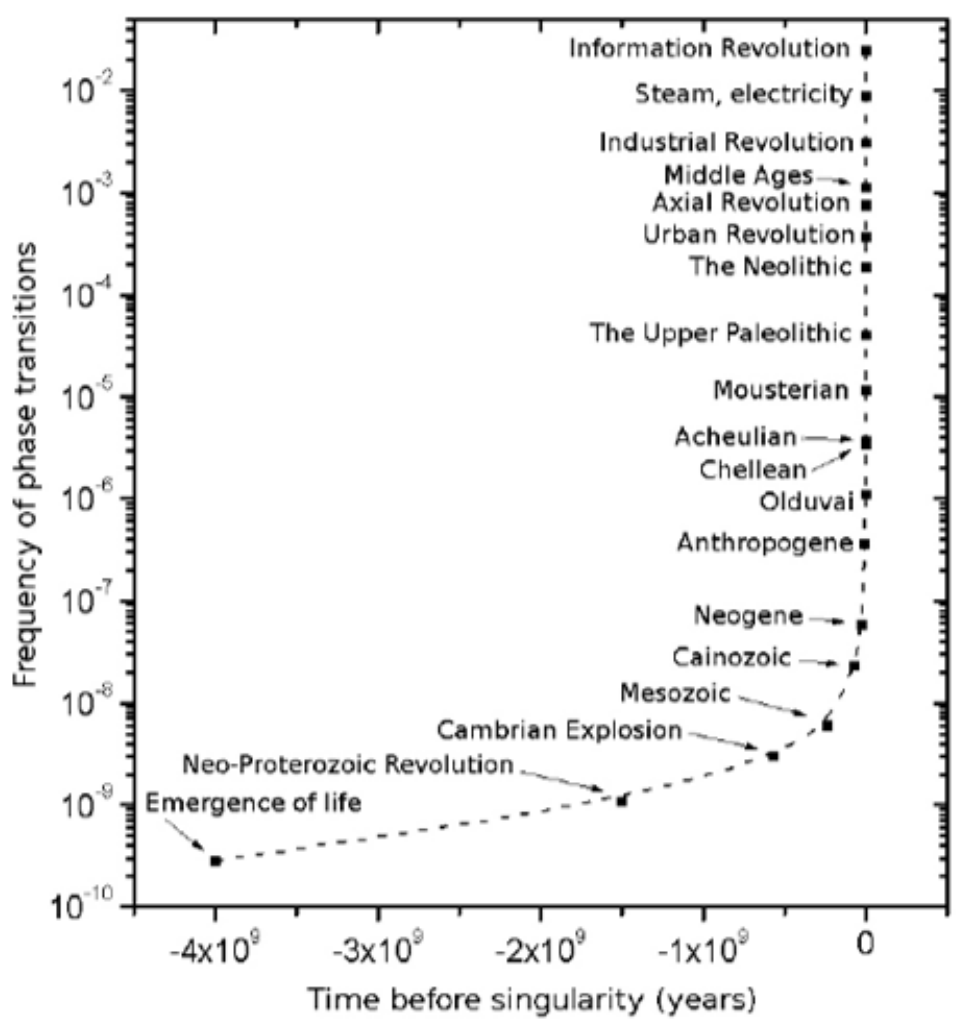

a)

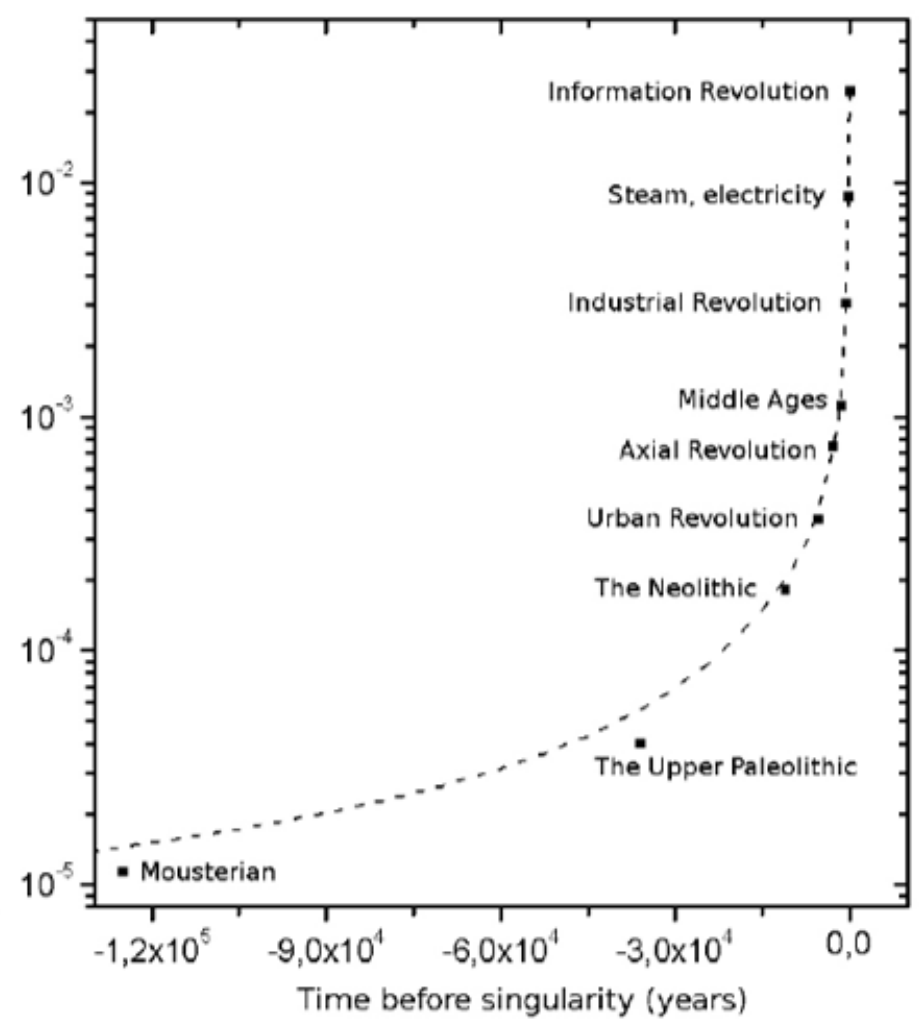

b)

Рис. 3. Динамика скорости глобального макроэволюционного развития согласно Панову (источник: Назаретян 2015: 760, Рис. 3).
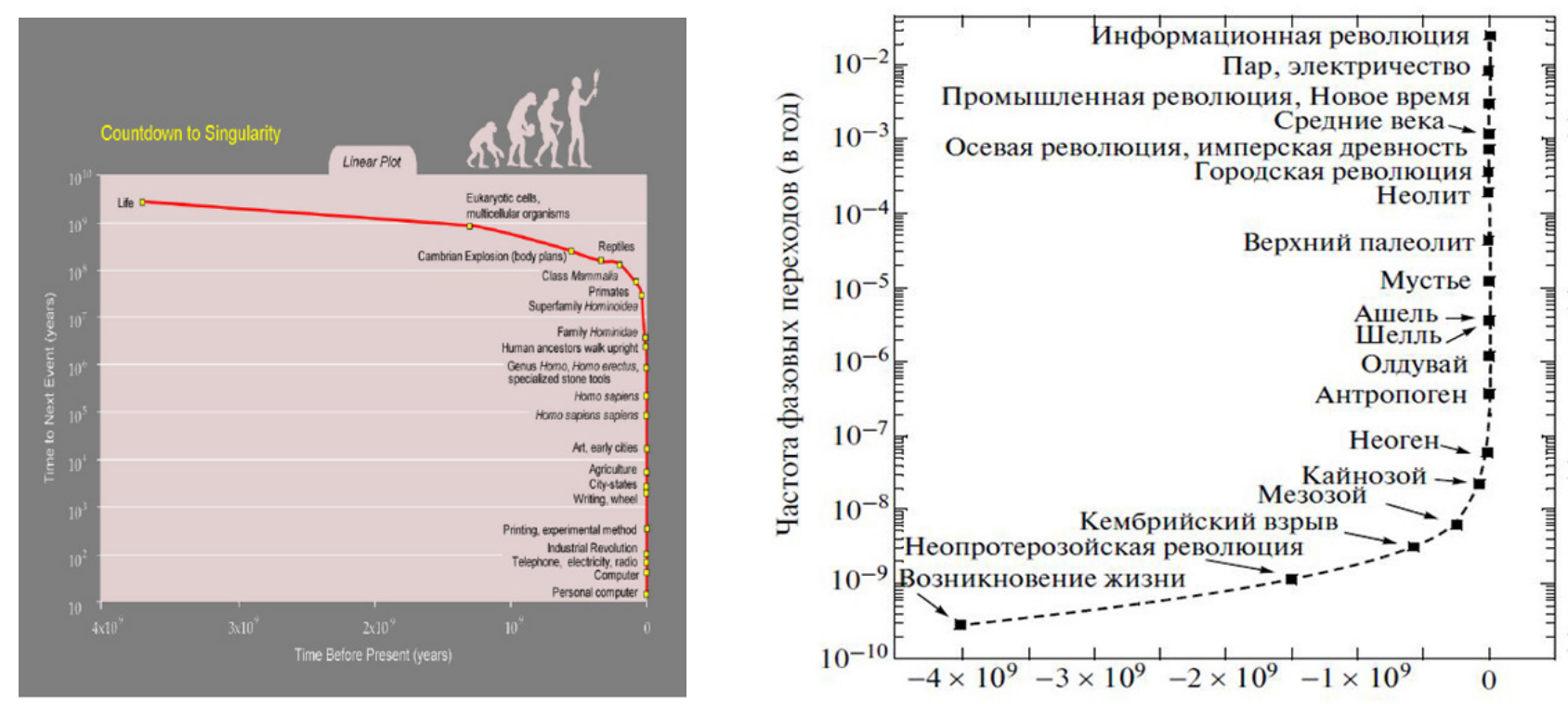

Рис. 4. Сравнение между «Счетом времени до сингулярности» Р. Курцвейла и графическим изображением А. Д. Пановым динамики «частоты глобальных фазовых переходов» (= глобальной скорости макроэволюционного развития) 


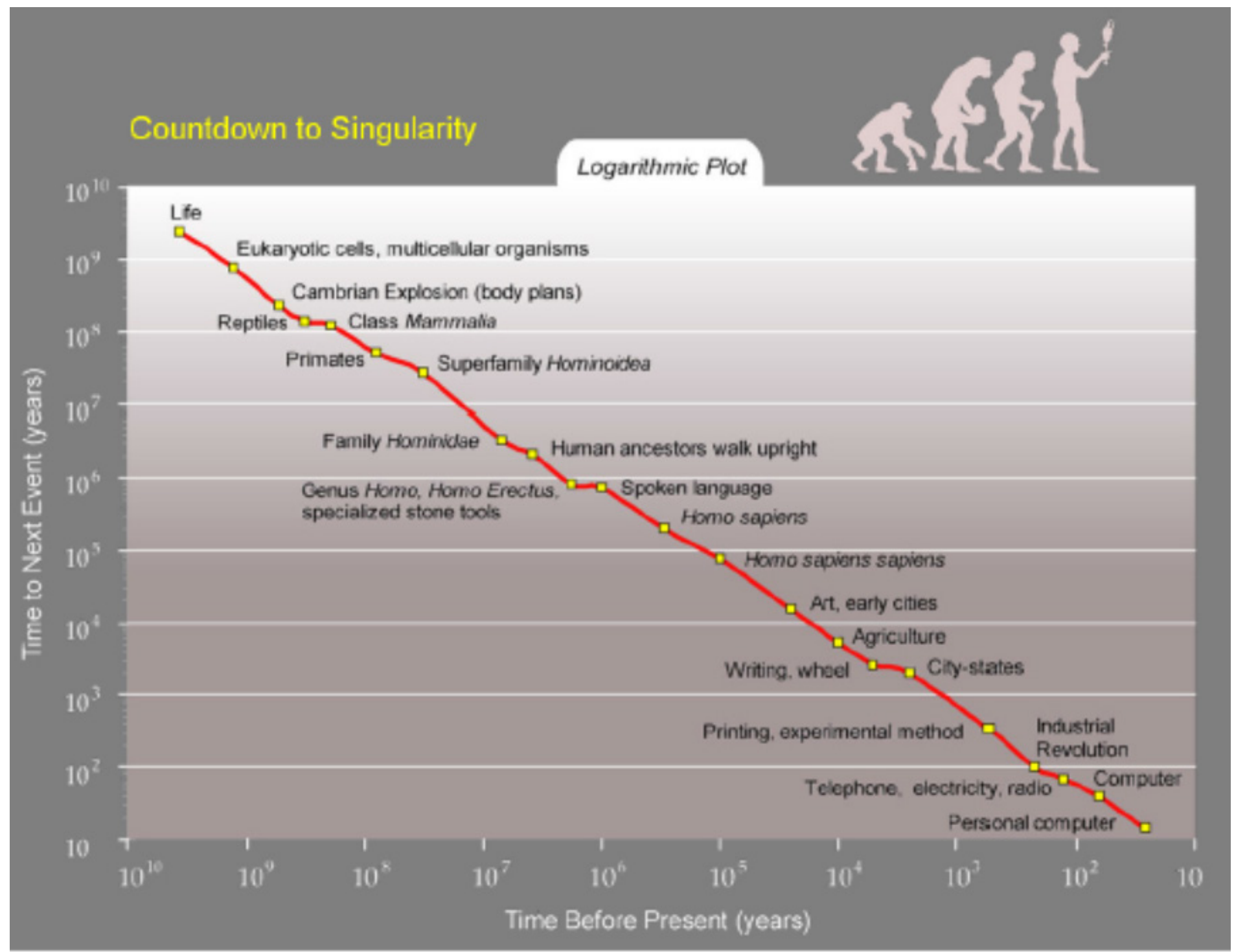

Рис. 5. Первая версия курцвейлского графика «Обратный отсчет времени до Сингулярности» в двойной логарифмической шкале Источник: Kurzweil 2005: 17.

фазовых переходов в год». Однако совершенно очевидно, что «фазовый переход» Панова является синонимом «сдвига парадигм» Курцвейла, тогда как «частота фазовых переходов в год» описывает именно «скорость парадигмальных сдвигов» или темпы глобального макроэволюционного развития/темпы роста глобальной сложности. Это преобразование значительно упрощает точное определение картины ускорения темпов глобального макроэволюционного развития.

\section{Временной ряд Курцвейла - Модиса: формальный анализ}

Ниже мы проведем математический анализ временного ряда Курцвейла - Модиса по линии, предложенной Пановым (хотя и с некоторыми нашими модификациями).

В дополнение к курцвейловскому графику «Обратный отсчет времени до Сингулярности» в одинарной логарифмической шкале представленной выше на Рис. 1, Курцвейл 
публикует две другие версии этого графика в двойной логарифмической шкале (см. Рис. 5 и 6).

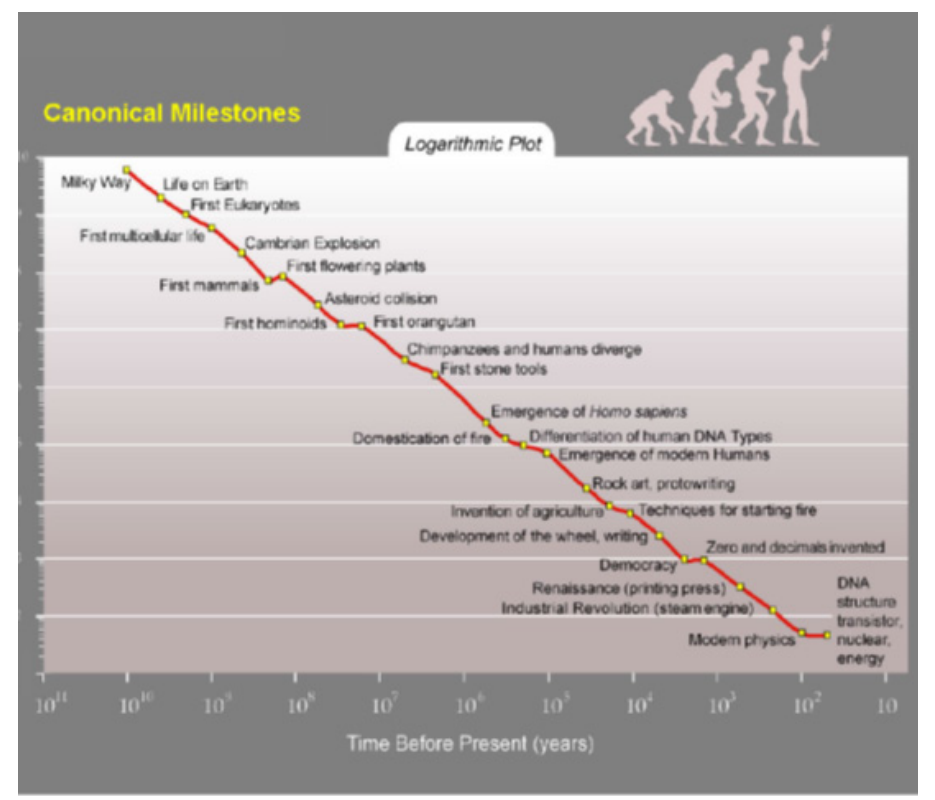

Рис. 6. Вторая версия курцвейлского графика «Обратный отсчет времени до Сингулярности» («Канонические вехи», Canonical Milestones) в двойной логарифмической шкале

Источник: Kurzweil 2005: 20.

Хотя временной ряд, представленный на рисунке 5, представляется мне несколько более обоснованным, чем тот, который представлен на рисунке 6 , я решил проанализировать временной ряд на рисунке 6 по следующей причине. Дело в том, что источник данных для рис. 5 остается мне совершенно неясным; следовательно, я не вижу способа восстановить соответствующий временной ряддо тех деталей, которыенеобходимы для его формального математического анализа. Но таких проблем нет с источником данных для Рис. 6, поскольку Курцвейл указывает его совершенно четко. Это статья Теодора Модиса «Пределы сложности и изменения» (Modis 2003), подготовленная в свою очередь на основе его предыдущей статьи, опубликованной в известном научном журнале Technological Forecasting and Social Change (Modis 2002). К счастью, Модис публикует все необходимые данные в своих статьях по своему временному ряду, что дает возможность его математически анализировать.

Мы начнем наш анализ с вышеупомянутого преобразования, т.е. заменим «время до следующего события» на «интенсивность парадигмальных сдвигов» «частоту фазовых переходов» «скорость глобального макроэволюционного развития» «скорость роста глобальной сложности». Результат выглядит следующим образом (см. Рис. $7^{9}$ ).

C использованием же той техники, которая была применена Р. Курцвейлом при построении своего графика «Обратный отсчет времени до Сингулярности» (см. выше Рис. 1), мы получим для анализируемого нами временного ряда следующий график (см. Рис. $8^{10}$ ).

На Рис. 9 легко увидеть, что один график является зеркальным отражением другого (см. Рис. 9).

Хорошо видно, что кривая на рис.7 (= рис. 9а) практически идентична с гиперболической кривой на рис. 2, иллюстрирующей математическую функцию с сингулярностью.

На следующем шаге отложим по оси абсцисс время до Сингулярности, а по оси ординат скорость глобальной макроэволюции (число фазовых переходов в единицу времени) и вычислим дату сингулярности, получив (методом наименьших квадратов) такую гиперболическую кривую, которая наиболее точно описывает анализируемый нами временной ряд. Результаты этого анализа представлены на Рис. 10 (как уже упоминалось выше, наш математический анализ определил дату сингулярности для этого временного ряда как 2029 г. н. э.). Ниже тот же самый график представлен в двойной логарифмической шкале (см. Рис. 11).

9 См. выше Рис. 6.

10 См. выше Рис. 6. 


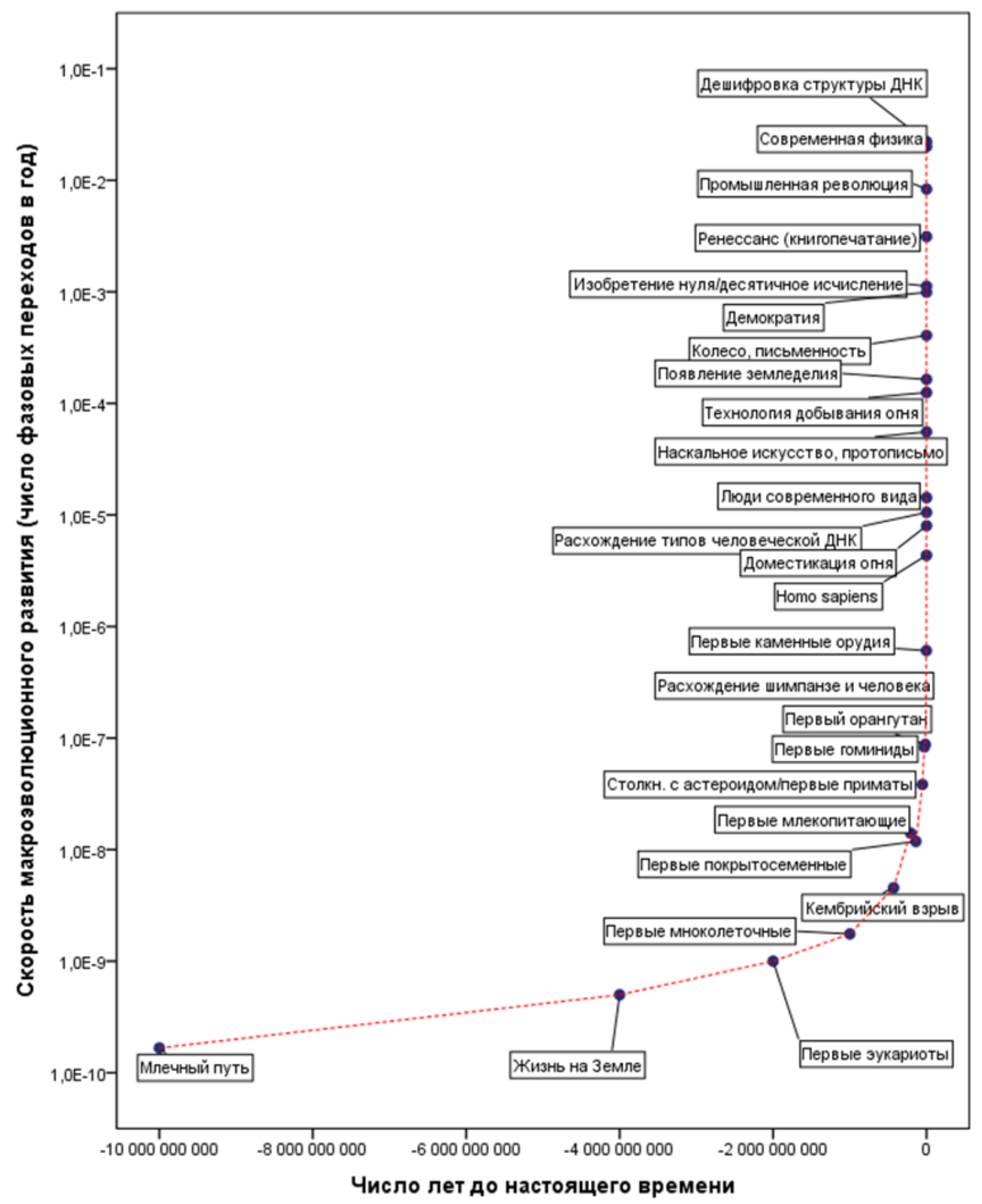

Рис. 7. График Курцвейла «Каноноческие вехи», трансформированный с использованием преобразования Панова (с логарифмической шкалой по оси ординат) 


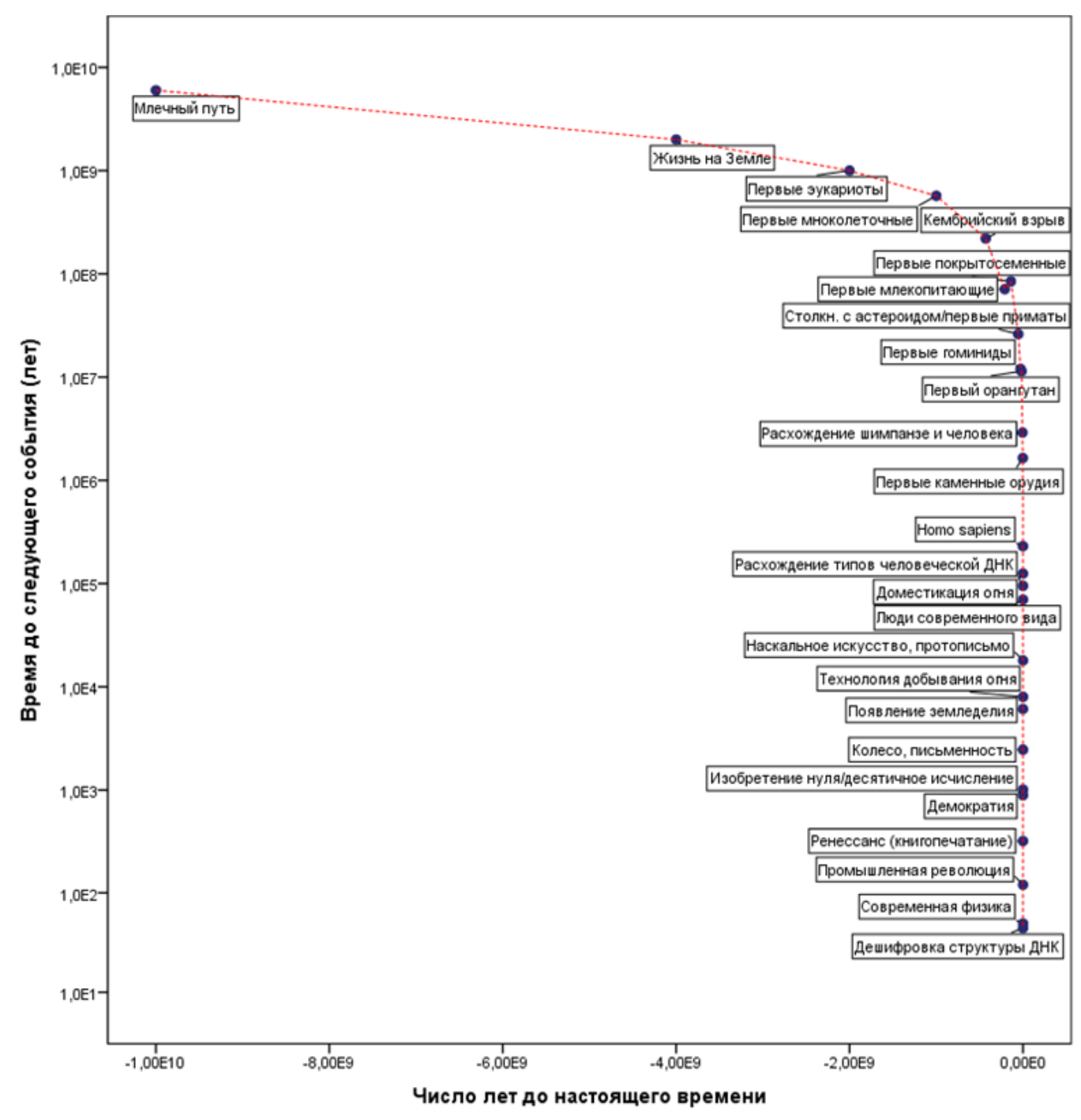

Рис. 8. Курцвейловский график «Канонические вехи» с логарифмической шкалой по оси ординат 

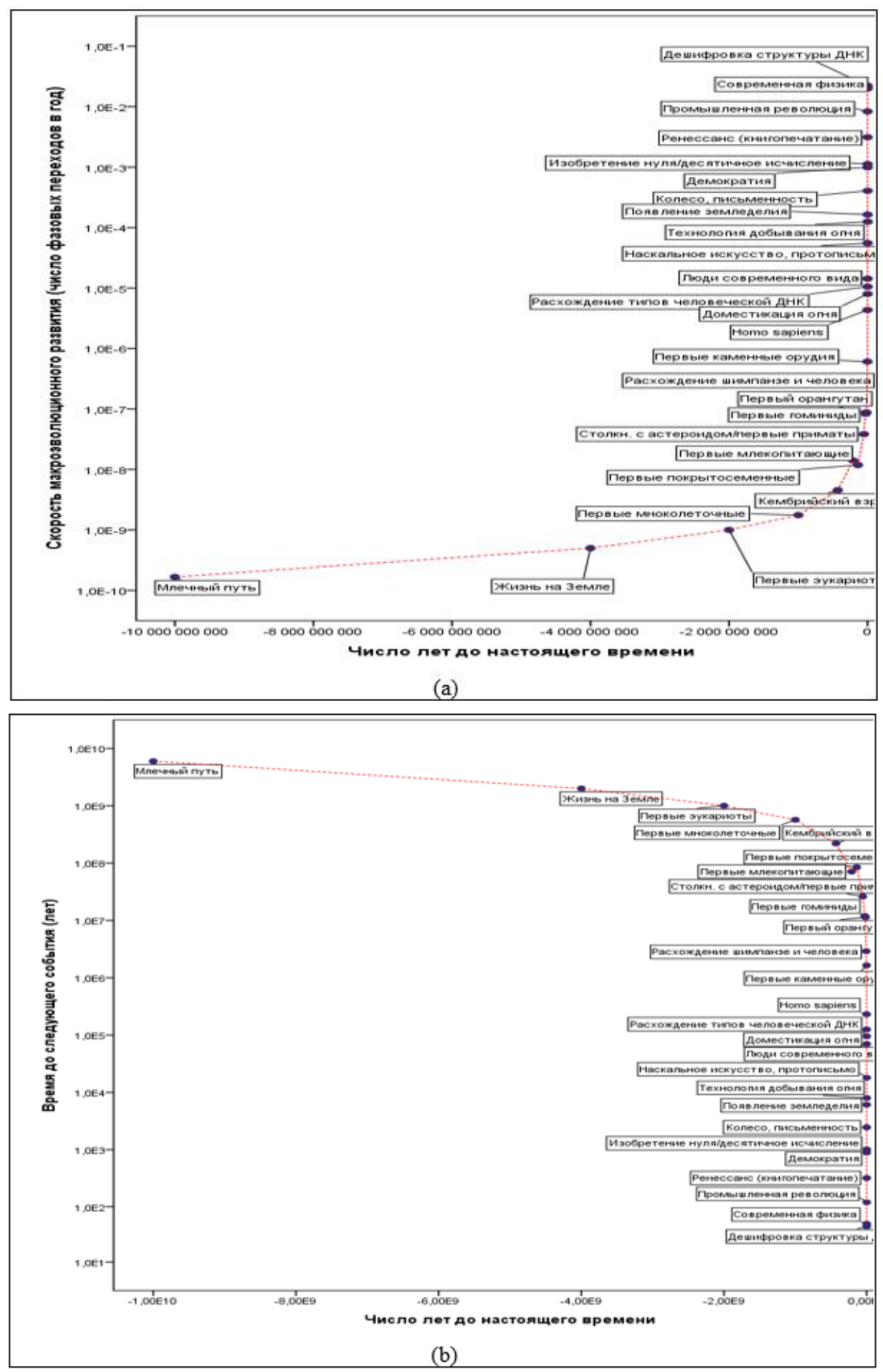

Рис. 9. График «по Панову» (а) является зеркальным отражением «курцвейловского» (b).
Теперь проанализируем полученные нами результаты. Как мы видим, временной ряд Модиса - Курцвейла c чрезвычайно высокой точностью описывается с помощью математической функции типа $\mathrm{y}=\mathrm{k} / \mathrm{x}$, имеющей откровенно выраженную математическую сингулярность, которую Курцвейл вполне точно охарактеризовал на страницах 22-23 его книги - к удивлению, не обратив внимание на ее релевантность для математического описания временного ряда «Обратный отсчет времени до сингулярности», представленного им всего за несколько страниц до этого (стр. 17-20). Действительно, наша степенная регрессия для рассматриваемого нами курцвейловского временного ряда «Обратный отсчет времени до сингулярности» определила следующее наилучше подходящее уравнение, описывающее этот временной ряд с почти идеальной точностью $\left(\mathrm{R}^{2}=\right.$ 0.999(!)).

$$
y=\frac{2,054}{x}
$$

где у - это скорость роста глобальной сложности (число фазовых переходов за единицу времени), х - время до Сингулярности, а 2,054 и 1,003 - константы. 


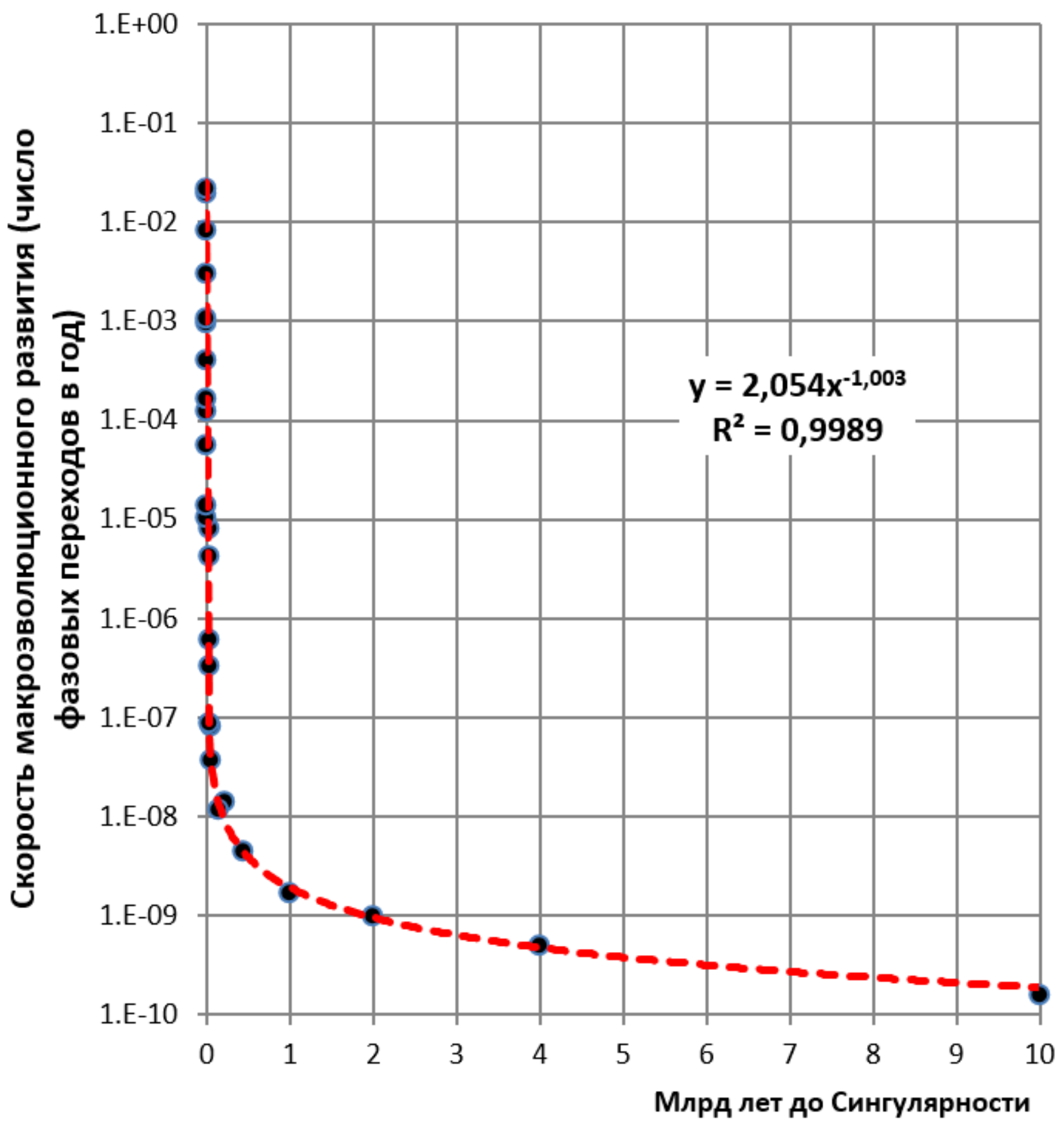

Рис. 10. Диаграмма рассеивания (с логарифмической шкалой по оси ординат) для точек фазовых переходов из списка Модиса - Курцвейла с добавленной линией степенной регрессии с датой Сингулярности, идентифицированной методом наименьших квадратов в районе 2029 г. н.э. 


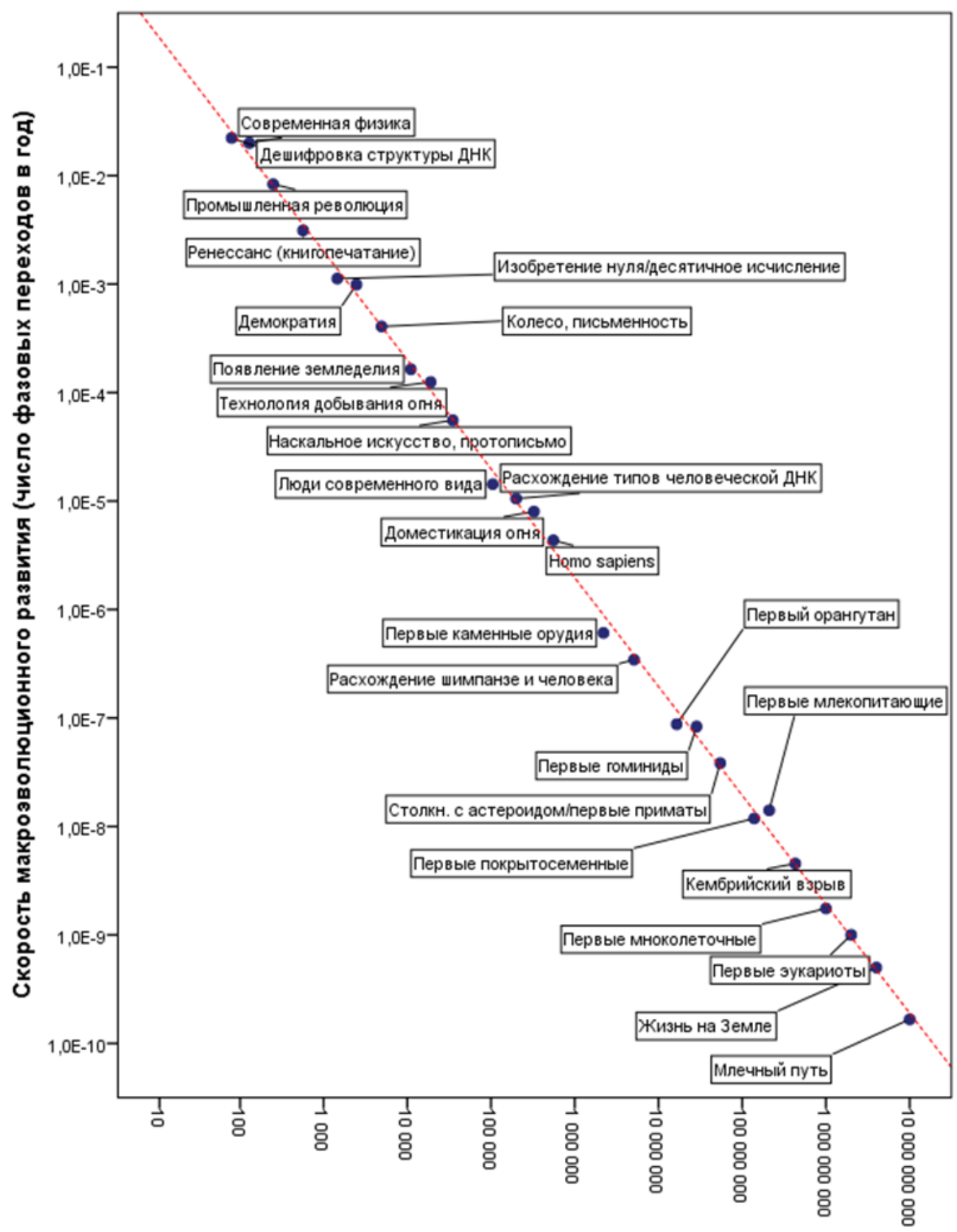

Время до Сингулярности (лет)

Рис. 11. Диаграмма рассеивания (в ДВОЙНОЙ логарифмической шкале) для точек фазовых переходов из списка Модиса - Курцвейла с наложенной линией степенной регрессии с датой Сингулярности, идентифицированной методом наименьших квадратов в районе 2029 г. н.э. 
Отметим, что показатель степень знаменателя (1,003) лишь в пренебрежимо малой степени отличается от «1» (полностью в пределах погрешности); таким образом, имеются все основания использовать это уравнение в следующей упрощенной форме:

$$
y=\frac{2,054}{x}
$$

где $y$ - это скорость роста глобальной сложности (число фазовых переходов за единицу времени), $x$ - время до Сингулярности, а 2,054 - константа.

Таким образом, оказывается, что временной ряд Модиса - Курцвейла может с удивительно высокой точностью математически описан при помощи той самой простой гиперболической функции, которую Курцвейл представляет на страницах 22-23 своей книги - с той лишь разницей, что в знаменателе правой части этого уравнения находится 2 (а не 1$)^{11}$.

\section{Экспоненциальная и гиперболическая формулы глобального ускорения}

Особо стоит подчеркнуть, что проведенный нами анализ достаточно строго демонстрирует, что паттерн ускорения роста глобальной сложности, прослеживаемый во временном ряде Модиса Курцвейла, являетсяНЕэкспоненциальным (какэто

11 Или, точнее, 2,054. Вместе с тем отметим, что подсчеты А. А. Фомина (2018) показывают, что если при расчете при помощи данной модели в качестве $t$ брать не момент . начала периода по которому вычисляется производная, а его середину, то значение параметра в знаменателе оказывается ближе скорее к 1 , чем к 2 .

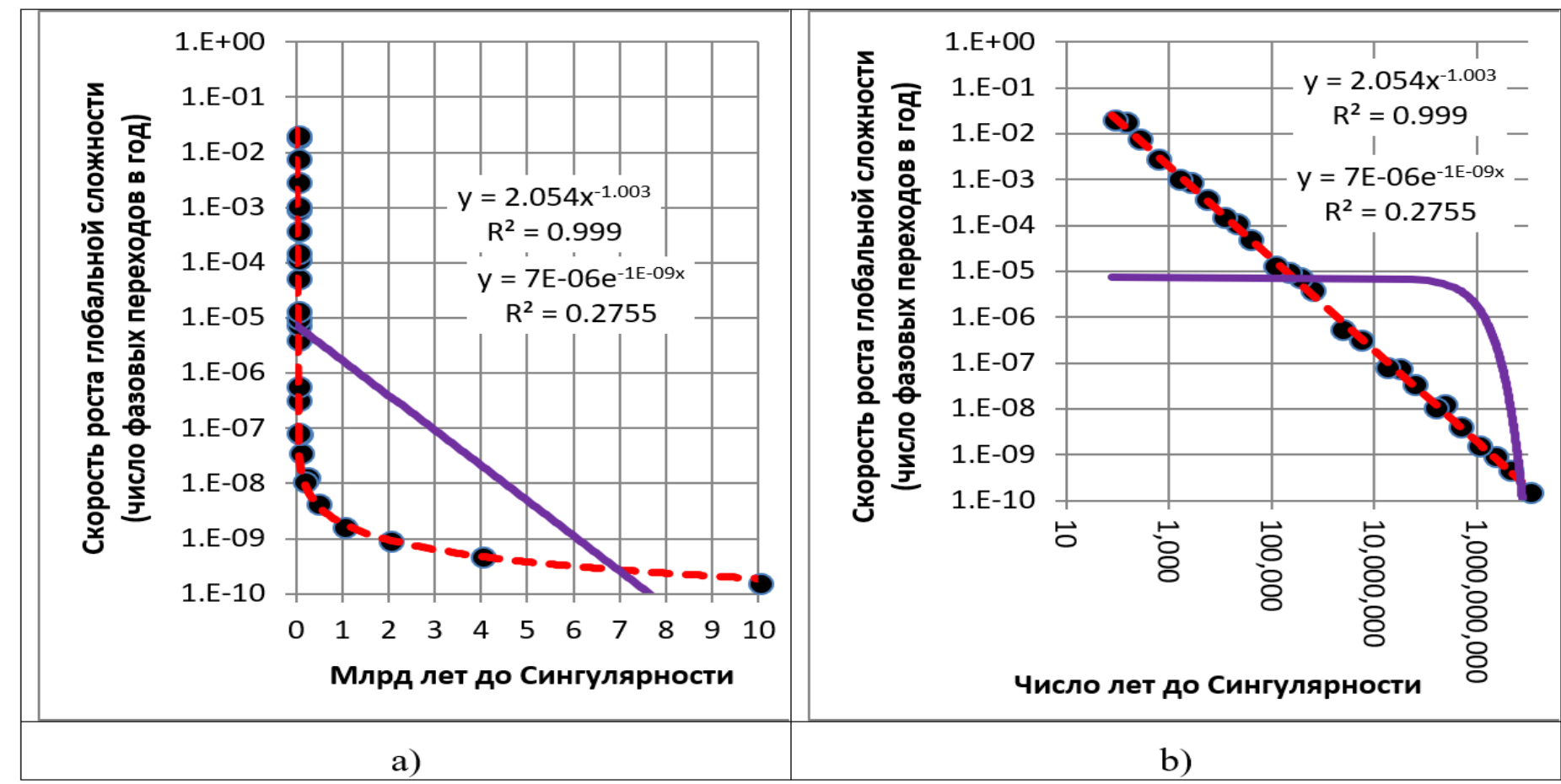

Рис. 12. Диаграмма рассеивания для точек фазовых переходов из списка Модиса - Курцвейла с наложенными линиями степенной/гиперболической и экспоненциальной регрессии: а) с логарифмической шкалой по оси ординат; b) в двойной логарифмической шкале. Сплошные регрессионные линии были сгенерированы экспоненциальной моделью, продемонстрировавшей (методом наименьших квадратов) наилучшее соответствие эмпирическим оценкам, пунктирные линии - гиперболическим уравнением. 
утверждает Курцвейл), а гиперэкспоненциальным, или, если быть более точными, гиперболическим (см. Рис. 12).

Стоит вспомнить, что при использовании логарифмической шкалы по оси ординат экспоненциальная кривая выглядит как прямая линия (в то время как гиперболическая линия выглядит похожей на экспоенциальную кривую). С другой стороны, в двойной логарифмической шкале гиперболическая кривая выглядит как

прямая линия, в то время как экспоненциальная кривая оказывается похожей на перевернутую экспоненциальную линию. Таким образом, Рис. 12 показывает, что Р. Курцвейл не вполне прав, когда утверждает, что глобальное макроэволюционное развитие ускорялось экспоненциально, демонстрируя, что это ускорение было отнюдь не экспоненциальным, а гиперболическим.

\section{Формула ускорения макроэволюционного по временному ряду Модиса - Курцвейла}

Чтобы сделать рассматриваемую нами модель ускорения более понятной, имеет смысл произвести небольшое преобразование уравнения (2). Напомним, что это уравнение представляет собой немного упрощенную версию уравнения (1), использованного для генерирования гиперболических кривых на Рис. 12; и выглядит оно следующим образом:

$$
y=\frac{2,054}{x},
$$

где $y-$ это скорость глобального макроэволюционного развития / темпы роста глобальной сложности, $x$ - это время до Сингулярности, а 2,054 - константа.

Конечно, $x$ (время до Сингулярности) на момент времени $t$ равняется $t^{*}-t$, где $t^{*}$ это дата
Сингулярности. Таким образом,

$$
x=t^{*}-t \text {. }
$$

С учетом данного обстоятельства уравнение (2) может быть переписано следующим образом:

$$
y_{t}=\frac{2,054}{t^{*}-t}
$$

где $y-$ это скорость глобального макроэволюционного развития / темпы роста глобальной сложности на момент времени $t, t *$ это дата Сингулярности, а 2,054 - константа.

Наконец, вспомним, что регрессионный анализ трансформированного временного ряда Модиса Курцвейла с использованием метода наименьших квадратов позволил нам идентифировать дату сингулярности как 2029 г. н.э. С учетом этого обстоятельства уравнение (3) может быть записано следующим образом:

$$
y_{t}=\frac{2,054}{2029-t}
$$

При этом, конечно, в общем виде эта модель имеет следующий вид:

$$
y_{t}=\frac{C}{t^{*}-t}
$$

где $C$ и $t^{*}-$ константы.

Несмотря на небольшое упрощение (в виде округления показателя степени в знаменателе до 1), уравнение (4) генерирует такие кривые, которые демонстрируют чрезвычайно высокое $\left(R^{2}\right.$ $=0,999(!))$ соответствие эмпирическим оценкам паттерна гиперболического ускорения роста глобальной сложности (см. ниже Рис. 13-15).

Кривая, сгенерированная этим чрезвычайно простым уравнением, описывает неожиданно точным образом паттерн гиперболического ускорения темпов планетарного макроэволюционного развития на протяжении миллиардов лет (см. Рис. 13). 


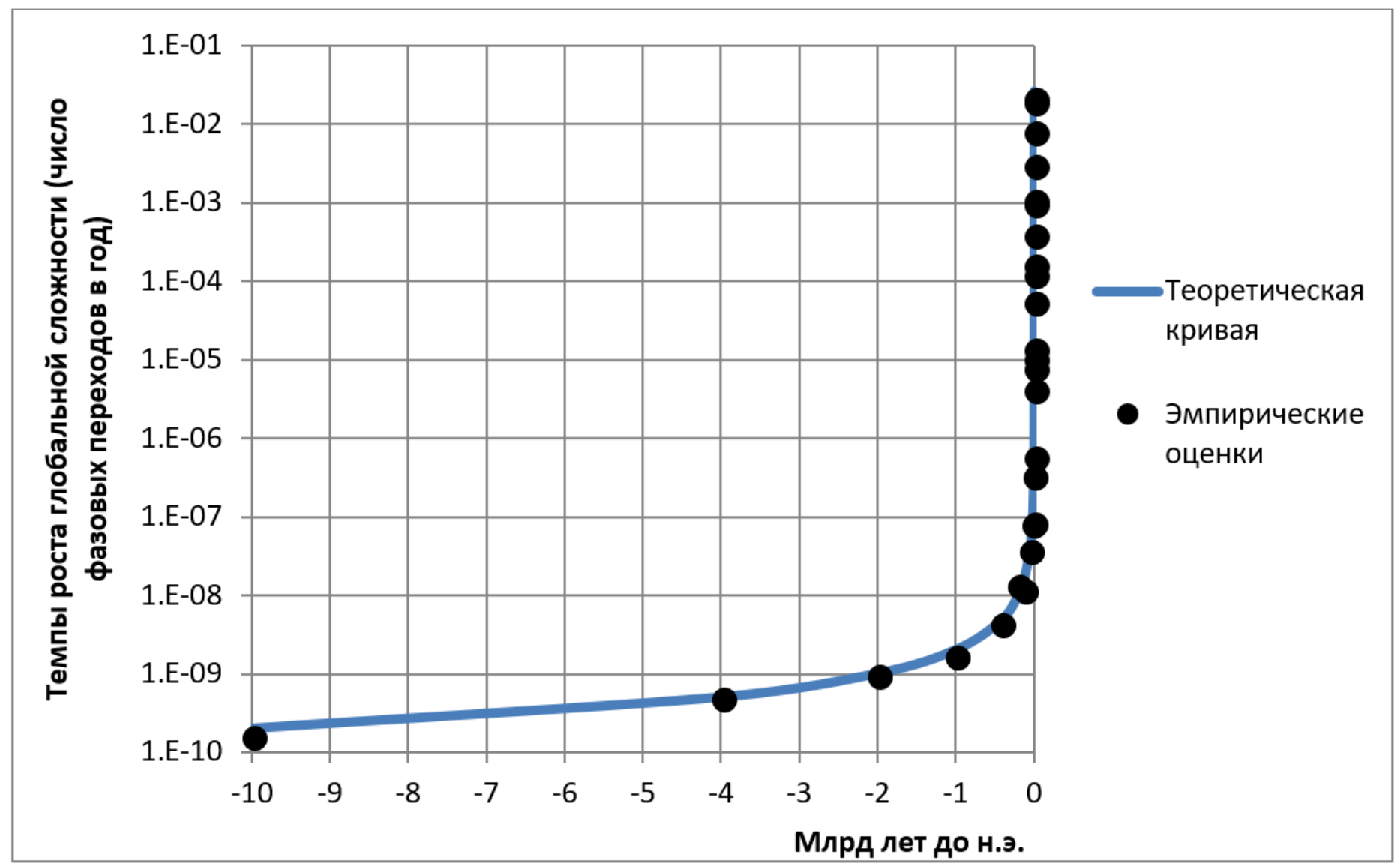

Рис. 13. Корреляция между эмпирическими оценками темпов роста глобальной сложности и теоретической кривой, сгенерированной гиперболическим уравнением $\mathrm{y}_{t}=2,054 /(2029-\mathrm{t}), 10$ млрд до н.э. - 2000 г. н.э., с логарифмической шкалой по оси ординат

Однако если мы рассмотрим Рис. 13 «под увеличением» для того, чтобы лучше увидеть последние два миллиарда лет, мы увидим, что уравнение (4), несмотря на свою чрезвычайную простоту, оказывается способным чрезвычайно точно описать гиперболическон ускорение темпов планетарного макроэволюционного развития и в этом масштабе времени (см. Рис. 14).

Если мы попробуем рассмотреть «под увеличением» и этот график - чтобы увидеть более детально ускорение глобального макроэволюционного развития за последние сотни тысяч лет Большой истории (что соответствует доистории и истории человечества), мы увидим столь же удивительно точное соответствие между гиперболической линией, генерируемой уравнением (4) и эмпирическим оценками темпов роста глобальной сложности (см. Рис. 15).

И, наконец, если мы сфокусируемся на последних тысячелетиях социальной фазы Большой истории, мы увидим, что и на этом участке то же самое уравнение описывает гиперболическое ускорение глобального макроэволюционного развития в высшей степени точно (см. Рис. 16).

Подчеркнемещераз, что кривая, удивительноточно описывающая ускорение человеческой истории после 10 тыс. до н.э. (Рис. 16), и кривая, столь же точно описывающая ускорение планетарного макроэволюционного развития до появления 


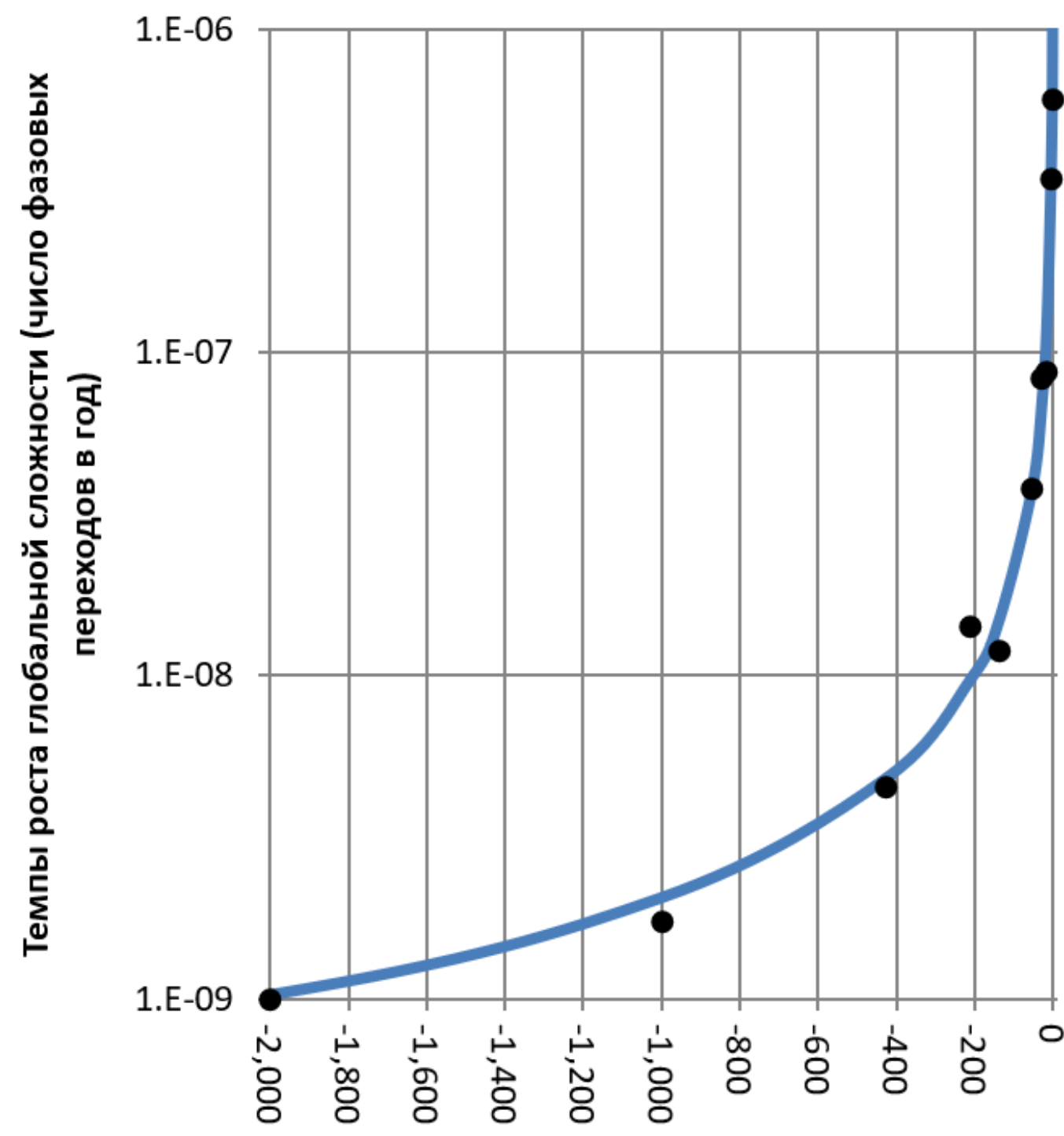

- Теоретическая кривая

- Эмпирические оценки

Миллионы лет до н.э.

Рис. 14. Корреляция между эмпирическими оценками темпов роста глобальной сложности и теоретической кривой, сгенерированной гиперболическим уравнением $y_{t}=2,054 /(2029-t), 2$ млрд до н.э. -2200000 г. до н.э., с логарифмической шкалой по оси ординат

человека (Рис. 14), сгенерирована одним и тем же уравнением - простейшим уравнением (4).

Как мы видим, простое гиперболическое уравнение $\mathrm{y}_{t}=2.054 /(2029-\mathrm{t})$ описывает наблюдавшееся до самого последнего времени ускорение темпов глобального макроэволюционного развития удивительно точным образом для всех основных эр глобальной истории.

Собственного говоря, модель (4) имеет достаточно простой «физический смысл». Действительно, подсчитаем скорость глобального макроэволюционного развития примерно за 


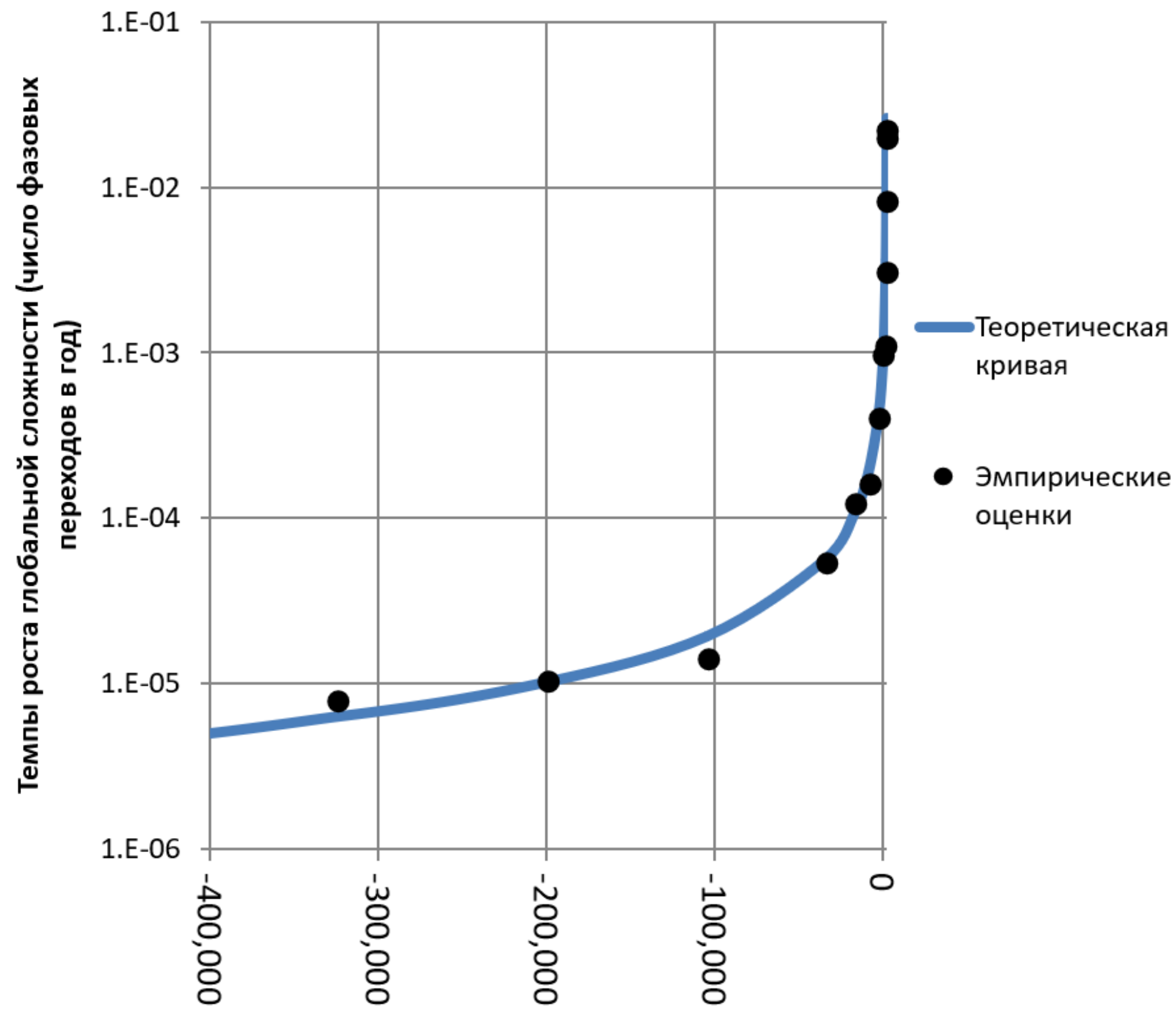

Рис. 15. Корреляция между эмпирическими оценками темпов роста глобальной сложности и теоретической кривой, сгенерированной гиперболическим уравнением $\mathrm{y}_{t}=2,054 /(2029-\mathrm{t}), 400000$ г. до н.э. -2000 г. н.э., с логарифмической шкалой по оси ординат

200 лет до Сингулярности (т.е. около 1829 г.), пользуясь еще более упрощеным видом уравнения (4) $\left(y_{t}=2 /(2029-t)\right): y_{1829}=2 /(2029-1829)=2 / 200$ $=1 / 100$. Мы таким образом получаем следующий результат: «около 1800 г. характерная скрость глобального макроэволюционного развития составляла порядка одного фазового перехода (типа Промышленной революции) за 100 лет»т.е. глобальное макроэволюционное развитие шло в масштабе веков.

Тот же самый подсчет для временной точки примерно за 2000 лет до Сингулярности ( $\approx$ до настоящего времени) - около 1 г. н.э., в районе 


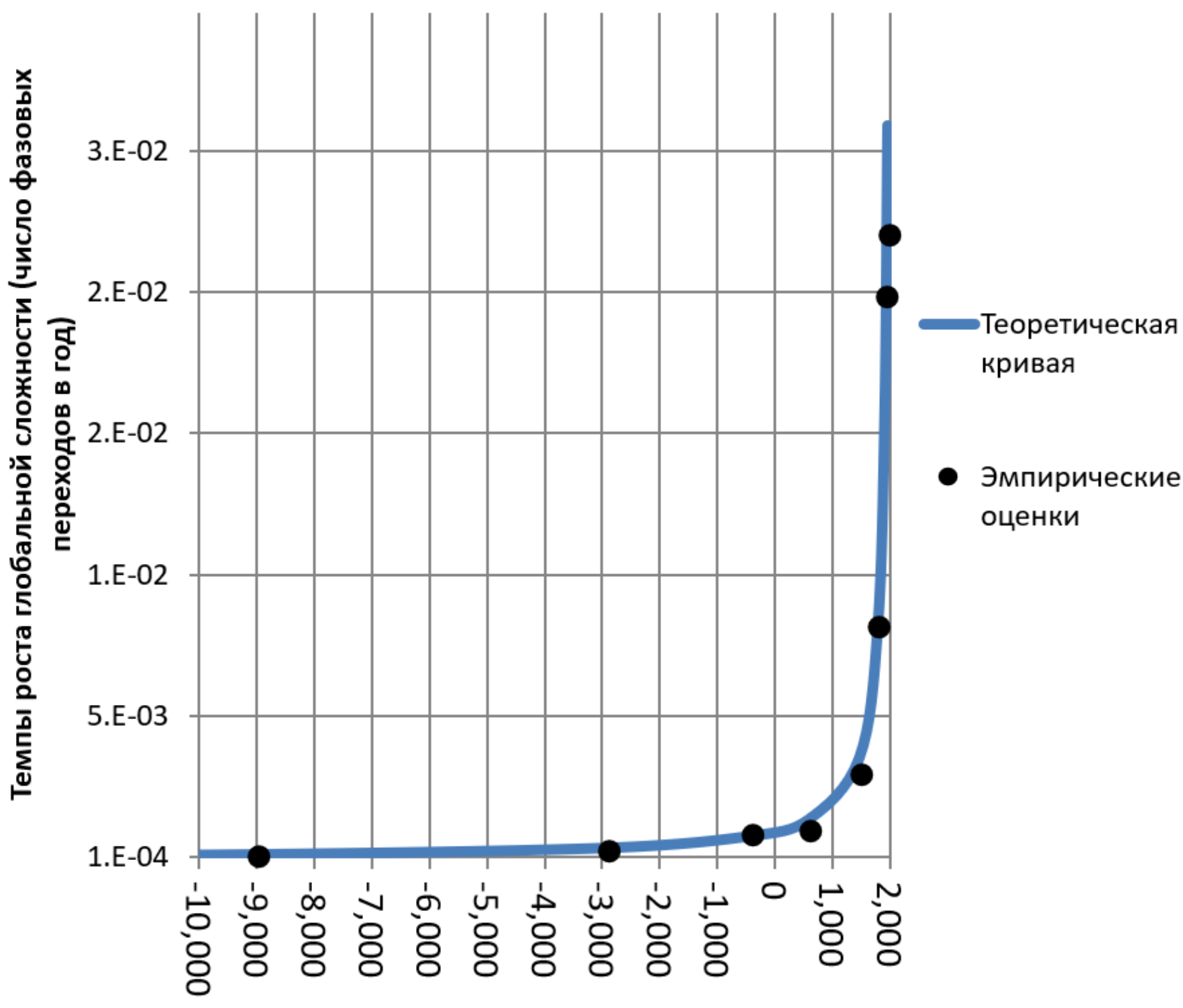

Рис. 16. Корреляция между эмпирическими оценками темпов роста глобальной сложности и теоретической кривой, сгенерированной гиперболическим уравнением $\mathrm{y}_{t}=2,054 /(2029-\mathrm{t}), 10000$ г. до н.э. - 2000 г. н.э., с натуральной шкалой по обеим осям 
29 г. даст следующий результат: $y_{29}=2 /(2029-29)$ $=2 / 2000=1 / 1000-$ таким образом, в эту эпоху макроэволюционные фазовые переходы (типа фазового перехода Осевого времени) имели тенденцию происходить в масштабе один переход за тысячелетие, т.е. в масштабетысячелетий. Таким образом, в районе 18 тыс. до н.э. мы обнаружим, что планетарное макроэволюционное развитие шло в масштабе десятков тысяч лет, около 200 тыс. лет до настоящего времени - в масштабе сотен тысяч лет (около одного фазового перехода за сто тысяч лет), около 2 млн лет назад - в масштабе миллионов лет, около 20 млн лет назад - в масштабе десятков миллионов лет, около 200 млн лет назад - в масштабе сотен миллионов лет, а около 2 млрд лет назад - в масштабе миллиардов лет (т.е., около одного планетарного макроэволюционного фазового перехода за миллиард лет). Другими словами, с каждым уменьшением времени до настоящего момента ( $\approx$ до «Сингулярности») на порядок (с 2 млрд лет назад до 200 млн лет назад, с 200 млн лет назад до 20 млн лет назад, с 20 млн лет назад до 2 млн лет назад, и т.д.) темпы глобального макроэволюционного развития ( темпы роста глобальной сложности) всякий раз увеличивались именно на порядок. И лично мне такой паттерн ускорения представляется очень похожим на реально наблюдавшийся.

Здесь также стоит вспомнить, что алгебраическое уравнение типа

$$
y_{t}=\frac{C}{t^{*}-t}
$$

может рассматриваться как решение следующего дифференциального уравнения:

$$
\frac{d y}{d t}=\frac{y^{2}}{C}
$$

(см., например, Korotayev, Malkov, Khaltourina 2006a: 118-120).

Таким образом, формула ускорения, подразумеваемая уравнением (4) может быть выражена следующим образом:

$$
\frac{d y}{d t}=\frac{y^{2}}{2.054} \approx 0.5 y^{2} \text {. }
$$

Вербально общая формула ускорения планетарной макроэволюции, которая столь точно описывает ряд «скачков [в уровне] сложности» ${ }^{12}$ Модиса Курцвейла при помощи уравнений (4) / (5), может быть сформулирована следующим образом: "увеличениетемповмакроэволюционногоразвития в $a$ раз сопровождается увеличением скорости роста (т.е. ускорения) темпов макроэволюционного развития в $a^{2}$ раз; так, двукратное увеличение темпов макроэволюционного развития в тенденции сопровождается четырехкратным увеличением скорости роста (т.е. ускорения) темпов макроэволюционного развития; десятикратное увеличение темпов макроэволюционного развития в тенденции сопровождается стократным ускорением роста темпов макроэволюционного развития; и т.д. ...”.

Теперь используем ту же самую методику для формального анализа временно́го ряда глобальных макроэволюционных «фазовых переходов» / «биосферных революций», идентифицированного А. Д. Пановым (Панов 2004, 2005, 2006, 2008; 2005a, 2005b; Panov 2005, 2011, 2017).

Однако прежде, чем мы проведем этот анализ, представляется целесообразным разобрать несколько существенных моментов.

\section{Временные ряды Т. Модиса - Р. Курцвейла и А. Д. Панова: внешний сравнительный анализ}

Т. Модис и А. Д. Панов провели идентификацию своих временных рядов полностью независимо

12 Именно так (не без некоторых оснований) называет Т. Модис (Modis 2002, 2003) то, что А. Д. Панов обозначает как «биосферные революции» или «фазовые переходы». 
друг от друга. Как свидетельствует мое личное общение как с А. Д. Пановым, так и Т. Модисом, ни один из них даже не догадывался, что в практически то же самое время ${ }^{13}$ на другом конце Европы другой человек занимался идентификацией очень похожего временного ряда (А. Д. Панов работал и работает в Москве, а Т. Модис - в Женеве). Как мы увидим ниже, они опирались на совершенно различные источники; и неудивительно, что полученные ими временные ряды оказались совсем не идентичными.

Действительно, временной ряд Т. Модиса (Modis 2003), который стоит за курцвейловским графиком «Канонические вехи» (Kurzweil 2005: 20), выглядит следующим образом (мы воспроизводим его ниже в том виде, как он был опубликован Модисом в своем эссе в научно-популярном журнале Futurist (Modis 2003), так как именно на эту версию ряда опирался Р. Курцвейл при создании его графика и именно эта версия ряда была выше проанализирована математически; мы, однако, время от времени уточняем некоторые детали по более академическому описанию данного ряда из статьи Т. Модиса, опубликованной в 2002 г. в научном журнале Technological Forecasting \& Social Change (Modis 2002)):

(1) Возникновение Млечного пути, первые звезды - 10 млрд лет назад. ${ }^{14}$

(2) Возникновение жизни на Земле, формирование Солнечной системы и Земли, древнейшие скалы - 4 млрд лет назад.

(3) Появление эвкариотов, изобретение

13 Т. Модис впервые представил свои результаты в 2002 в своей статье в журнале Technological Forecasting and Social Change (эту статью А. Д. Панов прочитал только в марте 2018 года, после того, как она была послана мной Панову), в то время как еще в 2003 году Панов представил свои результаты в Москве на семинаре Государственного астрономического института.

14 Собственно говоря, Модис начинает с Большого взрыва, но Курцвейл вполне обоснованно предпочитает начать с формирования Млечного пути. полового размножения (микроорганизмами), атмосферный кислород, древнейшие фотосинтезирующие растения, возникновение тектоники плит - 2 млрд лет назад.

(4) Первые многоклеточные, губки, водоросли, протисты -1 млрд лет назад.

(5) Кембрийский взрыв/беспозвоночные/ позвоночные, растения колонизируют сушу, первые деревья, рептилии, насекомые, амфибии - 430 млн лет назад.

(6) Первые млекопитающие, первые птицы, первые динозавры - 210 млн лет назад.

(7) Первые покрытосеменные, древнейшие остатки цветковых растений - 139 млн лет назад.

(8) Первые приматы / столкновение с астероидом / mass extinction (including dinosaurs) - 54,6 млн лет назад.

(9) Первые человекообразные обезьяны, первые гоминиды - 28,5 млн лет назад.

(10) Первый орангутан, проконсул - 16,5 млн лет назад.

(11) Расхождение предков шимпанзе и человека, самый ранние свидетельства прямохождения у гоминид - 5,1 млн лет назад.

(12) Первые каменные орудия, Homo erectus - 2,2 млн лет назад.

(13) Возникновение Homo sapiens - 555000 лет назад.

(14) Доместикация огня / Homo heidelbergensis 325000 лет назад.

(15) Расхождение типов человеческой ДНК 200000 лет назад.

(16) Люди современного вида / древнейшие погребения - 105700 лет назад.

(17) Наскальное искусство, протописьмо - 35800 лет назад.

(18) Технология добывания огня - 19200 years ago. (19) Появление земледелия - 11000 years ago ${ }^{15}$.

15 Более популярная версия презентации результатов Модиса (Modis 2003) содержит явную опечатку (указывая 19200 лет назад как дату начала неолитической революции). Эта опечатка отсутствует в более академической версии презентации результатов Модиса (Modis 2002), на которую 
(20) Изобретение колеса / письмо / древние империи / большие цивилизации / Египет / Месопотамия - 4907 лет назад.

(21) Демократия/города-государства /древние греки/Будда [ح Осевое время] - 2437 лет назад.

(22) Изобретение нуля и десятичного исчисления, падение Рима, исламские завоевания - 1440 лет назад.

(23) Ренессанс (книгопечатание) / открытие Нового Света / научный метод - 539 лет назад.

(24) Промышленная революция (паровой двигатель)/политические революции (Франция, США) - 225 лет назад.

(25) Современная физика / радио / электричество / автомобиль / аэроплан - 100 лет назад.

(26) Дешифровка структуры ДНК / изобретение транзистора / ядерная энергия / II Мировая война / холодная война / Спутник - 50 лет назад.

(27) Интернет / расшировка генома человека - 5 лет назад.

* Отметим, что сам Модис вполне ясно заявляет, что «настоящее время приравнивается здесь к 2000 г. н.э.» (Modis 2003: 31). Действительно, это имеет вне всякого сомнения смысл по отношению к «вехам» (24)-(27) из списка Модиса - Курцвейла. С другой стороны, имеются некоторые основания предполагать, что Модис начал составлять первые варианты своего списка за несколько лет до 2000 года и, по всей видимости, не привел в своей публикации 2003 года некоторые старые датировки «вех» в соответствие с новой условной датой «настоящего времени», установленной на точку 2000 г. н.э. Иначе трудно понять датировки им вех (20), (21) и (23).

T. Модис (Modis 2002: 393-401) дает следующий список научных публикаций, на которые он опирался при идентификации своего временно́го ряда: Barrow, Silk 1980; Burenhult 1993; Heidmann 1989; Johanson, Edgar 1996; Sagan 1989; Schopf $1991^{16}$.

мы в данном случае и опираемся.

16 К этому он также добавляет стенд "Timeline of the Universe" Американского музея естественной истории
А. Д. Панов при идентификации своего временно́го ряда опирался на абсолютно другие публикации ${ }^{17}$ (см. Таблицу 1):

Как мы видим, нет ни одной публикации, на которую опирались бы одновременно и Т. Модис (Modis 2002, 2003), и А. Д. Панов (2004, 2005), когда они составляли свои списки «канонических вех / биосферных революций». Списки использованных ими источников различаются на $100 \%$. Более того, они в основном опирались на источники, принадлежащие к разным научным традициям. Действительно, Модис опирался исключительно

(American Museum of Natural History, Central Park West at 79th Street, New York), Encyclopedia Britannica (без точных библиографических ссылок на конкретные статьи), "the web site of the Educational Resources in Astronomy and Planetary Science (ERAPS), University of Arizona" (без указания точного URL), "Private communication, Paul D. Boyer, Biochemist. Nobel Prize 1997. Dec 27, 2000" и "а timeline for major events in the history of life on earth as given by David R. Nelson, Department of Biochemistry at the University of Memphis, Tennessee" (http://drnelson.utmem.edu/evolution2.html).

17 По крайней мере при составлении своего первого списка «фазовых переходов/биосферных революций» на русском языке (Панов 2004, 2005). Отметим, что при подготовке публикации своих результатов на английском языке Панов (Panov 2005) добавил к своей почти полностью русскоязычной библиографии 8 публикаций на английском языке (Begun 2003; Carrol 1988; Jones 1994; Nazaretian 2003; A.H. 1975; А.P. 1975; J.B.W. 1975; Т.К. 1975) и 1 публикацию на немецком языке (Jaspers 1955). Нельзя полностью исключить того, что это могло как-то повлиять на датировку Пановым некоторых из его «биосферных революций» (действительно, можно найти некоторые [очень, впрочем, небольшие] различия в датировках между публикациями 2005 года на русском [Панов 2005] и английском [Panov 2005] языке). Отметим также, что эти англоязычные публикации включают в себя четыре статьи из Encyclopedia Britanica, что сделало список источников в англоязычной статье Панова (Panov 2005) уже не столь абсолютно отличным от модисовского списка, как это наблядалось для русскоязычной статьи (Панов 2005) (так как Модис также включил Encyclopedia Britanica в список своих источников). Поэтому «для чистоты эксперимента» мы решили для наших вычислений опираться на пановский список «фазовых переходов / биосферных революций», представленный в его русскоязычной (Панов 2005), а не англоязычной (Panov 2005) статье. 
Источники, использованные T. Модисом для идентификации списка фазовых переходов / «скачков сложности», опубликованного в Modis 2002, 2003

(1) Barrow, Silk 1980;

(2) Burenhult 1993;

(3) Heidmann 1989;

(4) Johanson, Edgar 1996;

(5) Sagan 1989; (6) Schopf 1991; к этому списку Т. Модис добавляет:

(7) "Timeline of the Universe" (American Museum of Natural History, Central Park West at 79th Street, New York),

(8) Encyclopedia Britannica, (9) "the web site of the Educational Resources in Astronomy and Planetary Science (ERAPS), University of Arizona", (10) "Private communication, Paul D. Boyer, Biochemist. Nobel Prize 1997. Dec 27, 2000", (11) "a timeline for major events in the history of life on earth as given by David R. Nelson, Department of Biochemistry at the University of Memphis, Tennessee" (http://drnelson.utmem. edu/evolution2.html)
Источники, использованные А. Д. Пановым для идентификации списка фазовых переходов / «биосферных революций», опубликованного в первой полностью академической публикации его результатов (Панов 2005)

Работы российских ученых, опубликованные на русском языке:

(1) Борисковский 1970, (2) Борисковский 1974a, (3) Борисковский 1974б, (4) Борисковский 1978; (5) Дьяконов 1994; (6) Федонкин 2003; (7) Галимов 2001; (8) Капица 1996; (9) Келлер; (10) Лопатин 1983; (11) Муратов, Вахрамеев 1974; (12) Назаретян 2004; (13) Розанов 1986; (14) Розанов 2003; (15) Розанов, Заварзин 1997; (16) Шанцер 1973; (17) Заварзин 2003; (18) Зайцев 2001.

Работы западных ученых, переведенные на русский язык:

(1) Антисери, Реале 2001; (2) Биган 2004; (3) Кэррол 1992, (4) Кэррол 1993а, (5) Кэррол 1993б; (6) Фоули 1990; (7) Ясперс 1991; (8) Кринг, Дурда 2004; (9) Вонг 2003.

Оригинальные публикации западных ученых на английском языке:

(1) Alvarez et al. 1980; (2) Orgel 1998; (3) Wood 1992.

Таблица 1. Сопоставление источников, использованных Т. Модисом (Modis 2002, $2003)$ и А. Д. Пановым (2005) для составления их списков «фазовых переходов» / «биосферных революций» / «канонических вех» / «эволюционных поворотных точек» / «скачков сложности» 
на работы западных ученых, опубликованные на английском языке ${ }^{18}$. В разительном контрасте с этим, из 30 источников, использованных Пановым (2005), 18 представляют собой работы российских исследователей, опубликованных в России на русском языке; 9 - это работы западных ученых, переведенные на русский язык и опубликованные в России; и лишь 3 - это оригинальные работы западных исследователей на английском языке.

\section{В свете этого вряд ли у кого-то вызовет удивление} то, что пановский список фазовых переходов (Панов 2005: 124-127) оказался ни в коем случае не идентичным модисовскому ${ }^{19}$ :

«0. Возникновение жизни на Земле - около 4 х $10^{9}$ лет назад (Orgel 1998; Розанов, Заварзин 1997; Розанов 2003; Федонкин 2003). Жизнь возникает в форме примитивных безъядерных одноклеточных организмов - прокариотов (и, возможно, вирусов [Галимов, 2001]). После возникновения жизни, приблизительно в течение 2 - 2,5 млрд. лет эволюция протекала, повидимому, без существенных потрясений, при этом главным системообразующим фактором биосферы была прокариотная фауна. Это видно, в частности, по монотонному росту скорости отложения горючих ископаемых (седиментогенез) вплоть до достижения максимума 2,0 - 1,5 млрд. лет назад [Лопатин, 1983]. Однако задолго до конца прокариотной эры возникли первые эвкариоты и, возможно, даже примитивные многоклеточные организмы [Розанов, 2003; Федонкин, 2003]. Специально отмечается [Федонкин, 2003], что эвкариоты не играли заметной роли в глобальных биохимических циклах вплоть до кислородного кризиса около 1,5 млрд. лет назад (см. ниже). Эвкариотная фауна на фоне прокариотной

18 Впрочем, один из его источников (Heidmann 1989) представляет собой перевод на английский язык книги, изначально опубликованной на французском.

19 Отметим, что в тех случаях, когда А. Д. Панов (2005) указывает временные интервалы, а не точные даты, мы для своих расчетов использовали средние значения соответствующих интервалов; например, Панов (2005) в качестве даты «биосферной революции 5» («Начало неогена») 25-20 • $10^{6}$ лет назад, в то время как мы для своих расчетов используем среднее значение соответствующего интервала (т.е. 22,5 • $10^{6}$ лет назад). существовала в форме избыточного внутреннего разнообразия.

1. Кислородный кризис или неопротерозойская революция - 1,5 х $10^{9}$ лет назад [Федонкин, 2003; Лопатин, 1983; Розанов, 2003; Заварзин, 2003]. Цианобактерии обогатили первоначально восстановительную атмосферу Земли кислородом, который был сильным ядом для анаэробных прокариотов. Анаэробные организмы стали вымирать, что видно, в частности, по резкому замедлению седиментогенеза в этот период [Лопатин, 1983; Розанов, Заварзин, 1997]. Кислородный кризис - типичный пример эндоэкзогенного кризиса и первый глобальный экологический кризис в истории Земли. На смену анаэробным прокариотам пришли аэробные формы жизни, которые представлены в основном как одноклеточными, так и многоклеточными эквариотами. По разным данным это событие имело место от 2,0 до 1,0 млрд. лет назад, но при этом фактически имеются в виду разные фазы этого перехода. От пика революции нас отделяет приблизительно 1,5 млрд лет.

2. Кембрийский взрыв - 590 - 510 х $10^{6}$ лет назад [Келлер, 1975; Розанов, 1986; Кэррол, 1992]. В течение нескольких десятков миллионов лет возникают практически все современные филогенетические стволы многоклеточных, включая позвоночных [Кэррол, 1992, с. 37]. Кембрийский взрыв совпадает с началом палеозойской эры. В течение палеозоя жизнь постепенно выходила на сушу и осваивала ее. Уже в кембрии обнаружены первые попытки выхода беспозвоночных на сушу [Федонкин, 2003]. Палеозойская эра заканчивается господством на суше земноводных, чрезвычайно разнообразных и часто гигантских [Кэррол, 1992], среди растений - хвощи, плауны и папоротники. За несколько десятков миллионов лет до окончания палеозоя возникают первые пресмыкающиеся (избыточное разнообразие), которые становятся системообразующим фактором следующей фазы развития планетарной системы.

3. Начало мезозойской эры, революция пресмыкающихся - 235 х 106 лет назад [Кэррол, 1992; Муратов, Вахрамеев, 1974; Кэррол, 1993а ]. Внезапно и быстро вымирают практически все отряды палеозойских земноводных [Кэррол, 1992, с. 192], 
лидерство на суше переходит к пресмыкающимся - сначала звероподобным и зверозубым ящерам, потом к динозаврам [Кэррол, 1993a ]. В мире растений начинают господствовать голосемянные (хвойные, гинковые и др.). Уже в середине мезозоя появляются первые млекопитающие, но в экосистемах они играют подчиненную роль (избыточное многообразие).

4. Начало кайнозойской эры, революция млекопитающих - 66 х $10^{6}$ лет назад [Шанцер, 1973; Кэррол, 1993а; 19936 ]. Полностью вымирают динозавры, на суше - гигантский всплеск разнообразия млекопитающих, в воздухе господствуют птицы, среди растений голосемянные вытесняются покрытосемянными (цветковыми). Предположение о том, что вымирание динозавров вызвано исключительно последствиями падения гигантского метеорита, образовавшего кратер Чикулуб [Alvares, 1980; Кринг, Дурда, 2004], вызывает серьезную критику, так как вымирание динозавров длилось 1 - 2 млн лет, а пыль и сажа могли держаться в атмосфере максимум несколько месяцев [Кэррол, 1993a ], при этом длительных глобальных климатических изменений не отмечается.

5. Начало неогена - 25 - 20 × $10^{6}$ лет назад [Шанцер, 1973; Кэррол, 1993б; Биган, 2004]-сопровождается резким обновлением фауны на территории Европы; флора и фауна приобретают практически современный вид. Возникают гоминоиды - человекообразные обезьяны, причем это событие имеет характер сильнейшего эволюционного взрыва. Между 22 и 17 млн. лет назад Африку населяли не менее 14 родов гоминоидов, что составляет десятки видов [Биган, 2004] (много больше, чем сейчас).

6. Начало четвертичного периода (антропоген) - 4,4 х $10^{6}$ лет назад [Биган, 2004; Фоули, 1990; Wood, 1992]. Первые примитивные люди (гоминиды) отделяются от обезьяноподобных (гоминоидов). Подобно началу неогена, начало антропогена сопровождалось всплеском разнообразия Homo [Wood, 1992]. Далее следует несколько событий, имеющих, возможно, не столько биологический, сколько социальный характер (см. обсуждение в конце данного раздела). Периоды различаются по характеру обработки орудий труда людьми каменного века. Существующая традиция, отраженная и в энциклопедиях, выделяет последовательность эпох Олдувай - Шелль - Ашель - Мустье.

7. Олдувай, палеолитическая революция - 2,0 - 1,6 х $10^{6}$ лет назад [Борисковский, 1974а ]. Появление первых очень грубо обработанных каменных орудий труда - так называемых чопперов. Галечные культуры, Homo habilis.

8. Шелль - 0,7 - 0,6 х $10^{6}$ лет назад [Борисковский, 1978]. Овладение огнем, топоровидные орудия с поперечным лезвием (кливеры), грубые рубила. Основной носитель культуры - Homo erectus.

9. Ашель - 0,4 х $10^{6}$ лет назад [Борисковский 1970] - характеризуется стандартизированными овальными, треугольными, круглыми и другими симметричными рубилами. Основной представитель по-прежнему Homo erectus. На фоне ашельской культуры появляется неандерталец (Homo sapiens neandertalensis) [Борисковсий 1970] и около 160 тыс. лет назад Homo sapiens sapiens или очень близкий вид [Вонг, 2003]. Однако, по-видимому, ни тот, ни другой не играют пока существенной роли в планетарной системе (избыточное разнообразие).

10. Мустье(культурнаяреволюциянеандертальцев)- 150 - 100 тыс. лет назад [Назаретян, 2004; Борисковский, 19746 ]. Лидером планетарной системы становится неандерталец. Каменные и костяные орудия тонкой обработки - скребла, остроконечники, сверла, ножи. Жилища из костей мамонта и шкур. Захоронение мертвых (примитивные религии). Homo sapiens sapiens по-прежнему не имеет существенного значения в планетарной системе [Назаретян, 2004].

11. Верхнепалеолитическая революция (культурная революция кроманьонцев) - 40 тыс. лет назад [Назаретян,2004; Дьяконов, 1995]. Вымирают неандертальцы, носителем культуры становится человек современного вида Homo sapiens sapiens. Многократно возросла продуктивность использования каменного сырья, заметно усовершенствовались знаковые системы коммуникации. Значительное развитие охотничьей автоматики (копья, ловушки), широкое распространение искусства (наскальные рисунки).

12. Неолитическая революция - 12 - 9 тыс. лет назад [Назаретян, 2004; Дьяконов, 1995]. В конце верхнего палеолита развитие охотничьих технологий привело к истреблению популяций и целых видов животных, что подорвало пищевые ресурсы палеолитического 
общества и привело к ужесточению межплеменной конкуренции. Ответом на кризис был переход от присваивающего (охота, собирательство) к производящему (земледелие, скотоводство) хозяйству и смена нормативного геноцида зачаточными формами коллективной эксплуатации [Назаретян, 2004]. Уже в неолите появляются предки городов, такие как Чатал-Хююка (VII-VI тыс. до н.э.), Иерихон (VII тыс. до н.э.) [Дьяконов, 1995]. Однако на этом этапе они еще не являются существенным системообразующим фактором [Дьяконов, 1995].

13. Городская революция, начало древнего мира - IVIII тыс. до н.э. [Назаретян, 2004; Дьяконов, 1995]. Массовое распространение крупных человеческих агломераций, возникновение письменности, первых правовых документов, настоящей бюрократии и классового общества, появление ремесел. Революция последовала за распространением бронзовых орудий, демографическим взрывом и обострением конкуренции за плодородные земли.

14. Железный век, эпоха империй, революция Осевого времени- 800-500лет дон.э. [Ясперс, 1991;Назаретян, 2004; Дьяконов, 1995; Зайцев, 2001]. Возникновение технологии получения железа около 1000 - 900 лет до н.э. привело к тому, что оружие стало намного более дешевым, легким, эффективным, а войны более кровопролитными. Ответом на этот кризис техногуманитарного баланса было, во-первых, объединение мелких государств в более крупные образования - империи, и, во-вторых, авторитарное мифологическое мышление стало вытесняться личностным. Личность начала восприниматься как суверенный носитель морального выбора. Это привело к практически одновременному появлению в разных местах Земли мыслителей и полководцев нового типа - Заратустра, иудейские пророки, Сократ, Будда, Конфуций [Ясперс, 1991] и др. - и к культурному взрыву античности [Зайцев, 2001].

15. Гибель древнего мира, начало средневековья - 400 - 630 гг. (здесь и далее новой эры) [Дьяконов, 1995]. Начало перехода я условно связываю с деятельностью Святого Августина и осуждением пелагианства на Карфагенском соборе в 417 г., что означало конец эллинистической философии [Антисери, Реале, 2001], а конец перехода - с деятельностью пророка Мухаммеда (570 - 632).
Основное содержание перехода состоит в кризисе и гибели Римской империи (Древнего мира) с последующим распространением феодальных государств и княжеств под ведущей ролью мировых тоталитарных религий (но, конечно, не сводится только к этому).

16. Первая промышленная революция - 1450 - 1550 гг. [Капица, 1996; Назаретян, 2004; Дьяконов, 1995]. В терминологии И. Дьяконова - начало стабильноабсолютистского постсредневековья [Дьяконов, 1995]. Возникновение промышленного производства (мануфактуры), великие географические открытия, возникновение книгопечатания и культурный переворот нового времени.

17. Вторая промышленная революция - 1830 - 1840 гг. [Капица, 1996; Дьяконов, 1995]. Возникновение механизированного производства, эпоха пара и электричества. Начало глобализации в области информации - в 1831 г. изобретен телеграф. В культурной области начинает формироваться устойчивое негативное отношение к войне как к средству решения политических вопросов (Л. Толстой и др.).

18. Информационная революция - 1950 г. [Капица, 1996; Назаретян, 2004; Дьяконов, 1995]. Переход промышленноразвитых странвпостиндустриальную эпоху, когда большая часть населения занята не в материальном производстве, а в сфере обслуживания и в переработке информации. Распространение компьютеров и автоматизированных баз данных. Войны между промышленно развитыми супердержавами вытесняются в виртуальную область, принимая форму холодной войны (изменение уровня техногуманитарного баланса).

19. Кризис и распад социалистического лагеря, информационная глобализация - 1991 г. Распад мировой системы тоталитарной плановой экономики, резкое снижение уровня глобального военного противостояния, становление мировой сети Интернет, означающеезавершениеинформационной глобализации. Данные события пока отнюдь не всегда трактуются как революция, но, как будет видно, по некоторым чисто формальным признакам они имеют тот же статус, что и предыдущие» (Панов 2005: 124-127).

Отметим, что последняя точка данных (19) 
отсутствует на приводимых ниже графиках, но она была использована для оценки скорости глобального макроэволюционного развития для точки данных (18).

В свете вышеописанного радикального различия в источниковых базах Модиса и Панова, а также полной независимости проводившихся ими исследований друг от друга, вряд ли может вызвать удивление то, что пановский список «биосферных революций» очень значительно отличается от ряда «канонических вех» Модиса - Курцвейла:
1) список Модиса - Курцвейла содержит 27 “канонических вех”, в то время как пановский ряд включает лишь 20 «биосферных революций». Таким образом, как минимум 7 вех Модиса - Курцвейла не имеют никаких параллелей в ряду Панова.

2) Есть лишь одна «веха», для которой и Модис, и Панов имеют полностью идентичные название и датировку (Модис - Курцвейл 2 = Панов 0). Имеется также одна веха (Модис - Курцвейл 26 $=$ Панов 18), которую Модис и Панов датируют

\begin{tabular}{|c|c|}
\hline Ряд Модиса - Курцвейла & Ряд Панова (2005) \\
\hline $\begin{array}{l}\text { (6) Первые млекопитающие, первые птицы, } \\
\text { первые динозавры - } 210 \text { млн лет назад. } \\
\text { (7) Первые покрытосеменные, древнейшие } \\
\text { остатки цветковых растений - } 139 \text { млн лет назад. } \\
\text { (8) Первые приматы / столкновение с } \\
\text { астероидом / mass extinction (including dinosaurs) } \\
\text { - 54,6 млн лет назад. } \\
\text { (9) Первые человекообразные обезьяны, } \\
\text { первые гоминиды - } 28,5 \text { млн лет назад. } \\
\text { (10) Первый орангутан, проконсул - 16,5 млн } \\
\text { лет назад. } \\
\text { (11) Расхождение предков шимпанзе и челове- } \\
\text { ка, самый ранние свидетельства прямохождения } \\
\text { у гоминид - 5, } 1 \text { млн лет назад. } \\
\text { (12) Первые каменные орудия, Hoто erectus - } \\
\text { 2,2 млн лет назад. } \\
\text { (13) Возникновение Ното sapiens - } 555 \text { 000 лет } \\
\text { назад. } \\
\text { (14) Доместикация огня / Homo heidelbergensis } \\
\text { - 325 } 000 \text { лет назад. } \\
\text { (15) Расхождение типов человеческой днк - } \\
\text { 200 } 000 \text { лет назад. }\end{array}$ & $\begin{array}{l}\text { (3) Начало мезозойской эры, революция } \\
\text { пресмыкающихся - } 235 \text { млн лет назад. } \\
\text { (4) Начало кайнозойской эры, революция } \\
\text { млекопитающих - } 66 \text { млн лет назад. } \\
\text { (5) Начало неогена - 25-20 млн лет назад. } \\
\text { (6) Начало четвертичного периода (антропоген) - } \\
\text { 4,4 млн лет назад. } \\
\text { (7) Олдувай, палеолитическая революция - 2,0-1,6 } \\
\text { млн лет назад. } \\
\text { (8) Шелль - } 600-700 \text { тыс. лет назад. } \\
\text { (9) Ашель - } 400 \text { тыс. лет назад. }\end{array}$ \\
\hline
\end{tabular}

Таблица 2. Корреляция между списками фазовых переходов Модиса и Панова для периода между 400 млн лет назад и 150 тыс. лет назад 


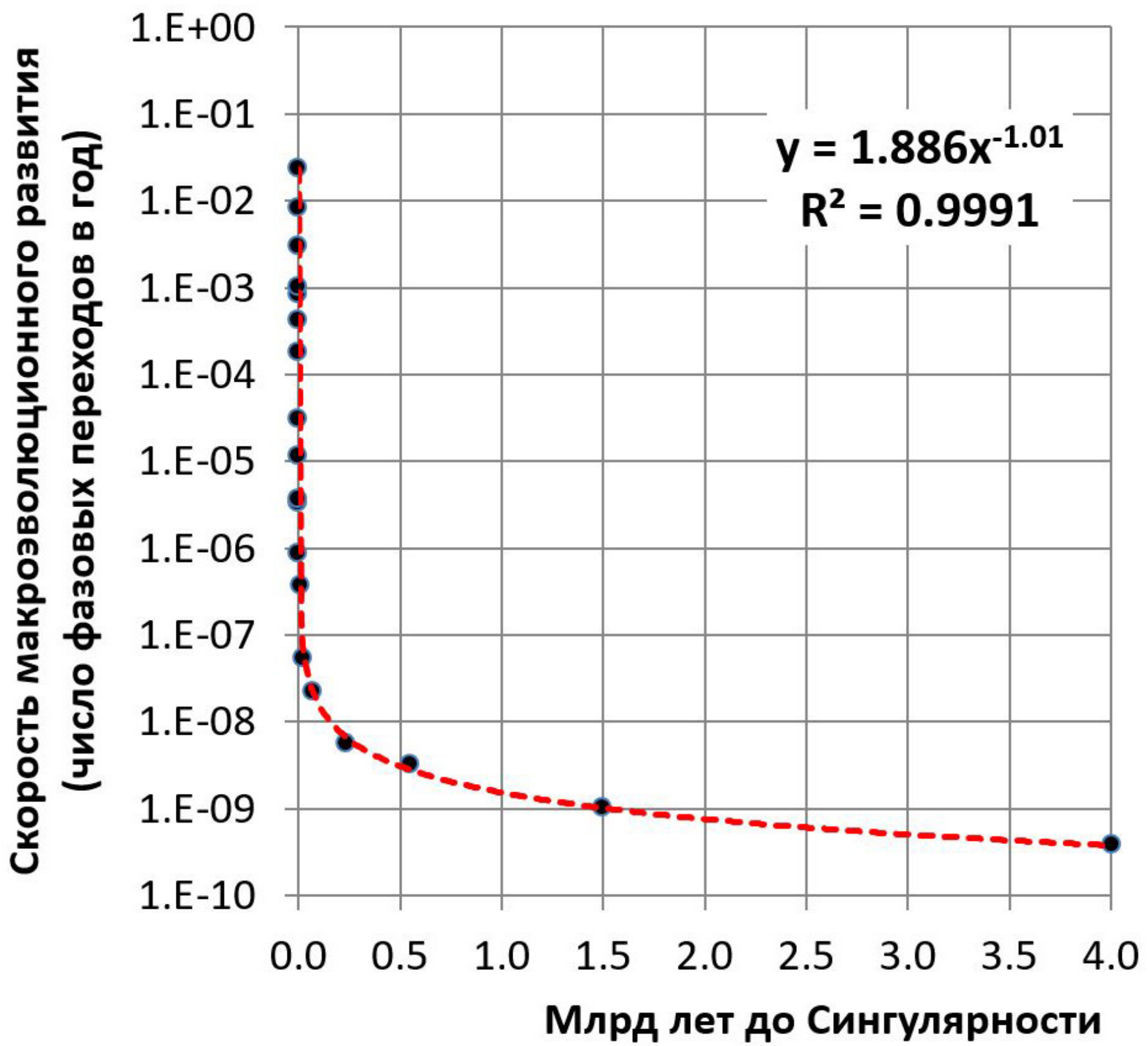

Рис. 17. Диаграмма рассеивания точек фазовых переходов Панова с наложенной линией степенной регрессии (с логарифмическрй шкалой по оси ординат) - для определенной методом наименьших квадратов даты Сингулярности 2027 г. н.э. 
одинаково, но которой они дают совершенно различные названия.

3) Имеется несколько вех, которым Модис и Панов дают отдаленно сходные названия и примерно (но не в точности) сходные датировки (например, Модис - Курцвейл $23 \approx$ Панов 16; Модис - Курцвейл $19 \approx$ Панов 12; Модис Курцвейл $17 \approx$ Панов 11 ; Модис - Курцвейл $9 \approx$ Панов 5). В одном случае Модис и Панов дают одной и той же вехе (Модис - Курцвейл 5 Панов 2) одинаковое название, но очень разные даты.

4) С другой стороны, для очень значительных отрезков рассматриваемых рядов корреляция между ними выглядит крайне удаленной. Например, для периода между 400 млн лет назад и 150 тыс. лет назад эта корреляция выглядит следующим образом (см. Таблицу 2):

Как мы видим, для очень большой части планетарной истории (между Кембрийским

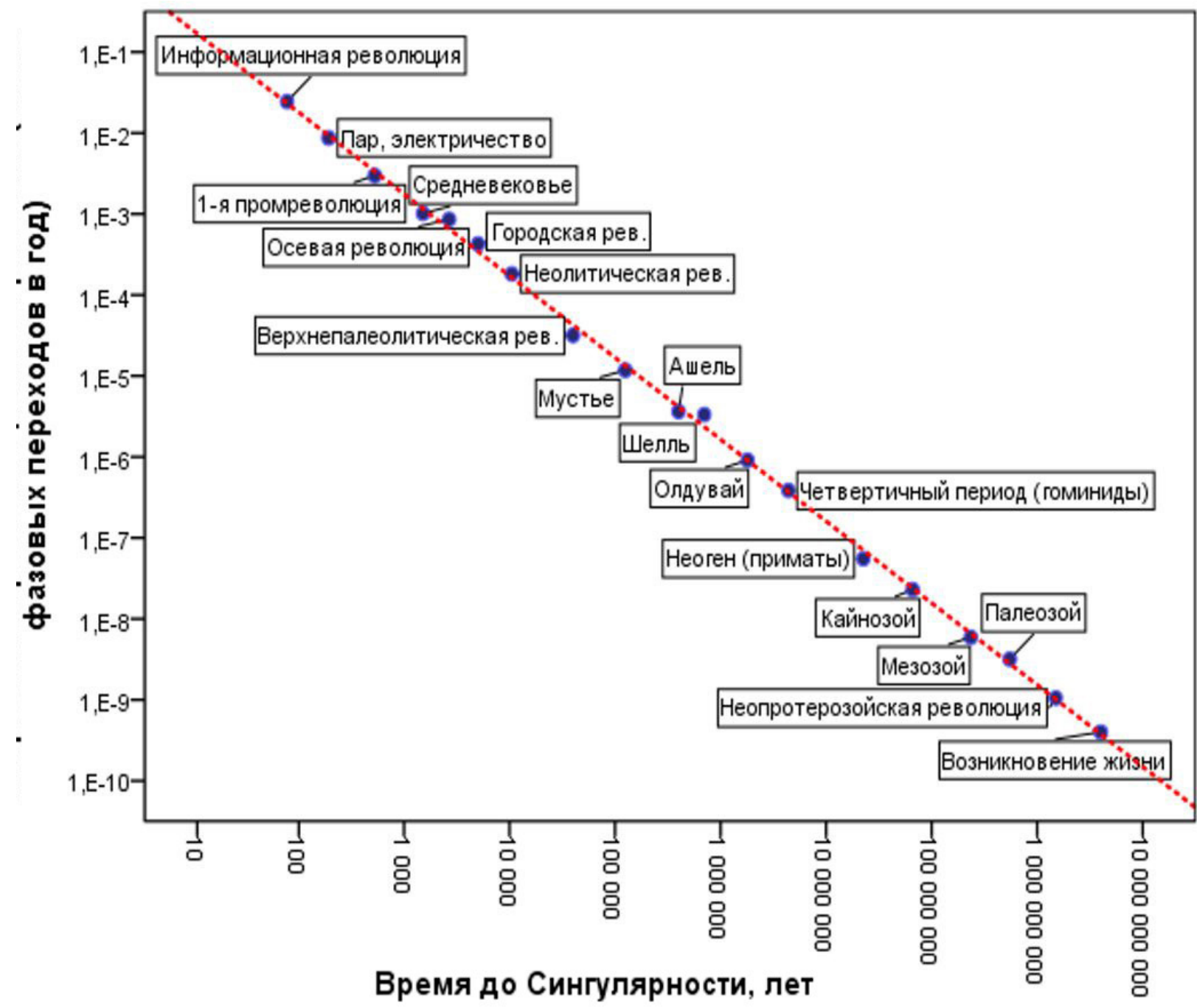

Рис. 18. Диаграмма рассеивания точек фазовых переходов Панова с наложенной линией степенной регрессии (в двойной логарифмической шкале) - для определенной методом наименьших квадратов даты Сингулярности $=2027$ г. н.э. 
взрывом и возникновением Homo sapiens sapiens) корреляция между двумя рядами выглядит реально слабой; вполне очевидно, что речь идет о совершенно независимо составленных (и достаточно отличных друг от друга) списках.

\section{Временной ряд А. Д. Панова: формальный анализ}

Теперь, после того как мы уже знаем все это, проанализируемрядПановатемжесамымспособом, как мы проанализировали выше ряд Модиса Курцвейла. Результаты этого анализа выглядят следующим образом (см. Рис 17).

В двойной логарифмической шкале соответствие между степенной моделью $y=1,886 / x^{1,01}$ (где $x$ обозначается число лет до точки Сингулярности, определенной методом наименьших квадратов как 2027 г. н.э.) и эмпирическими оценками Панова выглядит следующим образом (см. Рис. 18).

Собственно говоря, я, конечно, ожидал, что уравнение, лучше всего описывающее ряд Панова, будет выглядеть достаточно похожим на уравнение, которое мы выше получили для ряда Модиса - Курцвейла; но, честно скажу, я не ожидал, что оно окажется ДО ТАКОЙ СТЕПЕНИ ПОХОЖИМ (в особенности, если иметь в виду то обстоятельство, что Модис и Панов при идентификации своих рядов опирались на абсолютно разные источники, и полученные ими в итоге списки фазовых переходов оказались очень заметно отличающимися друг от друга).

Однако полученные нами в результате нашего анализа данных рядов уравнения оказались ПРЕДЕЛЬНО сходными (это особенно впечатляет, принимая во внимание то обстоятельство, что ни Модис, ни Панов не предпринимали попыток аппроксимировать свои ряды при помощи уравнения (10), а потому их никак нельзя подозревать в попытках «подогнать» свои ряды под это уравнение). Действительно, в неупрощенном виде степенное уравнение, лучше всего описывающие прослеживаемый в ряде Модиса - Курцвейла паттерн ускорения планетарного макроэволюционного развития, выглядит следующим образом (см. также выше Рис. 10).

$$
y=\frac{2,054}{(2029-t)^{1,003}},
$$

где, напомним, уэто скорость макроэволюционного развития (измеряемая как число фазовых переходов за единицу времени), а 2029 (г. н.э.) - точка Сингулярности, определенная методом наименьших квадратов.

В то же самое время степенное уравнение, лучше всего описывающее паттерн ускорения планетарного макроэволюционного развития, прослеживаемый в ряде Панова (2005), выглядит следующим образом (см. также выше Рис. 18):

\begin{tabular}{|c|c|}
\hline $\begin{array}{l}\text { Степенное уравнение типа (10), наиболее точно } \\
\text { математически описывающее ряд Модиса - Курцвейла }\end{array}$ & $\begin{array}{l}\text { Степенное уравнение типа (10), наиболее } \\
\text { точно математически описывающее ряд } \\
\text { Панова }\end{array}$ \\
\hline$y=\frac{2,054}{(2029-t)^{1,003}}, \quad(8), R^{2}=0,9989$ & $y=\frac{1,886}{(2027-t)^{1,01}}$ \\
\hline
\end{tabular}




$$
y=\frac{1,886}{(2027-t)^{1,01}} .
$$

В общем виде соответствующее уравнение выглядит следующим образом:

$$
y=\frac{C}{\left(t^{*}-t\right)^{\beta}} .
$$

Это уравнение имеет три параметра $-C, t^{*}$, и $\beta$. И, как мы видели, все три параметра оказались удивительно близкими, как для ряда Курцвейла Модиса, так и для ряда Панова.

\section{Формулы ускорения глобального макроэволюционного развития в рядах Модиса - Курцвейла и Панова: сравнительный анализ}

Действительно, сравнение уравнений типа (10), наиболее точно математически описывающих два соответствующих ряда, дает следующие результаты (см. Табл. 3).

Собственно говоря, на меня наиболее сильное впечатление произвело даже не то обстоятельство, что значение параметра сингулярности $\left(t^{*}\right)$ для обеих регрессий оказалось столь близким (разница всего в два года!). На меня даже большее впечатление произвело то, что значение показателя степени $\beta$ в обеих случаях оказалось столь близким к «1», что, между прочим, позволяет еще больше упростить и так уже очень простое степенное уравнение (10)

$$
y_{t}=\frac{C}{(t *-t)^{\beta}}
$$

до еще более простого гиперболического уравнения (5):

$$
y_{t}=\frac{C}{t^{*}-t}
$$

Даже третий параметр уравнения (10), $C$, оказывается очень близким в уравнениях для ряда Модиса - Курцвейла $(C=2,1)$ и ряда Панова $(C=$ $1,9)$.
Особого упоминания заслуживает исключительно высокая корреляция между теоретическим кривыми, генерируемыми чревычайно простыми уравнениями типа (5), и эмпирическими оценками, как Модиса - Курцвейла, так и Панова. Применительно к ряду Модиса - Курцвейла уравнение (5) описывает 99,89\% всей вариации скорости глобального макроэволюционного развития на протяжении нескольких миллиардов лет, в то время как для ряда Панова это соответствие составляет 99,91\% - с другой стороны, предельная близость значений $R^{2}$ для обеих регрессий (разница между ними составляет всего лишь $0.02 \%$ !) впечатляет и сама по себе (подчеркну еще раз, что данное обстоятельство выглядит особенно впечатляюще в виду того, что ни Модис, ни Панов не пытались аппроксимровать свои ряды при помощи уравнений типа (5) или (10)). ${ }^{20}$

И конечно же, не вызывает никакого удивления то, что дифференциальное уравнение описывающее ускорение темпов роста глобальной сложности в ряде Панова оказывается крайне сходным c формулой ускорения темпов глобального макроэволюционного развития для ряда Модиса Курцвейла.

Действительно, как мы уже упоминали, имеются достаточные основания упростить уравнение (9)

$$
y=\frac{1,886}{(2027-t)^{1,01}} .
$$

до простого гиперболического варианта (11)

$$
y=\frac{1,9}{2027-t} \text {. }
$$

Как мы помним, такое алгебраическое уравнение может рассматриваться как решение следующего

20 Отмечу, что в статье С.В. Циреля (2018) обосновываются утверждения, что формулы, описывающие ряды Модиса - Курцвейла и Панова, по построению имеют показатель степени $\beta=1$ и в силу практически полного совпадения начальной и двух конечных точек не могли существенно разойтись друг с другом, а небольшие различия значений числителя объясняются разным количеством фазовых переходов. 
дифференциального уравнения, которое оказывается крайне сходным с тем, что мы выше получили для ряда Модиса - Курцвейла:

$$
\frac{d y}{d t}=\frac{y^{2}}{1,9} \approx 0,5 y^{2} \text {. }
$$

Таким образом, общая формула ускорения темпов глобального макроэволюционного развития, столь точно описывающая пановскую серию «биосферных революций» оказывается практически идентичной той, что была нами обнаружена выше для ряда Модиса - Курцвейла: «увеличениетемпов макроэволюционногоразвития в a раз сопровождается увеличением скорости роста (т.е. ускорения) темпов макроэволюционного развития в $a^{2}$ раз; так, двукратное увеличение темпов макроэволюционного развития в тенденции сопровождается четырехкратным увеличением скорости роста (т.е. ускорения) темпов макроэволюционного развития; десятикратное увеличение темпов макроэволюционного развития в тенденции сопровождается стократным ускорением роста темпов макроэволюционного развития; и т.д. ...».

Намой взгляд, все этоговорито наличии достаточно строгих глобальных макроэволюционных закономерностей (описывающих рост сложности на нашей планете но протяжении нескольких миллиардов лет), которые могут удивительно точно описываться крайне простыми математическими функциями.

\section{Удивительное открытие Хайнца фон Ферстера}

Здесь представляется уместным вспомнить о том, что в 1960 г. Х. фон Ферстер, П. Мора и Л. Амиот опубликовали в журнале Science сообщение об удивительном открытии (von Foerster, Mora, and Amiot 1960). Они показали, что между 1 и 1958 г. н.э. динамика численности народонаселения мира $(N)$ может быть с необычайно высокой точно стью описана при помощи следующего поразительно простого уравнения:

$$
N_{t}=\frac{C}{\left(t^{*}-t\right)^{0.99}},
$$

где $N_{t}$ это население мира в момент времени $t$, а $C$ и $t^{*}$ это константы, при этом $t^{*}$ соответствует так называемой ,демографической сингулярности , , Параметер $t^{*}$ был оценен X. фон Ферстером и его коллегами как 2026,87, что соответствует 13 ноября 2026 г.; это, кстати, предоставило им возможность дать своей статье предельно броское название «Конец света: Пятница, 13 ноября 2026 г. от Рождества Христова» (von Foerster, Mora, Amiot 1960); однако позже было показано, что эта тенденция прослеживалась какое-то время и после 1958 г. (см., например: Капица 1999; Коротаев и др. 2010), а с другой стороны, что эта же тенденция прослеживается и в течение многих тысячелетий до н.э. (Капица 1996, 1999; Подлазов 2000, 2001, 2002; Коротаев 2006, 2010a; Коротаев, Малков, Халтурина 2005a, 2007; Kapitza 1996, 2003; Kremer 1993; Tsirel 2004; Korotayev, Malkov, Khaltourina 2006a, 2006b). Более того, М. Кремер (Kremer 1993) утверждает, что эта тенденция прослеживается с 1000000 лет назад, а С. П. Капица (1996, 1999) даже настаивал на том, что ее можно проследить, начиная примерно с 4000000 г. до н.э.

Трудно не заметить, что паттерн ускорения темпов роста численности населения мира, обнаруженный еще в 1960 г. Х. фон Ферстером в эмпирических данных по динамике численности населения Земли между 1 и 1958 гг. н.э., оказывается практически идентичным тому паттерну ускорения темпов глобального макроэволюционного развития, который мы выше обнаружили во временных рядах как Модиса - Курцвейла, так и Панова (и как будет показано в приложении к этой статье, данное обстоятельство, по всей видимости, совсем не случайно). Особо отметим, что степенная регрессия для всех трех рядов дала значение показателя степени $\beta$, крайне близкое к «1» $(1,003$ 
для ряда Модиса - Курцвейла, 1,01 для ряда Панова, и 0,99 у Х. фон Ферстера для динамики численности населения мира).

Однако и обнаруженная крайняя близость значений параметра $t^{*}$ (а это именно значение точки Сингулярности) также не может не впечатлить (степенная регрессия дает в качестве точки сингулярности 2029 г. для ряда Модиса - Курцвейла, 2027 г. - для ряда Панова, и в точности тот же 2027 г. для ряда фон Ферстера ${ }^{21}$ ).

Мы уже говорили выше, что, как и в случае с уравнениями (8) и (9), в уравнении фон Ферстера (13) значение степени в знаменателе $(0,99)$ оказывается столь слабо отличным от «1», что, как уже предлагалось С. фон Хернером (von Hoerner 1975) и С. П. Капицей $(1992,1999)$, его целесообразно использовать в следующем упрощенном виде:

$$
N_{t}=\frac{C}{t^{*}-t}
$$

Как мы видим, полученное в результате этого уравнение оказывается полностью идентичным вышеприведенному уравнению (5), которое оказалось способным описать с чрезвычайно высокой точностью общий паттерн ускорения темпов глобального макроэволюционного развития в течение как

21 Отметим, что степенная регрессия, давшая данное значение параметра сингулярности для ряда значений численности населения мира, была рассчитана более чем за 50 лет до того, как была рассчитана регрессия, давшая то же самое значение параметра $t^{*}$ для ряда Панова (собственно говоря, первая регрессия была рассчитана еще тогда, когда автор этой статьи еще даже родился). Тем не менее, я не склонен слишком серьезно относится к столь поразительному совпадению значений параметра $t^{*}$, полученных разными степенными регрессиями для разных временных рядов в совершенно разные годы; я склонен предполагать, что речь здесь все-таки в очень значительной степени идет о совпадении. В любом случае, как мы увидим ниже, нет никаких оснований ожидать что-то похожее на «конец света» в пятницу 13 ноября 2026 года от Рождества Христова...

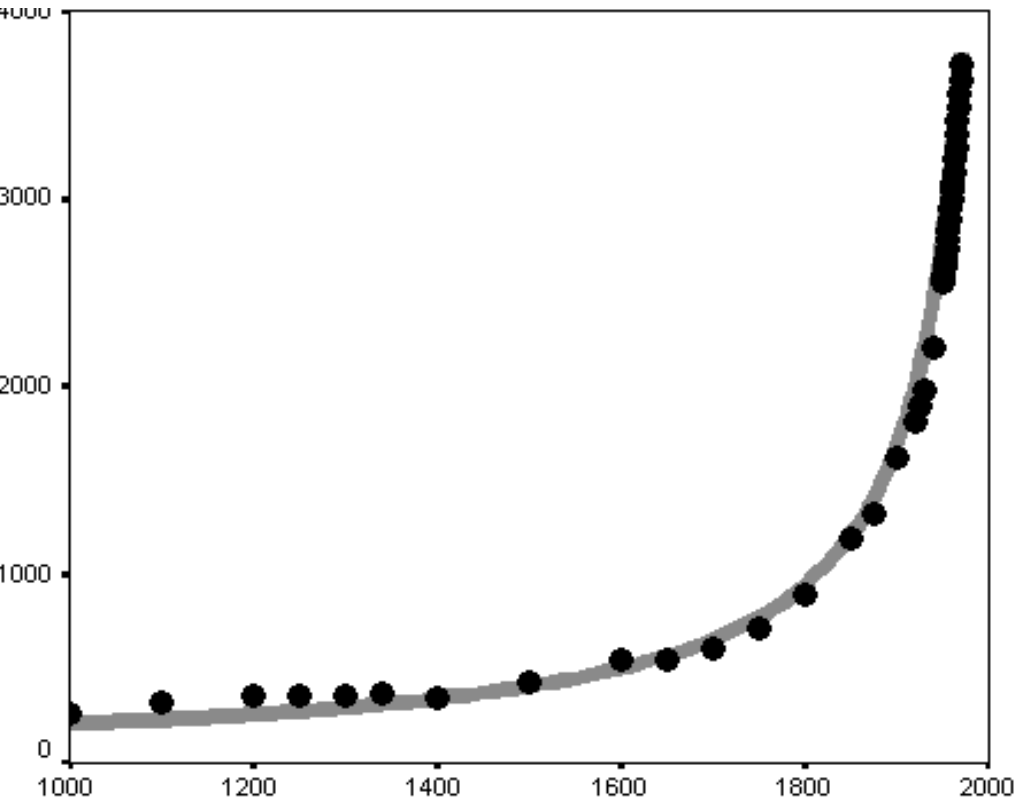

Рис. 19. Корреляция между эмпирическими оценками долгосрочной динамики численности населения мира (в миллионах чел., 1000-1970 гг.) и кривой, генерируемой уравнением фон Ферстера (15)

ПРИМЕЧАНИЕ: черные маркеры соответствуют эмпирическим оценкам численности населения мира, сделанным Мак-Эведи и Джоунсом (McEvedy, Jones 1978) для 1000-1950 гг., и эмпирическим оценкам Отдела народонаселения OOH (UN Population Division 2018) для периода с 1950 г. по 1970 г. Серая кривая сгенерирована уравнением фон Ферстера (15). Формальные характеристики этой корреляции таковы: $r=0,998 ; R^{2}=0,996 ; p=9,4 \times 10^{-17} \approx 1 \times 10^{-16}$.

минимум последних 4 млрд лет. Отметим, что уравнение (14) оказалось способным описать тренд динамики численности населения мира (вплоть до начала 1970-х гг.) с такой же предельно высокой точностью, с какой уравнение (5) оказалось способным описать ускорение темпов роста глобальной сложности (как минимум за за последние 4млрдлет). Применительно куравнению (5) это уже было продемонстрированного выше. 
Так что ниже имеет смысл продемонстрировать это для уравнения фон Ферстера (14).

Возьмем уравнение (14). Теперь заменим там $t^{*}$ на 2027 (это просто результат округляния полученного фон Ферстером значения точки сингулярности, 2026,87), а $C$ - на 215000.22 Это даст нам вариант уравнения фон Ферстера - фон Хенера - Капицы с определенными параметрами

$$
N_{t}=\frac{215000}{2027-t}
$$

Общее совпадение кривой, описываемой уравнением фон Ферстера, и наиболее детального ряда эмпирических оценок выглядит следующим образом (см. Рис. 19).

Как мы видим, и на самом деле уравнение (14) оказывается способным описать динамику ускорения роста численности населения мира (вплоть до начала 1970-х годов) таким же удивительно точным образом, каким уравнение (5) способно описать общий паттерн глобального макроэволюционного ускорения за последние 4 миллиарда лет.

В контексте Большой истории очень важным представляется то обстоятельство, что уравнение (5), описывающее ускорение темпов глобального макроэволюционного ускорения и уравнение (14), описывающее рост численности населения Земли, оказываются полностью идентичными. Более того, эмпирический и математический анализ показывает, что между ними существует очень глубокая взаимосвязь, и что они описывают две стороны одного процесса (см. Приложение к данной статье).

\section{О формуле ускорения глобального эволюционного развития}

Честно скаже, что у меня были серьезные сомнения,

22 Отметим, что все вычисления приводятся ниже в миллионах человек. Отметим также, что использованное нами значение параметра $C$ несколько отличается от значения, использовавшегося X. фон Ферстером. когда я впервые встретился с расчетами Панова и Модиса (и я не удивлен, что у большинства историков возникают очень похожие сомнения, когда они видят эти работы). У меня возникло много возражений относительно точности многих описаний их «канонических вех», относительно адекватности их отбора и и точности датировок. Честно скажу, что я начал серьезно относиться к расчетам Модиса и Панова, только когда я сам проанализировал два соответствующих временных ряда, идентифицированных (как мы видели выше) полностью независимо друг от друга двумя разными исследователями, использующими совершенно разные источники. При этом я анализировал их при помощи математической модели, которая не применялась к их анализу ни Модисом, ни Пановым, и обнаружил, что они описываются необычно точным образом почти идентичной математической гиперболической функцией. На мой взгляд, это заставляет предполагать объективное наличие довольно простой гиперболической закономерности ускорения глобального макроэволюционного развития, наблюдаемого на Земле в течение последних 4 миллиардов лет. Это впечатление стало еще более сильным, когда уравнение, описывающее картину ускорения планетарной макроэволюции в рядах Модиса - Курцвейла и Панова, оказалось полностью идентичным уравнению, найденному еще в 1960 году Хайнцем фон Ферстером, показавшему уже тогда, что оно способно с необычайной точностью описать глобальный паттерн ускорения роста численности населения Земли между 1 и 1958 гг.

У меня были основания ожидать, что планетарное макроэволюционное ускорение за последние 4 миллиарда лет может быть описано единым гиперболическим уравнением с достаточно высокой точностью, так как предыдущие исследования показали, что и биологическая и социальная эволюция могут описываться с достаточно высокой точностью простыми 
гиперболическими уравнениями ${ }^{23}$, но, должен сказать, что и я был удивлен, когда я обнаружил, что макроэволюционное ускорение за последние 4 миллиарда лет описывается единым гиперболическим уравнением с такой высокой точностью.

На мой взгляд, все это заставляет предполагать существование достаточно строгих глобальных макроэволюционных закономерностей (описывающих рост глобальной сложности на протяжении нескольких миллиардов лет), которые могут быть неожиданно точно описаны при помощи предельно простых математических функций, и в том числе наличие следующей дифференциальной формулы ускорения темпов роста (у) глобальной сложности:

$$
\frac{d y}{d t}=\frac{y^{2}}{C},
$$

где $\mathrm{C}$ представляет собой параметр следующего гиперболического уравнения:

$$
y_{t}=\frac{C}{t^{*}-t},
$$

где $t^{*}$ - это дата Сингулярности.

Также отнюдь не безынтересным представляется то обстоятельство, что даты сингулярности для всех трех (очень различных) рассмотренных нами временных рядов оказались практически идентичными (2029 г. для ряда Модиса-Курцвейла и 2027 г. для рядов Панова и фон Ферстера).

23 Марков, Коротаев 2007, 2008а, 2008б, 2008в, 2009а, 2009б; Марков, Анисимов, Коротаев 2010, 2011; Коротаев 2007, 2010б; Коротаев, Марков 2006; Коротаев, Комарова, Халтурина 2007; Коротаев, Малков, Халтурина 2005б; Коротаев, Халтурина 2009; Korotayev 2005, 2006a, 2006b, 2007a, 2007b, 2008, 2009, 2012, 2013; Korotayev, Khaltourina 2006; Khaktourina et al. 2006; Korotayev, Malkov, Khaltourina 2006a, 2006b; Markov, Korotayev 2007, 2008, 2009; Markov, Anisimov, Korotayev 2010; Korotayev, S. Malkov 2012; Korotayev, Markov 2014, 2015; Grinin, Markov, Korotayev 2013, 2014; 2015; Korotayev, A. Malkov 2016; Korotayev, Zinkina 2017.

\section{К интерпретации Сингулярности. Место Сингулярности в Большой истории и глобальной эволюции}

Но насколько серьезно мы должны относиться к «предсказанию» сингулярности, содержащемуся в таких математических моделях? Следует ли нам вместе с Курцвейлом действительно ожидать, что где-то в районе 2029 года мы будем иметь дело с ускорением глобального технологического роста на несколько порядков (что, действительно, вытекает из уравнения (4), если понимать его буквально $\left.{ }^{24}\right)$ ?

Например, можем ли мы использовать то обстоятельство, что наш анализ ряда Модиса Курцвейла выявил Сингулярность в районе 2029 г. как указание на то, что в районе этого времени нам следует ожидать начало «Девятой пороговой вехи Большой истории» (Big History Threshold 9)? Отметим, что некоторые специалисты в области Большой истории склонны относиться к таким «математически обоснованным» предсказаниям совершенно серьезно. Наиболее известен из них А.П.Назаретян.В своейстатьес симптоматическим заголовком «Мегаистория и ее “загадочная сингулярность”» в ведущем журнале Российской академии наук он утверждает следующее:

"Солнечная система образовалась около 4,6 млрд лет назад, а самые первые признаки жизни на Земле насчитывают до 4 млрд лет. Таким образом, наша планета стала одной из (вероятно, множества) точек, на которых локализовалась последующая эволюция Метагалактики. Хотя ее ускорение замечено давно, в последнее время обнаружилось новое обстоятельство. Австралийский экономист и историк-глобалист Г. Снукс, российский физик А.Д. Панов и американский математик P. Курцвейл

24 Это делает, например, А. П. Назаретян (2015a, 2015б; Nazaretyan 2015, 2016, 2017, 2018). 
независимо, по разным источникам и с использованием разного математического аппарата сопоставили временные интервалы между глобальными фазовыми переходами в биологической, прасоциальной и социальной эволюции (Панов 2005, 2008; Kurzweil 2005; Snooks 1996; Вайнберг 1977). Расчеты показывают, что периоды сокращались по строго убывающей геометрической прогрессии, то есть ускорение эволюции на Земле следовало логарифмическому закону” (Назаретян 2015: 759).

Далее А. П. Назаретян утверждает:

“экстраполировав линию гиперболического ускорения в будущее, исследователи пришли к единодушному и еще более шокирующему выводу: около середины XXI в. она упирается в точку финальной (большой) сингулярности. Кривая заворачивает в вертикаль, то есть скорость эволюционного процесса стремится к бесконечности, а интервалы между фазовыми переходами - к нулю" (Назаретян 2015: 761; см. также Nazaretyan 2017: 32).

Как мы видим, А. П. Назаретян использует математические расчеты ${ }^{25}$ даты Сингулярности глобальной эволюционной гиперболы для предсказания возможной даты того, что в

25 По всей видимости, речь идет о математических расчетах А. Д. Панова, так как Г. Снукс и Р. Курцвейл, упоминаемые Назаретяном в первой цитате наряду с Пановым, таких расчетов не проводили. Отметим, впрочем, что А. Д. Панов пользовался для своих расчетов не гиперболической, а логарифмической моделью, а «экстраполяции линии гиперболического ускорения в будущее» по ряду Панова до меня, насколько мне известно, никем не проводилось (вышеупомянутый перенос Курцвейлом даты Сингулярности на 2029 год, впрочем, может свидетельствовать о том, что ктото из сотрудников Курцвейла все-таки провел анализ ряда Модиса - Курцвейла с использованием гиперболической модели, но о публикации результатов этого анализа мне неизвестно). терминологии основоположника Большой истории Д. Кристиана (Christian 2008) можно было бы назвать «Девятой пороговой вехой Большой истории» (Big History Threshold 9) ${ }^{26}$ (которая, согласно Назаретяну будет существенно более значимой, чемпредшествующие Вехи 7 (“Аграрная революция") and 8 (“Модернизационная революция "). ${ }^{27}$

Однако дают ли расчеты, проделанные А. Д. Пановым в 2003-2005 гг. или нами выше в этой статье, действительные основания ожидать Сингулярности/наступления 9-й пороговой вехи Большой истории между 2029 и 2050 гг.? Как, наверное, уже понятно, я склонен дать на этот вопрос однозначно отрицательный ответ.

Собственно говоря, как мы могли видеть, данная статья представляет собой по всей видимости первую попытку в явном виде «экстраполировать линию гиперболического ускорения в будущее» ${ }^{28}$. Хотя А. П. Назаретян и утверждает обратное, подобная попытка не предпринималась Д. Снуксом (Snooks 1996), который непытался вычислять какие бы то ни было математические сингулярности. Никаких формальных попыток «экстраполировать линию гиперболического ускорения в будущее» с использованием каких-либо математических

26 Напомним, что в качестве 5-й пороговой вехи Большой истории Д. Кристиан рассматривает возникновение жизни, 6-й - антропогенез и возникновение «коллективного обучения» (collective learning), 7-й - неолитическую революцию, а 8-й - глобальную модернизацию последних веков, особенно активно протеквшую в XIX-XX вв. (Modern Revolution).

27 По крайней мере, А. П. Назаретян пишет о «завершающем фазовом переходе, сопоставим по значению с появлением жизни» (Назаретян 2015: 761).

28 Демонстрируя вместе с тем, что обнаруживаемая сингулярность должна скорее служить индикатором перегиба, после которого темпы глобального макроэволюционного развития начнут систематически в долгосрочной перспективе замедляться. 
методов не предпринималось Р. Курцвейлом уже хотя бы потому, что он до сих пор уверен в том, что он имеет дело с экспоненциальным, а не гиперболическим ускорением. Таким образом, едва ли ни еденственным (до нас) исследователем, предпринявшим попытку математически рассчитать время сингулярности для линии ускорения планетарной эволюции, является А. Д. Панов (2004, 2005, 2006, 2008; Panov 2005, $2011,2017)$ - хотя с некоторыми оговорками это можно также сказать про отношениях это можно сказать про С. Н. Гринченко (2001, 2004, 2006, 2007 и др.), Т. Модиса (Modis 2002, 2003) и Д. ЛеПуара (LePoire 2013, 2015).

Использованная Пановым методика расчета Сингулярности существенно отличалась от «экстраполирования линии гиперболического ускорения в будущее» (это скорее та самая методика, которая была использована нами, а не Пановым); однако нет сомнений в том, что А. Д. Пановым была применена не менее строгая методика расчета времени Сингулярности планетарной эволюции. Но каковы были результаты этих расчетов? После того, как Панов применил свою методику математического анализа к своему временному ряду, начинающемуся с фазового перехода 0 («Возникновение жизни на Земле») и заканчивающемуся на фазовом переходе 19 («Кризис и распад социалистического лагеря, информационная глобализация»), он обнаружил, что точка сингулярности для его временного ряда находится вовсе не «около середины XXI века», как это утверждает Назаретян (2015: 761), а приходится на 2004 г. н.э. (!) ${ }^{29}$ (Панов 2005: 130; Panov 2005: 222). При этом А. П. Назаретян даже, кажется, не

29 Между прочим, это очень близко к сингулярности 2005 года, которую мы ранее обнаружили при анализе ряда данных А. Мэддисона (Maddison 2001) по мировому ВВП за 1-1973 гг. (Коротаев, Малков, Халтурина 2005a, 2005б, 2007, 2008; Korotayev, Malkov, Khaltourina 2006a, 2006b) и которую еще раньше в данных по мировому ВВП обнаружил Р. Таагепера (Taagepera 1976). заметил, что вскоре после обнаружения Пановым точки Сингулярности Панов занялся изучением постсингулярногоразвитиячеловечества(ивообще вопросом о постсингулярных цивилизациях) и тесно связанным с этим вопросом о глобальном замедлении темпов научно-технического прогресса (Панов 2009, 2013; Panov 2011, 2017). Как пишет Д. ЛеПуар, “прослеживаемые в Большой истории тенденции к ускоряющимся изменениям и росту сложности и связанная с ними тенденция к ускоренному росту потребления энергии не могут продолжаться до бесконечности. Мы исследовали признаки потенциального замедления темпов изменений в экономике, технологии и социальной сфере. Это не означает, что изменения прекратятся, просто темпы изменений уже не будут ускоряться. Фактически, к точке перегиба в логистической кривой обучения была сделана только половина открытий. Поскольку в истории жизни, человека и технологической цивилизации было три основных этапа ${ }^{30}$, продолжение логистической кривой предполагает еще три фазы ${ }^{31}$. Направление развития технологий указывает на следующий этап, включая усовершенствованные технологии изменения природы человека посредством усовершенствованных биотехнологий и компьютерной интеграции ... Слишком быстрое изменение не всегда хорошо. Оно приводит к тому, что эффективность систем падает, потому что мы имеем мало долгосрочных ожиданий» (LePoire 2013: 115-116). В качестве важных факторов начавшегося замедления темпов глобального макроэволюционного развития ЛеПуар называет «рост себестоимости производимой энергии, ограниченные природные ресурсы, снижение

30 Речь идет о трех этапах, связанных с возникновением и эволюцией жизни, возникновением и эволюцией человека, a также возникновением и эволюцией технологической цивилизации (при этом границы между этими этапами приблизительно соответствуют Пороговым вехам Большой истории № 5, 6 и 8).

31 И, таким образом, еще три Пороговые вехи Большой истории. 
темпов фундаментальных открытий в области физических наук и необходимость инвестиций в охрану окружающей среды» ${ }^{32}$ (LePoire 2013: 109).

Отметим также, что Т. Модис (Modis 2002, 2003, $2005,2012)$ тоже интерпретирует максимальное ускорение темпов роста глобальной сложности, выявляемое им в районе 2000 г. н.э., именно как точку перегиба, после которой он прогнозирует нарастающее снижение темпов роста глобальной сложности. Собственно говоря, наиболее ранняя известная мне попытка математически выявить математическую сингулярность в ряду событий планетарной эволюции ${ }^{33}$, которые Модис бы назвал «каноническими вехами», была предпринята в 2001 г. (т.е. всего за год до пуликации основополагающей статьи Т. Модиса в Technological Forecasting and Social Change) С. Н. Гринченко (см. Гринченко 2001; см. также: Гринченко 2006, 2007, 2015; Гринченко, Щапова 2017; Щапова, Гринченко 2017; Grinchenko 2006, 2011; Grinchenko, Shchapova 2010, 2016, 2017); точка сингулярности была им математически определена ${ }^{34}$ как 1981 г. н.э., в то время как последующий период был интерпретирован С. Н. Гринченко точно так же, как и Модисом как период период прогрессирующего замедления «скорости макроэволюции». Отметим, что это

32 О связи между ростом инвестиций в охрану окружающей среды и снижением темпов экономического роста см. также, например: Коротаев, Божевольнов 2010.

33 Отметим, что наиболее ранняя изветная нам попытка математически выявить сингулярность на основе данных по человеской истории была предпринята еще в 1909 г. Г. Адамсом, который обнаружил ее в районе 1921 года при одном способе подсчетов, а при втором способе подсчетов в районе 2025 года (Adams 1969 [1909]: 308) - что, конечно, совсем не далеко от демографической сингулярности 2027 года, обнаруженной Х. фон Ферстером в 1960 г., а также от планетарной сингулярности 2027 года, обнаруженной нами выше во временном ряде Панова...

34 Надо заметить, что для вычисления сингулярности по своим данным С. Н. Гринченко использовал методику, существенно отличную от использованной как А. Д. Пановым, так и нами. хорошо коррелирует с идентификацией нами 1973 года как точки перегиба, после квадратичногиперболический тренд ускорения роста мирового ВВП начал меняться на прямо противоположный тренд к замедлению роста этого показателя (Коротаев 2006; Коротаев, Малков, Халтурина 2007; Коротаев и др. 2010; Коротаев, Божевольнов 2010; Акаев и др. 2014; Садовничий и др. 2014; Коротаев, Билюга 2016; Korotayev 2006). Bce это хорошо подтверждается растущим объемом данных, свидетельствующих о начале долгосрочной тенденции к замедлению темпов научно-технического и экономического роста (см., например: Крылов 1999, 2002, 2007; Панов 2009, 2013; Акаев 2010; Коротаев, Малков, Халтурина 2007; Коротаев, Божевольнов, 2010; Коротаев и др. 2010; Коротаев, Билюга 2016; Huebner 2005; Khaltourina, Korotayev 2007; Maddison 2007; Modis 2002, 2005, 2012; Gordon 2012; Teulings and Baldwin 2014; Piketty 2014; LePoire 2005, 2009, 2013, 2015, 2016; Korotayev, Bilyuga 2016; Summers 2016; Cervellati, Sunde, Zimmermann 2017; Taylor, Tyers 2017; Jones 2018; Popović 2018 etc.).

Итак, насколько серьезно мы должны относиться к «предсказанию» сингулярности, содержащемуся в гиперболических математических моделях глобального развития? Или-следует ли нам вместе с Курцвейлом ожидать, что где-то в районе 2029 года мы будем реально иметь дело с ускорением глобального технологического роста на несколько порядков (что, действительно, вытекает из уравнения (4), если понимать его буквально $\left.{ }^{35}\right)$ ?

Как уже понятно, я склонен дать на этот вопрос однозначно отрицательный ответ. И в заключение приведу еще один аргумент в пользу данного отрицательного ответа. На мой взгляд, отрицательный ответ на этот вопрос вытекает, например, из известных нам эмпирических данных

35 И именно это, как мы помним, делает, например, А. П. Назаретян (2015a, 2015б; Nazaretyan 2015, 2016, 2017, 2018). 
по динамике численности населения мира и установленных к настоящему времени механизмов этой динамики. Как мы помним, формула гиперболического роста численности населения Земли, открытая Хайнцем фон Ферстером, идентична формуле ускорения темпов глобального макроэволюционного развития, прослеживаемого в рядах Модиса - Курцвейла и Панова, и она характеризуется параметром сингулярности (2027 г. н.э.), который просто идентичен для формулы ускорения в ряду Панова и имеет разницу всего лишь в 2 года для ряда Модиса - Курцвейла. Однако каковы основания ожидать, что к пятнице 13 ноября 2026 года темпы прироста населения мира увеличиваться на несколько порядков, как это подразумевает уравнение фон Ферстера? Ответ на этот вопрос очень ясен. Нет абсолютно никаких оснований этого ожидать. Действительно, как мы показали довольно давно, «когда фон Ферстер и его коллеги давали своей статье (von Foerster, Mora, Amiot, 1960) знаменитое название "Судный день: пятница, 13 ноября 2026 г.”, они вовсе не имели в виду, что население Земли в этот день действительно может стать бесконечным (хотя “эсхатологические" выводы из гиперболических моделей роста Мир-Системы без каких-либо достаточных на то оснований делаются до сих пор (например (Johansen, Sornette 2001)). Из этой статьи, скорее, вытекал прямо противоположный прогноз - наблюдавшийся вплоть до 1960 г. на протяжении многих веков гиперболический рост мирового населения должен испытать в самые ближайшие годы радикальную трансформацию и смениться на принципиально иной тип демографической макродинамики. Отметим, что этот прогноз стал блестяще оправдываться всего лишь через несколько лет после публикации статьи фон Ферстера и его коллег (Коротаев, Малков, Халтурина, 2007, с. 14-22). Мир-Система начала свой выход из режима с обострением» (Коротаев, Малков, Халтурина 2008: 99; см. также: Коротаев, Халтурина 2009; Зинькина и др. 2016; Зинькина, Коротаев 2017; Korotayev 2008: 154).
Действительно, начиная с начала 1970-х гг. кривая роста численности населения мира стала все больше отклоняться от гиперболической траектории (ср. Рис. 19 и 20) (см., например, Капица 1999; Коротаев, Малков, Халтурина 2005a, 2007; Коротаев 2015, 2016; Kapitza 2003, 2006, 2010; LiviBacci 2012; Korotayev, Malkov, Khaltourina 2006a, 2006b; Korotayev, Goldstone, Zinkina 2015; Grinin, Korotayev 2015), и за последние десятилетия она приняла определенно логистическую форму - тенденция к гиперболическому ускорению сменилась на тенденцию к логистическому замеделению (см. Рис. 20).

В некоторых отношениях вполне можно сказать, что X. фон Ферстер открыл сингулярность глобальной демографической истории; можно сказать, что он обнаружил, что человеческая МирСистема приближалась к сингулярному периоду в своей истории, когда тенденция гиперболического ускорения, которой она следовала много тысячелетий (a, по мнению некоторых, даже несколько миллионов лет), будет заменена на противоположный тренд к замедлению. Именно через этот сингулярный период мы сейчас и проходим. Процессы и механизмы данного разворота трендов к настоящему времени очень тщательно изучены ${ }^{36}$ и известны как «глобальный демографический переход» (Капица 1999, 2007; Подлазов 2001, 2017; Романчук, Медведева 2009; Коротаев 2015; Kapitza 2003, 2006, 2010; Korotayev, Goldstone, Zinkina 2015; Podlazov 2017). При этом особое внимание здесь стоит обратить на то обстоятельство, что в случае с глобальной демографической эволюцией переход от гиперболического ускорения к логистическому замедлению начался за несколько десятилетий до

36 См., например; Вишневский 1976, 2005; Коротаев, Малков, Халтурина 2005а, 2007; Римашевская и др. 2012; Коротаев 2015; Подлазов 2017; Chesnais 1992; Caldwell et al. 2006; Khaltorina et al. 2006; Korotayev, Malkov, Khaltourina 2006a, 2006b; Korotayev 2009; Gould 2009; Dyson 2010; Reher 2011; Livi-Bacci 2012; Choi 2016; Podlazov 2017. 


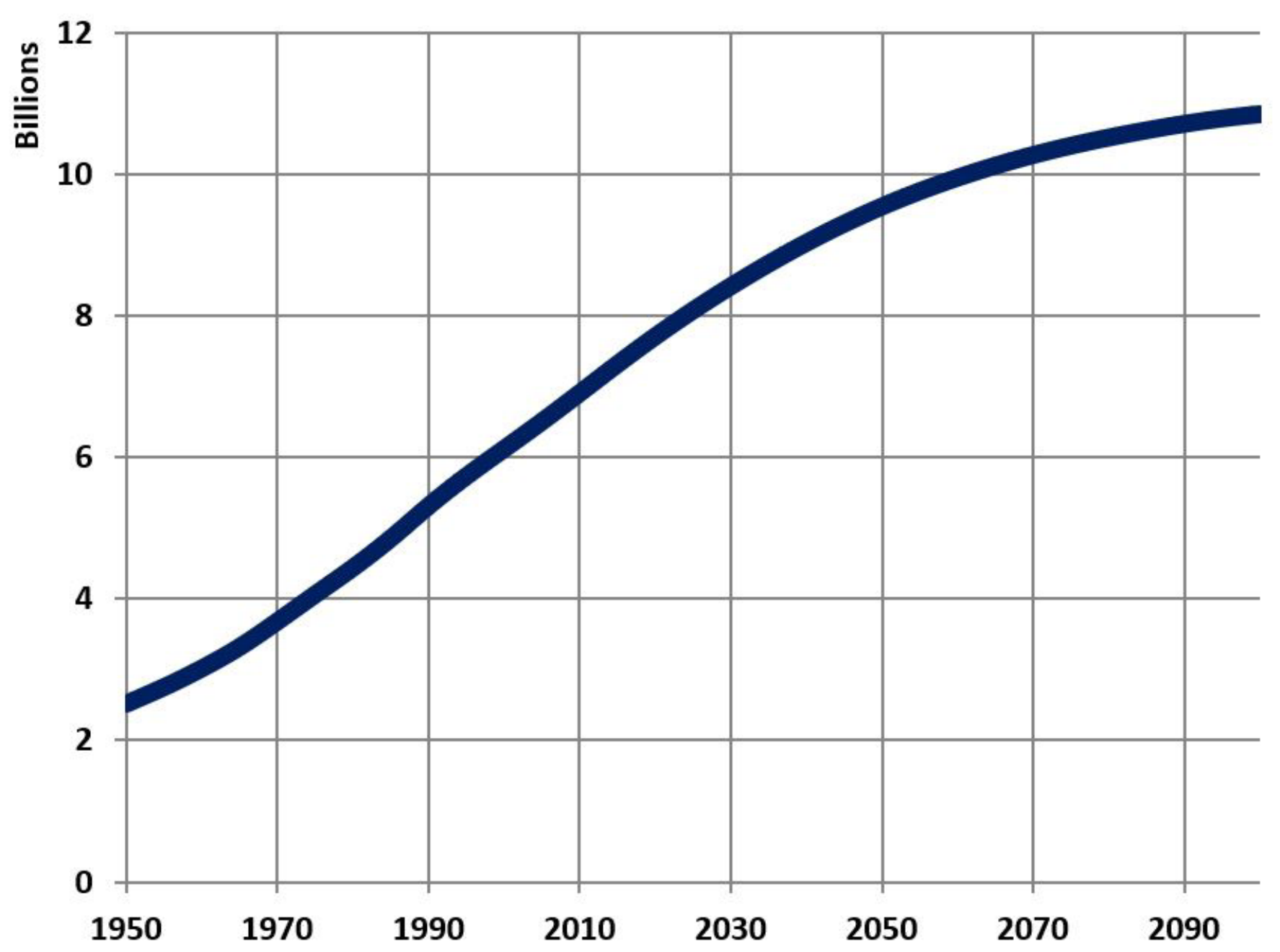

Рис. 20. Динамика численности населения мира (млрд), эмпирические оценки Отдела народонаселения ООН за 1950-2015 гг. со средним прогнозом до 2100 г.

Источник: UN Population Division 2018.

даты Сингулярности, математически вычисленной Х. фон Ферстером.

На мой взгляд, имеются основания утверждать, что замедление скорости глобального макроэволюционного развития также уже началось - и началось оно так же за несколько десятилетий до той точки сингулярности, которую можно математически выявить в глобальных эволюционных рядах Модиса - Курцвейла и Панова ${ }^{37}$.

\section{Заключение}

Итак, проведенный нами анализ позволяет предполагать наличие достаточно строгих

37 Кстати, вполне возможно, что началось оно в то же самое время, как и начало выхода Мир-Системы из демографического режима с обострением (т.е. в начале 1970-х гг.) (см., например: Коротаев, Божевольнов 2010). 
глобальных макроэволющионных закономерностей (описывающих эволющию сложности на нашей планете за последние несколько миллиардов лет), которые могут удивительно точно описываться крайне простыми математическими функциями. Вместе с тем этот анализ заставляет предполагать, что в районе точки сингулярности нет основания вслед за Курцвейлом ожидать невиданного (на много порядков) ускорения темпов технологического развития; имеются бо́льшие основания интерпретировать эту точку как индикатор зоны перегиба, после прохождения которой темпы глобальной эволюции будут систематически в долгосрочной перспективе замедляться.

\section{Приложения $^{38}$ \\ Приложение 1. О взаимосвязи между формулой увеличения планетарной сложности и уравнением гиперболического роста численности населения Земли}

Как мы могли видеть выше, формула ускорения роста планетарной сложности / глобального макроэволюционного развития (5) оказалась практически идентичной уравнению гиперболического роста численности населения Земли (14). Действительно, уравнение ускорения роста планетарной сложности в ряде Панова выглядит следующим образом (ср. выше формулу (11)):

$$
y_{t}=\frac{C_{1}}{2027-t}
$$

Нетрудно видеть, что эта формула практически идентична открытому $\mathrm{X}$. фон Ферстором еще в 1960 году закону гиперболического роста численности населения Земли (ср. выше формулу (15)):

38 Хочу выразить свою благодарность С. Г. Шульгину и А. А. Фомину за помощь с содержащимися в Приложениях 1 и 2 математическими расчетами.

$$
N_{t}=\frac{C_{2}}{2027-t} .
$$

Как мы видим, различаются эти уравнения только значениями параметра С в знаменателе.

Между тем этот паттерн ускорения не вполне тривиален. При этом важно отметить, что, несмотря на существенное сходство, паттерн ускорения темпов планетарной эволюции (прослеживаемый в рядах Панова и Модиса - Курцвейла) заметно отличается от паттерна, открытого фон Ферстером применительно к росту населения мира.

Дело в том, что $y$ уравнения (16) - это ТЕМПЫ роста глобальной сложности, поэтому $\mathrm{y}=\mathrm{C}_{1} / 2027-\mathrm{t}$ описывает не рост глобальной сложности, а рост ТЕМПОВ увеличения глобальной сложности. А значит, $y$ уравнения (16) соответствует не численности населения (N) уравнения (15), а ТЕМПАМ роста численности населения; при этом уравнения, описывающие рост численности населения Земли $(\mathrm{N})$, достаточно заметно отличаются от уравнений описывающих динамику ТЕМПОВ роста этой численности (dN/dt).

Действительно, как мы помним, алгебраические уравнения типа

$$
y_{t}=\frac{C}{t^{*}-t}
$$

являются решениями дифференциального уравнения типа

$$
\frac{d y}{d t}=\frac{y^{2}}{C}
$$

Таким образом, если численность населения Земли растет по закону $N=C_{2} / t^{*}-t$ (14), то темпы роста его числнности будут меняться по совсем другому закону:

$$
\frac{d N}{d t}=\frac{N^{2}}{C}
$$

С другой стороны, подставляя $N=C / t^{*}-t$ в $d N / d t$ $=N^{2} / C$, получаем 


\begin{tabular}{|c|c|c|}
\hline & $\begin{array}{l}\text { Уравнения, описывающие рос } \\
\text { глобальной сложности (n) (по ряд } \\
\text { Панова) }\end{array}$ & $\begin{array}{l}\text { Уравнения, описываюшие рост } \\
\text { численности населения Земли } \\
(N) \text { (по ряду фон Ферстера - } \\
\text { Капищы) }\end{array}$ \\
\hline $\begin{array}{l}\text { Уравнения роста глобальной } \\
\text { сложности } / \text { численности } \\
\text { населения }\end{array}$ & $n_{t}=A-C_{1} \cdot \ln (2027-t)$ & $N_{t}=\frac{\mathrm{C}_{2}}{2027-t}$ \\
\hline $\begin{array}{l}\text { Уравнения } \quad \text { увеличения } \\
\text { ТЕМПОВ роста глобальной } \\
\text { сложности / численности } \\
\text { населения }\end{array}$ & $y=\frac{d n}{d t}=\frac{\mathrm{C}_{1}}{2027-t}$. & $\frac{d N}{d t}=\frac{\mathrm{C}_{2}}{(2027-t)^{2}}$ \\
\hline
\end{tabular}

Табл. 4. Сопоставление законов роста глобальной / планетарной сложности и увеличения численности населения Земли

$$
\frac{d N}{d t}=\left(\frac{C}{t^{*}-t}\right)^{2}: C=\frac{C^{2}}{\left(t^{*}-t\right)^{2}}: C=\frac{C}{\left(t^{*}-t\right)^{2}} .
$$

Таким образом, если ЧИСЛЕННОСТЬ населения Земли растет по ПРОСТОМУ гиперболическому закону

$$
N_{t}=\frac{\mathrm{C}_{2}}{2027-t},
$$

то ТЕМПЫ роста его численности будут увеличиваться по КВАДРАТИЧНОМУ гиперболическому закону:

$$
\frac{d N}{d t}=\frac{\mathrm{C}_{2}}{(2027-t)^{2}} \text {. }
$$

Сравним это теперь с уравнениями, описывающими рост глобальной/планетарной сложности. Вслед за Фоминым (2018) и Пановым (2004, 2005) обозначим уровень глобальной сложности как $n .^{39}$ При таком подходе многократно упоминавшаяся выше переменная $y$ может быть записана как $\mathrm{dn} / \mathrm{dt}$. Как мы помним, темпы роста

39 При этом уровень планетарной сложности на данный момент времени будет исчисляться числом (n) происшедших до данного момента времени «биосферных революций» (по Панову - Фомину) или «скачков сложности» / complexity jumps (по Модису) (исходя из допущения, что каждый «скачок сложности») добавляет к текущему $n$ еще один порядок/ уровень сложности. планетарной сложности (y $=\mathrm{dn} / \mathrm{dt})$ увеличивались в ряду Панова ${ }^{40}$ по закону, заметно отличному от уравнения, описывающего динамику роста темпов увеличения численности населения Земли (18):

$$
y=\frac{d n}{d t}=\frac{\mathrm{C}_{1}}{2027-t}
$$

При этом решение дифференциального уравнения (11) дает следующий результат:

$$
n_{t}=A-C_{1} \cdot \ln (2027-t),
$$

где $\mathrm{A}$ - константа ${ }^{41}$.

Таким образом, планетарная сложность $(n)$ растет по существенно другому закону, чем численность

40 Впрочем, в ряду Модиса - Курцвейла они увеличивались по тому же самому закону (при несколько других значениях параметров $\mathrm{C}_{1}$ и $\left.t^{*}\right)$.

41 Между прочим, проделанные А. А. Фоминым (2018) расчеты позволяют установить значение этой константы для ряда Панова. Она оказывается равной величине $\ln T /$ $\ln \alpha$, где $T$ - это время существования жизни на Земле (которое может быть примерно оценено как 4 млрд лет), а $\alpha$ - это «коэффициент ускорения исторического времени, показывающий, во сколько раз каждая последующая эпоха короче предыдущей» (Панов 2005: 128) (подробнее о коэффициенте $\alpha$ см. ниже). Подробнее см. Приложение 2. 
населения мира (N) (см. Табл. 4):

Как мы видим, численность населения Земли (N) росла (до начала 1970-х гг.) по простому гиперболическому закону $\left(\mathrm{N}_{\mathrm{t}}=\mathrm{C} / \mathrm{t}^{*}-\mathrm{t}\right)$, a планетарная сложность увеличивалась по логарифмически-гиперболическому закону $\left(\mathrm{n}_{\mathrm{t}}=\right.$ const $\left.-\mathrm{C} \cdot \ln \left(\mathrm{t}^{*}-\mathrm{t}\right)\right)$.

Кроме того, темпы роста численности населения мира (dN/dt) менялись (до начала 1970-х гг.) по КВАДРАТИЧНО-гиперболическому закону $(\mathrm{dN} / \mathrm{dt}$ $\left.=\mathrm{C} /\left(\mathrm{t}^{*}-\mathrm{t}\right)^{2}\right)$, а темпы роста планетарной сложности менялись по ПРОСТОМУ гиперболическому закону $\left(\mathrm{dn} / \mathrm{dt}=\mathrm{C} / \mathrm{t}^{*}-\mathrm{t}\right)$.

Тем не менее, остается вопрос - случайно ли то, что ТЕМПЫ роста глобальной сложности в ряде Панова $(\mathrm{dn} / \mathrm{dt})$ и численность населения Земли $(\mathrm{N})$ вплоть до начала 1970-х годов росли по одному и тому же закону: $\mathrm{x}_{\mathrm{t}}=\mathrm{C} / 2027-\mathrm{t}$ ? Отметим, что проведенные А. А. Фоминым (2018) расчеты показывают, что это совсем не случайно.

Действительно, А. А. Фомин (2018) обращает внимание на то, что на протяжении социальной фазы Большой истории/универсальной эволюции население Земли между каждой парой биосферных революций увеличивалось примерно в одно и то же число раз (где-то порядка 2,8). Отметим, что это совсем не плохо согласуется со многими математическими моделями гиперболического роста численности населения Земли ${ }^{42}$, рассматривающим его как следствие функционирования механизма положительной обратной связи второго порядка между демографическим ростом и технологическим

42 См., например: Подлазов 2000, 2001, 2002; Коротаев, Малков, Халтурина 2005a, 2005б, 2007, 2008; Taagepera 1976; Kremer 1993; Tsirel 2004; Korotayev, Malkov, Khaltourina 2006a; Korotayev, S. Malkov 2012; Korotayev 2012, 2013; Korotayev, A. Malkov 2016; Grinin, Markov, Korotayev 2013, 2014, 2015. развитием, когда технологическое развитие (наиболее ярко проявлявшееся именно в виде «биосферных революций» типа неолитической или промышленной) значительноускоряло темпы роста населения, который (в силу действия принципа «чем больше людей, тем больше изобреталей») через механизмы коллективного обучения ускорял наступление каждой следующей «биосферной революции» (как правило, соответствовашей новому технологическому прорыву). При этом А. А. Фомин (2018) достаточно убедительно показывает математически, что «если имеется гиперболический рост количества эволюционных единиц (обобщенное название народонаселения на случай и биологической эволюции), то прирост числа этих единиц в одно и то же количество раз $\alpha$ будет приводить к тому, что промежутки времени между моментами этих приростов будут сокращаться в точно такое же количество раз $\alpha$ » - то есть, если между биосферными революциями население в среднем увеличивается в $\alpha$ раз, то и промежутки времени между каждой последующей парой биосферных революций будет сокращаться в $\alpha$ раз (Отметим, что последняя $\alpha$ это ничто иное, как то, что А. Д. Панов (2005: 128) называет «коэффициентом ускорения исторического времени, показывающим, во сколько раз каждая последующая эпоха ${ }^{43}$ короче предыдущей»). При этом проведенные А. А. Фоминым эмпирические расчеты подтвердили, что среднее значение увеличения населения между биосферными революциями примерно равно среднему значению укорачивания времени между биосферными революциями. Расчеты Фомина показывают, что и то, и другое значение располагаются в интервале 2,5-2,8, что достаточно близко значению коэафициента $\alpha$, эмпирически рассчитанному Пановым (2,67, см., например: Панов 2005: 130).

Уже из того, что среднее значение увеличения населения между биосферными революциями примерно равно среднему значению укорачивания 43 Т.е. промежуток между «биосферными революциями»/ «скачками сложности». - А.К. 
времени между биосферными революциями вытекает, что темпы роста глобальной сложности $(\mathrm{dn} / \mathrm{dt})$ должныбытьпропорциональнычисленности населения Земли $(\mathrm{N})$, а значит, что $\mathrm{N}$ и $\mathrm{dn} / \mathrm{dt}$ должны расти по одному закону. Действительно, если $\mathrm{N}$ увеличилос в $\alpha$ раз, то расстояние до следующей биосферной революции должно сократиться в $\alpha$ раз. Но скорость роста глобальной сложности $(\mathrm{dn} / \mathrm{dt})$ мы рассчитываем как раз как «1» деленную на число лет между биосферными революциями (что и дает нам «число биосферных революций в год»). Таким образом, сокращение времени между биосферными революциями в $\alpha$ раз по определению означает увеличение интенсивности глобальной макроэволюции (dn/ $\mathrm{dt})$ в $\alpha$ раз. А значит, что если увеличение $\mathrm{N}$ в $\alpha$ раз сопровождается сокращением времени между биосферными революциями в $\alpha$ раз, а сокращение времени между биосферными революциями в $\alpha$ раз означает увеличение интенсивности глобальной макроэволюции $(\mathrm{dn} / \mathrm{dt})$ в $\alpha$ раз, то увеличение $\mathrm{N}$ в $\alpha$ раз должно сопровождаться увеличением $\mathrm{dn} / \mathrm{dt}$ в $\alpha$ раз, что значит что $\mathrm{N}$ пропорционально $\mathrm{dn} / \mathrm{dt}$, и они растут по одному закону

Покажем это теперь более формально. Прежде всего отметим, что представление количества эволюционных единиц в виде сумм возрастающих геометрической и/или арифметической прогрессий, а приближения к точке сингулярности в виде суммы убывающей геометрической прогрессии интервалов времени между фазовыми переходами впервые было сформулировано в одной из работ С. В. Циреля (2009). Однако, ввиду весьма сжатого и ненаглядного изложения этих представлений в упомянутой статье проведем иное более наглядное доказательство. Так как движение от одной биосферной революции до другой сопровождается ростом населения $\mathrm{N}$ в $\alpha$ раз и увеличением индекса глобальной сложности n на одну единицу получаем:

$$
N=k \cdot \alpha^{n}
$$

где $\mathrm{k}$ - коэффициент пропорциональности между $\mathrm{N}$ и $\alpha^{\mathrm{n}} .44$

Так как

$$
N_{t}=\frac{\mathrm{C}_{2}}{2027-t}
$$

получаем:

$$
k \cdot \alpha^{n}=\frac{\mathrm{C}_{2}}{2027-t} .
$$

Отсюда:

$$
\begin{aligned}
& \ln \left(k \cdot \alpha^{n}\right)=\ln \left(\frac{C_{2}}{2027-t}\right), \\
& \ln (k)+\ln \left(\alpha^{n}\right)=\ln \left(\frac{C_{2}}{2027-t}\right), \\
& \ln (k)+n \ln (\alpha)=\ln \left(\frac{C_{2}}{2027-t}\right), \\
& n=\frac{\ln \left(\frac{C_{2}}{2027-t}\right)-\ln (k)}{\ln (\alpha)} .
\end{aligned}
$$

Дифференцируя выражение (25), получаем:

$$
\frac{d n}{d t}=\frac{1}{\ln (\alpha)} \cdot \frac{1}{2027-t},
$$

или

$$
\frac{d n}{d t}=\frac{C_{1}}{2027-t},
$$

где $\mathrm{C}_{1}=1 / \ln (\alpha){ }^{45}$

Таким образом мы аналитически получаем, что если население $(\mathrm{N})$ растет гиперболически по закону $\mathrm{N}_{\mathrm{t}}=\mathrm{C}_{2} / 2027$-t, а между индексом глобальной сложности (n) и численностью населения Земли (N) существует соотношение $\mathrm{N}=\mathrm{k} \cdot \alpha^{\mathrm{n}}$, то темпы роста глобальной сложности $(\mathrm{dn} / \mathrm{dt})$ будут расти по тому же гиперболическому закону $(\mathrm{dn} / \mathrm{dt}=$

44 Отметим, что проведенная А. А. Фоминым (2018) эмпирическая проверка подтвердила наличие этой нетривиальной зависимости.

45 Отметим между прочим, что проведенные нами расчеты, позволили нам установить аналитически значение параметра $\mathrm{C}_{1}$ в уравнении (11). 
$\left.\mathrm{C}_{1} / 2027-\mathrm{t}\right)$, что и численность населения Земли.

Итак, проведенные расчеты заставляют предполагать, что то обстоятельство, что ТЕМПЫ роста глобальной сложности в ряде Панова (dn/ $\mathrm{dt})$ и численность населения Земли (N) вплоть до начала 1970-х годов росли по одному и тому же закону $\left(\mathrm{x}_{\mathrm{t}}=\mathrm{C} / 2027-\mathrm{t}\right)$, является отнюдь не случайностью, а проявлением достаточно глубокой закономерности. Таким образом, на социальной фазе универсальной и глобальной истории гиперболический рост темпов увеличения глобальной сложности и гиперболический рост численности населения Земли оказываются двумя теснейшим образом связанными сторонами единого процесса.

\section{Приложение 2.}

O некоторых закономерностях ускорения темпов глобального макроэволюционного развития. Дополнительные расчеты

Как было показано А. Д. Пановым ${ }^{46}$, для построенного им ряда «биосферных революций» наблюдается следующее соотношение:

$$
t_{n}=t^{*}-\frac{T}{\alpha^{n}}
$$

«где $\alpha>1$ - коэффициент ускорения исторического времени, показывающий, во сколько раз каждая последующая эпоха короче предыдущей, Т задает длительность всего описываемого промежутка времени $^{47}, \mathrm{n}$ - номер революции, а t*- некоторый момент времени, который можно назвать моментом сингулярности» (Панов 2005: 128). Отметим, что, как мы показали выше, $\mathrm{n}$ также вполне можно интерпретировать как индекс глобальной сложности.

46 См., например: Панов 2004, 2005, 2008; Panov 2005.

47 Как уже упоминалось выше, $T$ вполне можно рассматривать как время существования жизни на Земле и приравнивать к 4 млрд (лет).
Для дальнейших расчетов А. Д. Панов (2005: 129) преобразует уравнение (27) следующим образом:

$$
\lg \left(t^{*}-t_{n}\right)=\lg (T)-n \cdot \lg (\alpha) .
$$

Однако А. А. Фомин (2018) показывает, что для дальнейшего анализа модели Панова лучше использовать несколько другой вариант преобразования уравнения (27):

$$
\ln \left(t^{*}-t_{n}\right)=\ln (T)-n \cdot \ln (\alpha) .
$$

Действительно, уравнение (29) может быть переписано следующим образом:

$$
\begin{aligned}
& n \cdot \ln (\alpha)=\ln (T)-\ln \left(t^{*}-t_{n}\right), \\
& n=\frac{\ln (T)}{\ln (\alpha)}-\frac{1}{\ln (\alpha)} \cdot \ln \left(t^{*}-t_{n}\right), \\
& n_{t}=A-C_{1} \cdot \ln \left(t^{*}-t\right), \\
& \text { где } \mathrm{A}=\ln (\mathrm{T}) / \ln (\alpha), \text { а } \mathrm{C}_{1}=1 / \ln (\alpha) .
\end{aligned}
$$

В то же самое время, как мы помним, алгебраическое уравнение (19) является решением следующего дифференциального уравнения:

$$
\frac{d n}{d t}=\frac{\mathrm{C}_{1}}{t^{*}-t} \text {. }
$$

Таким образом, мы получаем те самые уравнения (19) и (11), которые были получены нами несколько иным путем.

Отметим, что по расчетам А. Д. Панова значение параметра $\alpha$ оказалось равным 2,67, что, как заметил сам Панов, является крайне близким численному значению числа е $(2,718 \ldots)$, и нельзя исключать, что «коэффициент ускорения исторического времени» окажется, действительно, столь близким к числу е, что параметр $\alpha$ в уравнениях (11), (31) и (0) можно заменить на е. В этом случае, набор уравнений, описывающих гиперболическое ускорение темпов глобального макроэволюционного развития оказывается особенно элегантным по своей простоте. Действительно, с учетом того, что в уравнении 


$$
n_{t}=A-C_{1} \cdot \ln (2027-t),
$$

$A=\ln (\mathrm{T}) / \ln (\alpha)$, а $C_{1}=1 / \ln (\alpha)$, подставляя е вместо $\alpha$, получаем:

$$
n_{t}=\ln (T)-\ln (2027-t)
$$

С учетом того, что в уравнении

$$
\frac{d n}{d t}=\frac{\mathrm{C}_{1}}{2027-t}
$$

$C_{1}=1 / \ln (\alpha)$, подставляя е вместо $\alpha$, получаем:

$$
\frac{d n}{d t}=\frac{1}{2027-t}
$$

Кроме того, уравнение ${ }^{48}$

$$
N=k \cdot \alpha^{n}
$$

при подстановке е вместо $\alpha$ приобретает вид

$$
N=k \cdot e^{n},
$$

из чего вытекает, что

$$
n=\ln (N)-\ln (k),
$$

В результате, набор уравнений, описывающих гиперболическое ускорение темпов глобального макроэволюционного развития оказывается действительно элегантным по своей простоте:

$$
\begin{aligned}
& n_{t}=\ln (T)-\ln (2027-t), \\
& \frac{d n}{d t}=\frac{1}{2027-t} \\
& N=k \cdot e^{n}, \\
& n=\ln (N)-\ln (k),
\end{aligned}
$$

где, напомним, $\mathrm{n}$ обозначает индекс глобальной сложности, Т - время существования жизни на Земле ( 4 млрд лет), а $\mathrm{N}$ - численность населения Земли.

Однако, конечно, трудно не согласиться с А. Д. Пановым (2005: 130) в том, что «вопрос о том, есть ли в [том, что значение коэффициента $\alpha$ близко значению числа е,] глубокий смысл, остается открытым»...

48 Отметим, что подсчеты А. А. Фомина (2018) показывают, что если при расчете при помощи уравнения (11) в качестве $\mathrm{t}$ брать не момент начала периода по которому вычисляется производная, а его середину, то значение параметра $\mathrm{C}_{1}$ оказывается ближе скорее к 1 , чем к 2 .

\section{Библиография}

Акаев А. А. 2010. Фундаментальные пределы экономического роста и потребления. Системный мониторинг глобальных и региональных рисков 2: 12-30.

Акаев А.А., Коротаев А.В., Малков С.Ю. 2014. Современная ситуация и контуры будущего. Комплексный системный анализ, математическое моделирование и прогнозирование развития стран БРИКС. Предварительные результаты / Отв. ред. А.А. Акаев, А.В. Коротаев, С.Ю. Малков. М.: Красанд/URSS. C. 10-31.

Антисери Д., Реале Дж. 2001. Западная философия от истоков до наших дней. Античность, средневековье. СПб.: Петрополис (перевод на русский D. Antiseri, G. Reale, Il pensiero occidentale dalle origini ad oggi. Editrice LA SCUOLA, Brescia, 1983-1994).

Балашова Н. А., Савченко В. А., Сажиенко Е. В., Назаретян А. П. 2017. Мегаистория и глобальные вызовы XXI века: синергетическая модель. Историческая психология и социология истории 10(1): 193-212.

Биган Д. 2004. Планета человекообразных. B мире науки (11): 68-77.

Борисковский П. И. 1970. Ашельская культура. Большая советская энцииклопедия. Т. 2. М.: Советская энциклопедия. С. 471.

Борисковский П. И. 1974а. Олдовай. Большая советская эничиклопедия. Т. 18. М.: Советская энциклопедия. С. 369.

Борисковский П. И. 1974б. Мустьерская культура. Большая советская энщиклопедия. Т. 17. М.: Советская энциклопедия. С. 134.

Борисковский П. И. 1978. Шелльская культура. Большая советская эничиклопедия. Т. 29. М.: Советская энциклопедия. С. 377.

Вайнберг С. 1981. Первые три минутьл. Современный взгляд на происхождение Вселенной. М.: Энергоиздат. 
Вишневский А. Г. 1976. Демографическая револющия. М.: Статистика.

Вишневский А. Г. 2005. Избранные демографические трудыл. Т. 1.Демографическая теория и демографическая история. М.: Наука.

Вонг К. 2003. У колыбели Homo sapiens. B мире науки (11): 9-10.

Галимов Э. М. 2001. Феномен жизни: между равновесием и нелинейностью. Происхождение и принцииь эволюции. М.: Едиториал УРСС.

Гринченко С. Н. 2001. Социальная метаэволюция Человечества как последовательность шагов формирования механизмов его системной памяти. Электронный журнал «Исследовано в России» 145: 1652-1681.

Гринченко С. Н. 2004. Системная память живого (как основа его метаэволюиии и периодической структуры). М.: ИПИ РАН, Мир.

Гринченко С. Н. 2006. История Человечества с информатико-кибернетических позиций: проблемы периодизации. История $u$ Математика 1: 38-52.

Гринченко С.Н. 2007. Метаэволющчия (систем неживой, живой и социильно-технологической природы). М.: ИПИ РАН.

Гринченко С.Н. 2015. Моделирование: индуктивное и дедуктивное. Проблемы исторического познания / Отв. ред. К.В. Хвостова. М.: ИВИ РАН. С. 95-101.

Гринченко С. Н., Щапова Ю. Л. 2017. Палеоантропология, хронология ипериодизация археологической эпохи: числовая модель. Пространство и Время 1 (27): 72-82.

Дьяконов И. М. 1994. Пути истории. От древнейтего человека до наших дней. М.: Восточная литература.

Заварзин Г. А. 2003. Становление системы биогеохимическихциклов. Палеонтологический журнал (6): 16-24.

Зайцев А. И. 2001. Из наследия А. И. Зайцева. Т. 1. Культурный переворот в Греции VIII-V вв. до н.э. СПб.: Петрополис.

Зинькина Ю. В., Коротаев А. В. 2017. Социально- демографическое развитие стран Тропической Африки: Ключевые факторы риска, модифицируемье управляющие параметры, рекомендации. М.: Ленанд/URSS.

Зинькина, Ю. В., Шульгин, С. Г., Коротаев, А. В. 2016. Эволючия глобальных сетей. Закономерности, тенденции, модели. М.: Ленанд/URSS.

Капица С. П. 1992. Математическая модель роста населения мира. Математическое моделирование 4(6): 65-79.

Капица С. П. 1996. Феноменологическая теория роста населения Земли. Успехи физических наук 166(1): 63-80.

Капица С. П. 1999. Сколько людей жило, живет и будет жить на земле. М.: Наука.

Капица С. 2007. Демографический переход и будущее человечества. Вестник Европь (21): 7-16.

Келлер Б. М. 1975. Палеозойская группа (эра). Большая советская энииклопедия. Т. 19. М.: Советская энциклопедия.

Коротаев А. В. 2006. Периодизация истории Мир-Системы и математические макромодели социально-исторических процессов. История u Математика: Проблемь периодизации исторических макропрочессов / Ред. Л. Е. Гринин, А. В. Коротаев, С. Ю. Малков. М.: УРСС. С. 116-167.

Коротаев А. В. 2007. Макродинамика урбанизации Мир-Системы: количественный анализ. История и Математика: Макроисторическая динамика общества и государства / Ред. С. Ю. Малков, Л. Е. Гринин, А. В. Коротаев. М.: КомКнига/URSS. С. 21-39.

Коротаев А. В. 2010а. Компактные математические модели долгосрочного развития Мир-Системы. Уральский исторический вестник 3: 15-24.

Коротаев А. В. 2010б. Компактные математические модели развития Мир-Системы. Прогноз и моделирование кризисов и мировой динамики / Отв. ред. А. А. Акаев, А. В. Коротаев, Г. Г. Малинецкий. М.: ЛКИ/URSS. C. 70-92. 
Коротаев А. В. 2015. Глобальный демографический переход и фазы дивергенции - конвергенции центра и периферии Мир-Системы. Вестник Института экономики Российской академии наук (1): 149-162.

Коротаев А. В. 2016. Великая дивергенция и великая конвергенция как фазы процесса модернизации. География мирового развития. Выпуск 3 / Под ред. Л.М.Синцерова. М.: Товарищество научных изданий КМК. С. 4960.

Коротаев, А. В., Билюга, С. Э. 2016. О некоторых современных тенденциях мирового экономического развития. Вестник Института экономики Российской академии наук (4): 20-39.

КоротаевА.В.,БожевольновЮ.В. 2010.Некоторые общие тенденции экономического развития Мир-Системы. Прогноз и моделирование кризисов и мировой динамики / Ред. А. А. Акаев, А. В. Коротаев, Г. Г. Малинецкий. М.: ЛКИ/ URSS. C. 161-171.

Коротаев А. В., Комарова Н. Л., Халтурина Д. А. 2007. Законы истории. Вековые цикль u тысячелетние тренды. Демография. Экономика. Войны. М.: КомКнига/URSS.

Коротаев А. В., Малков А. С., Халтурина Д. А. 2005а. Законы истории: Математическое моделирование исторических макропрочессов (Демография. Экономика. Войны). М.: КомКнига/URSS.

Коротаев А. В., Малков А.С., Халтурина Д. А. $2005 б$. Компактная математическая макромодель технико-экономического и демографического развития Мир-Системы (1-1973 гг.) История $u$ синергетика: Математическое модели-рование соииальной динамики / Ред. С. Ю. Малков, А. В. Коротаев. М.: КомКнига/URSS. С. 6-48.

Коротаев А. В., Малков А. С., Халтурина Д. А. 2007. Законь истории: Математическое моделирование развития Мир-Системьл. Демография, экономика, культура. М.: КомКнига/ URSS.

Коротаев А. В., Малков А. С., Халтурина Д. А.
2008. Компактная математическая модель экономического и демографического развития Мир-Системы (1-1973 гг.). Экономика $u$ математические методы 44(4): 90-101.

Коротаев А. В., Марков А. В. 2006. Механизм гиперболического роста в биологических и социальных системах. Философские науки (11): 138-141.

Коротаев А. В., Халтурина Д. А. 2009. Современные тенденциии мирового развития. М.: ЛИБРОКОМ/ URSS.

Коротаев А. В., Халтурина Д. А., Божевольнов Ю. В. 2010. Законы истории. Вековые циикль и тысячелетние тренды. Демография. Экономика. Войны. 3-е изд. М.: ЛКИ/URSS.

Коротаев А. В., Халтурина Д. А., Малков А. С., Божевольнов Ю. В., Кобзева С. В., Зинькина Ю. В. 2010. Законы истории. Математическое моделирование и прогнозирование мирового $u$ регионального развития. 3-е изд., испр. и доп. М.: ЛКИ/URSS.

Кринг Д., Дурда Д. Д. 2004. День, когда мир был сожжен. В мире науки (3): 56-63.

Крылов О. В. 1999. Будет ли конец науки. Российский химический журнал 43(6): 96-106.

Крылов О. В. 2002. Динамика развития химической науки. Российский химический журнал 46(3): 96-99.

Крылов О. В. 2007. Современная наука: близкий конец или завершение очередного этапа? Российский химический журнал 51(3): 71-78.

Кэррол Р. 1992. Палеонтология и эволющчия позвоночных. Т. 1. М.: Мир.

Кэррол Р. 1993а. Палеонтология и эволющฺия позвоночных. Т. 2. М.: Мир.

Кэррол Р. 1993б. Палеонтология и эволюччия позвоночныхх. Т. 3. М.: Мир.

Лопатин Н. В. 1983. Древние биосферы и генезис горючих ископаемых. Палеонтология u эволючия биосферы. Труды XXV сессии всесоюзного палеонтологического общества. Л.: АН СССР.

Марков А. В., Анисимов В. А., Коротаев А. В. 
2010. Взаимосвязь размера генома и сложности организма в эволюционном ряду от прокариот к млекопитающим. Палеонтологический журнал (4): 3-14.

Марков А.В., Анисимов В.А., Коротаев А.В. 2011. Гиперэкспоненциальный рост минимального размера генома в эволюционном ряду от прокариот к млекопитающим. Эволющия 3: 113-154.

Марков А. В., Коротаев А. В. 2007. Динамика разнообразия фанерозойских морских животных соответствует модели гиперболического роста. Журнал общей биологии 68(1): 3-18.

Марков А. В., Коротаев А. В. 2008 a. Гиперболический рост разнообразия морской и континентальной биот фанерозоя и эволюция сообществ. Журнал общзей биологии 69(3): 175194.

Марков А. В., Коротаев А. В. 20086. Гиперболический рост биоразнообразия В фанерозое объясняется ростом сложности и устойчивости сообществ. Современные проблемы биологической эволючии / Ред. А. С. Рубцов. М.: Издательство Государственного Дарвиновского музея. С. 278-323.

Марков А. В., Коротаев А. В. 2008в. Динамика разнообразия морской и континентальной биоты фанерозоя соответствует модели гиперболического роста. Геобиосферные события и история органического мира / Ред. Т. Н. Богданова, Н. Г. Крымгольц. СПб.: Палеонтологическое общество РАН. С. 108-110.

Марков А. В., Коротаев А. В. 2009а. Гиперболический рост в живой природе $и$ обществе. М.: Либроком/URSS.

Марков А. В., Коротаев А. В. 2009б. О причинах ускорения роста разнообразия морской и континентальной биоты фанерозоя: факты и модели. Синтетическая теория эволючии: состояние, проблемы, перспективы / Ред. И. Д. Соколов. Луганск: Элтон-2. С. 37-39.
Муратов М. В., Вахрамеев В. А. 1974. Мезозойская группа (эра). Большая советская эничклопедия. Т. 16 М.: Советская энциклопедия. С. 6-8.

Назаретян А. П. 2004. Цивилизационные кризисы в контексте Универсальной истории. Изд. 2-е., переработанное и дополненное. М.: Пер се.

Назаретян А. П. 2005. Знает ли история сослагательное наклонение? (Мегаисторический взгляд на альтернативные модели). Философские науки (2): 7-18.

Назаретян А. П. 2009. Смыслообразование как глобальная проблема современности: синергетический взгляд. Bonpocbl философии (5): 3-19.

Назаретян А. П. 2013. Середина XXI века: загадка сингулярности. Философские науки (9): 15-24.

Назаретян А. П. 2014. «Национальная идея»: Россия в глобальных сценариях XXI века. Историческая психология и сочиология истории 7(1): 75-91.

Назаретян А. П. 2015a. Мегаистория и ее «загадочная сингулярность». Вестник Российской академии наук 85(8): 755-764. DOI: $10.7868 / \mathrm{S} 0869587315080216$

Назаретян А. П. 2015б. Нелинейное будущеее. Мегаистория, синергетика, культурная антропология и психология в глобальном прогнозировании. М.: Аргамак-Медиа.

Панов А.Д. 2004. Автомодельный аттрактор социально-биологической эволюции на Земле и гипотеза самосогласованного галактического происхождения жизни. Бюллетень Научнокультурного иентра SETI Академии космонавтики им. К.Э.Циолковского 7(24): 4-21.

Панов А. Д. 2005. Сингулярная точка истории. Общественные науки и современность (1): 122-137.

Панов А. Д. 2006. Сингулярность Дьяконова. История и математика 1: 31-37.

Панов А.Д. 2008. Универсальная эволюичя $и$ проблема поиска внеземного разума (SETI). М.: ЛКИ/URSS. 
Панов А. Д. 2009. Наука как явление эволюции. Эволюччи 1: 99-127.

Панов А. Д. 2013. Макроэволюция и наука. Науковедческие исследования. М.: Российкая академия наук, Институт информации по общественным наукам. С. 215-256.

Подлазов А. В. 2000. Теоретическая демография как основа математической истории. М.: ИПМ РАН

Подлазов А. В. 2001. Основное уравнение теоретической демографии и модель глобального демографического перехода. М.: ИПМ РАН.

Подлазов А. В. 2002. Теоретическая демография. Модели роста народонаселения и глобального демографического перехода. Новое в синергетике. Взгляд в третье тысячелетие / Ред. Г. Г. Малинецкий, С. П. Курдюмов. М.: Наука. С. 324-345.

Подлазов, А. В. (2017). Теория глобального демографического процесса. Вестник Российской академии наук (6): 520-531.

Римашевская Н. М., Доброхлеб В. Г., Медведева Е. А, Крошилин С. В. 2012. Демографический переход - специфика российской модели. Народонаселение (1): 23-31.

Розанов А. Ю. 1986. Что произошло 600 миллионов лет назад. М.: Наука.

Розанов А. Ю. 2003. Ископаемые бактерии, седиментогенез и ранние стадии эволюции биосферы. Палеонтологический журнал (6): 41-49.

Розанов А. Ю., Заварзин Г. А. 1997. Бактериальная палеонтология. Вестник РАН 67(3): 241-245.

Романчук А. А., Медведева О. В. 2009. Глобальный демографический переход и его биологические параллели. Эволючия 1: 244-269.

Садовничий В. А., Акаев А.А., Коротаев А.В., Малков С.Ю. 2014. Комплексное моделирование и прогнозирование развития стран БРИКС в контексте мировой динамики. М.: Наука.

Федонкин М. А. 2003. Сужение геохимического базиса жизни и эвкариотизация биосферы: причинная связь. Палеонтологический журнал (6): 33-33.

Фомин А. А. 2018. Сквозная гиперболическая эволюция от биосферы до техносферы. Эволюиия 10.

Фоули Р. 1990. Ещее один неповторимый вид. Экологические аспекты эволюции человека. М.: Мир.

Цирель С. В. 2009. Скорость эволюции: пульсирующая, замедляющаяся, ускоряющаяся. Эволючия 1: 62-98.

Цирель С. В. 2018. Big History и Singularity как метафоры, гипотезы и прогноз. Эволюиия 10.

Шанцер Е. В. 1973. Кайнозойская группа (эра). Большая советская энииклопедия. Т. 11. М.: Советская энциклопедия. С. 185-186

Щапова Ю. Л., Гринченко С. Н. 2017. Введение в теорию археологической эпохи: числовое моделирование и логарифмические икаль пространственно-временных координат. М.: Исторический факультет Моск. Ун-та, Федеральный исслед. Центр «Информатика и управление» РАН.

Ясперс, К. 1991. Смысл и назначение истории. М.: Политиздат.

A. H. 1975. Mesozoic era. The New Encyclopedia Britanica, 15th ed., vol. 11, Chicago: Encyclopedia Britanica, Inc. pp. 1013-1017.

A. P. 1975. Cenozoic era. The New Encyclopedia Britanica, 15th ed., vol. 3, Chicago: Encyclopedia Britanica, pp. 1079-1083.

Adams H. 1969 [1909]. The Rule of Phase Applied to History. The Degradation of the Democratic Dogma / H. Adams. New York, NY: Harper \& Row. P. 267-311.

Alvarez L. W., Alvarez W., Asaro F., Michel H. V. 1980. Extraterrestrial cause for the CretaceousTertiary extinction. Science 208(4448): 1095 1108. DOI: $10.1126 /$ science.208.4448.1095

Barrow J.D., J. Silk J. 1980. The structure of the early universe. Scientific American 242 (4): 118-128.

Begun D.R. 2003. Planet of the apes. Scientific American 289 (2): 64-73. 
Burenhult G. 1993. (Ed.). The First Humans: Human Origins and History to 10,000 BC. San Francisco: Harper.

Caldwell J. C., Caldwell B. K., Caldwell P., McDonald P.F., Schindlmayr T. 2006. Demographic transition theory. Dordrecht: Springer. DOI: 10.1007/978-14020-4498-4

Callaghan V., Miller J., Yampolskiy R., Armstrong S. 2017. Technological Singularity. Dordrecht: Springer. DOI: 10.1007/978-3-662-54033-6

Carrol R. L. 1988. Vertebrate Paleontology and Evolution. New York: W.H. Freeman and Company.

Cervellati M., Sunde U., Zimmermann K. F. 2017. Demographic dynamics and long-run development: insights for the secular stagnation debate. Journal of Population Economics 30(2): 401-432. DOI: https://doi.org/10.1007/s00148-016-0626-8

Chaisson E. J. 2006. Epic of Evolution: Seven Ages of the Cosmos. New York: Columbia University Press.

Chesnais J. C. 1992. The demographic transition: Stages, patterns, and economic implications. Oxford: Clarendon Press.

Choi Y. 2016. Demographic transition in sub-Saharan Africa: Implications for demographic dividend. Demographic Dividends: Emerging Challenges and Policy Implications. Dordrecht: Springer. P. 61-82. DOI: https://doi.org/10.1007/978-3-31932709-9 4

Christian D. 1991. The case for «big history'. Journal of World History 2 (2): 223-237.

Christian D. 2008. Big History: The Big Bang, Life on Earth, and the Rise of Humanity. Chantilly, VA: The Teaching Company.

Diakonov I. M. 1999. The paths of history. Cambridge: Cambridge University Press.

Dyson T. 2010. Population and development. The demographic transition. London: Zed Books.

Eden A. H., Moor J. H., Søraker J. H., E. Steinhart. 2012. (Eds.). Singularity Hypotheses: A Scientific and Philosophical Assessment. Berlin: Springer. DOI: 10.1007/978-3-642-32560-1
Foerster H. von, Mora P. M., Amiot L. W. 1960. Doomsday: Friday, 13 November, AD 2026. Science 132 (3436): 1291-1295.

Gordon R. J. 2012. Is US economic growth over? Faltering innovation confronts the six headwinds. Cambridge, MA: National Bureau of Economic Research.

Gould W. T. S. 2009. Population and Development. London: Routledge.

Grinchenko S.N. 2006. Meta-evolution of Nature System - The Framework of History. Social Evolution \& History 5 (1): 42-88.

Grinchenko S.N. 2011. The Pre- and Post-History of Humankind: What is it? Problems of Contemporary World Futurology. Newcastle-upon-Tyne: Cambridge Scholars Publishing. P. 341-353.

Grinchenko S.N., Shchapova Y.L. 2010. Human History Periodization Models. Herald of the Russian Academy of Sciences 80 (6): 498-506. DOI: https://doi.org/10.1134/S1019331610060055

Grinchenko S.N., Shchapova Y.L. 2016. Archaeological epoch as the succession of generations of evolutive subject-carrier archaeological sub-epoch. Philosophy of Nature in Cross-Cultural Dimensions. Vienna: University of Vienna. P. 423-439.

Grinchenko S.N., Shchapova Y.L. 2017. Archaeological Epoch as the Succession of Generations of Evolutive Subject-Carrier Archaeological Sub-Epoch. Philosophy of Nature in Cross-Cultural Dimensions. Hamburg: Verlag Dr. Kovač. P. 478-499.

Grinin L., Korotayev A. 2015. Great Divergence and Great Convergence. A Global Perspective. New York, NY: Springer. DOI: 10.1007/978-3-31917780-9

Grinin L., Markov A., Korotayev A. 2013. On similarities between biological and social evolutionary mechanisms: Mathematical modeling. Cliodynamics 4(2): 185-228.

Grinin L. E., Markov A. V., Korotayev A. V. 2014. Mathematical modeling of biological and social evolutionary macrotrends. History \& Mathematics 
4: 9-48.

Grinin L. E., Markov A. V., Korotayev A. V. 2015. Modeling of Biological and Social Phases of Big History. Evolution 4: 111-150.

Heidmann J. 1989. Cosmic Odyssey. Cambridge: Cambridge University Press (Simon Mitton, Trans.).

Hoerner S. J. von. 1975. Population Explosion and Interstellar Expansion. Journal of the British Interplanetary Society 28: 691-712.

Huebner J. 2005. A possible declining trend for worldwide innovation. Technological Forecasting and Social Change 72(8): 980-986. DOI: https:// doi.org/10.1016/j.techfore.2005.01.003

J.B.W. 1975. Paleozoic era, upper. The New Encyclopedia Britanica, 15th ed., vol. 13, Chicago: Encyclopedia Britanica. P. 921-930.

Jaspers K. 1949. Vom Ursprung und Ziel der Geschichte. München: Piper.

Jaspers K. 1953. The Origin and Goal of History. London: Routledge \& Keegan Paul.

Jaspers K. 1955. Von Ursprung und Ziel der Geschichte. Frankfurt/Main: Fisher Bucherei.

Johansen A., Sornette D. 2001. Finite-time Singularity in the Dynamics of the World Population and Economic Indices. Physica A 294(3-4): 465-502. DOI: https://doi.org/10.1016/S03784371(01)00105-4.

Johanson D., Edgar B. 1996. From Lucy to Language. New York: Simon and Schuster.

Jones, C. 2018. Aging, secular stagnation and the business cycle. Washington, DC: International Monetary Fund.

Jones S. 1994. (Ed.). The Cambridge Encyclopedia of Human Evolution. Cambridge: Cambridge University Press.

Kapitza S. P. 1996. The phenomenological theory of world population growth. Physics-uspekhi 39(1): $57-71$.

Kapitza S. P. 2003. The statistical theory of global population growth. Formal descriptions of developing systems. Springer: Dordrecht. P. 11-35. DOI: https://doi.org/10.1007/978-94-010-0064-
2 2

Kapitza S. P. 2006. Global population blow-up and after. Hamburg: Global Marshall Plan Initiative.

Kapitza S. P. 2010. On the theory of global population growth. Physics-Uspekhi 53(12): 1287-1296.

Khaltourina D. A., Korotayev A. V. 2007. A modified version of a compact mathematical model of the World system economic, demographic, and cultural development. Mathematical Modeling of Social and Economic Dynamics / Ed. by M. G. Dmitriev, A. P. Petrov, N. P. Tretyakov. Moscow: RUDN. P. 274-277.

Khaltourina, D., Korotayev, A., \& Malkov, A. 2006. A Compact Macromodel of the World System Demographic and Economic Growth, 1-1973 CE. Cybernetics and Systems / Ed. by R. Trappl. Vol. 1. Vienna: Austrian Society for Cybernatic Research. P. 330-335.

Korotayev A. 2005. A compact macromodel of World System evolution. Journal of WorldSystems Research 11(1): 79-93. DOI: https://doi. org/10.5195/jwsr.2005.401

Korotayev A. V. 2006a. The world system history periodization and mathematical models of sociohistorical processes. History \& Mathematics: Analyzing And Modeling Global Development / Ed. by L. Grinin, V. de Munck A. Korotayev. Moscow: KomKniga/URSS. P. 39-98.

Korotayev A. 2006b. The World System Urbanization Dynamics: A Quantitative Analysis. History \& Mathematics: Historical Dynamics and Development of Complex Societies / Ed. by P. Turchin, L. Grinin, A. Korotayev, V. C. de Munck. Moscow: KomKniga/URSS. P. 44-62.

Korotayev A. 2007a. Compact mathematical models of world system development, and how they can help us to clarify our understanding of globalization processes. Globalization as Evolutionary Process: Modeling Global Change / Ed. by G. Modelski, T. Devezas, W. R. Thompson. London: Routledge. P. 133-160.

Korotayev A. 2007b. Secular Cycles and Millennial Trends: A Mathematical Model. Mathematical 
Modeling of Social and Economic Dynamics / Ed. by M. G. Dmitriev, A. P. Petrov, N. P. Tretyakov. Moscow: RUDN. P. 118-125.

Korotayev A. 2008. Globalization and mathematical modeling of global development. Hierarchy and Power in The History Of Civilizations: Political Aspects Of Modernity / Ed. by L. E. Grinin, D. D. Beliaev, A. V. Korotayev. Moscow: LIBROCOM/ URSS. P. 225-240.

Korotayev A. 2009. Compact mathematical models of the world system development and their applicability to the development of local solutions in third world countries. Systemic Development: Local Solutions in a Global Environment / Ed. by J. Sheffield. Litchfield Park, AZ: ISCE Publishing. P. 103-116.

Korotayev A. 2012. Globalization and mathematical modeling of global development. Globalistics and Globalization Studies 1: 148-158.

Korotayev A. 2013. Globalization and Mathematical Modeling of Global Evolution. Evolution: Development within Big History, Evolutionary and World-System Paradigms. Yearbook / Ed. by L. E. Grinin and A. V. Korotayev. Volgograd: Uchitel. P. 69-83.

Korotayev A., Goldstone J., Zinkina J. 2015. Phases of global demographic transition correlate with phases of the Great Divergence and Great Convergence. Technological Forecasting and Social Change 95: 163-169. DOI: https://doi.org/10.1016/j. techfore.2015.01.017

Korotayev A., Khaltourina D. 2006. Introduction to Social Macrodynamics: Secular Cycles and Millennial Trends in Africa. Moscow: KomKniga/ URSS.

Korotayev A., Malkov A. 2016. A compact mathematical model of the World System economic and demographic growth, 1 CE - 1973 CE. International Journal of Mathematical Models and Methods in Applied Sciences 10: 200-209.

Korotayev A., Malkov A., Khaltourina D. 2006a. Introduction to Social Macrodynamics: Compact Macromodels of the World System Growth.
Moscow: KomKniga/URSS.

Korotayev A., Malkov A., Khaltourina D. 2006 b. Introduction to Social Macrodynamics: Secular Cycles and Millennial Trends. Moscow: KomKniga/ URSS.

Korotayev A., Malkov S. 2012. Mathematical Models of the World-System Development. Routledge Handbook of World-Systems Analysis. Edited by Salvatore Babones and Christopher Chase-Dunn. London: Routledge. P. 158-161.

Korotayev A. V., Markov A. V. 2014. Mathematical Modeling of Biological and Social Phases of Big History. Teaching \& Researching Big History: Exploring a New Scholarly Field / Ed. by L. E. Grinin, D. Baker, E. Quaedackers, A. V. Korotayev. Volgograd: Uchitel. P. 188-219.

Korotayev A. V., Markov A. V. 2015. Mathematical modeling of biological and social phases of big history. Globalistics and Globalization Studies 4: 319-343.

Korotayev A., Zinkina J. 2017. Systemic boundary issues in the light of mathematical modeling of world-system evolution. Journal of Globalization Studies 8(1): 78-96.

KremerM. 1993. Population Growth and Technological Change: One Million B.C. to 1990. The Quarterly Journal of Economics 108: 681-716. DOI: https:// doi.org/10.2307/2118405

Kurzweil R. 2001. The Law of Accelerating Returns. KurzweilAI.net 3-7-2001. URL: http:/www. kurzweilai.net/articles/art0134.html?printable=1

Kurzweil R. 2005. The Singularity Is Near: When Humans Transcend Biology. New York: Viking Penguin.

LePoire D. J. 2005. Application of logistic analysis to the history of physics. Technological Forecasting and Social Change 72(4): 471-479. DOI: https:// doi.org/10.1016/S0040-1625(03)00044-1

LePoire, D. J. 2009. Exploration of Connections between Energy Use and Leadership Transitions. Systemic Transitions. New York: Palgrave Macmillan. P. 205-220. DOI: https://doi. org/10.1057/9780230618381_10 
LePoire D. 2013. Potential Economic and Energy Indicators of Inflection in Complexity. Evolution 3: 108-118.

LePoire D. 2015. Interpreting» big history» as complex adaptive system dynamics with nested logistic transitions in energy flow and organization. Emergence: Complexity and Organization 17(1): 1E. DOI: 10. emerg/10.17357.dbe7c8d6fae7f082c4 f33c $5 b 35 d f 8287$

LePoire D. J. 2016. Exploring Temporal Patterns in Big History Dynamics. KronoScope 16(2): 229249. DOI: $10.1163 / 15685241-12341358$

Livi-Bacci M. 2012. A concise history of world population. Chichester: Wiley-Blackwell.

Maddison A. 2007. Contours of the World Economy, 1-2030. Oxford: Oxford University Press.

Markov A. V., Anisimov V. A., Korotayev A. V. 2010. Relationship between genome size and organismal complexity in the lineage leading from prokaryotes to mammals. Paleontological Journal 44(4): 363373.

Markov A. V., Korotayev A. V. 2007. Phanerozoic marine biodiversity follows a hyperbolic trend. Palaeoworld 16(4): 311-318. DOI: https://doi. org/10.1016/j.palwor.2007.01.002

Markov A. V., Korotayev A. V. 2008. Hyperbolic growth of marine and continental biodiversity through the Phanerozoic and community evolution. Zhurnal obshchei biologii 69(3): 175-194.

Modis T. 2002. Forecasting the growth of complexity and change. Technological Forecasting and Social Change 69(4): 377-404. DOI: https://doi. org/10.1016/S0040-1625(01)00172-X

Modis T. 2003. The Limits of Complexity and Change. The Futurist 37(3): 26-32.

Modis T. 2005. Discussion of Huebner article comments by Theodore Modis. Technological Forecasting and Social Change 72: 987-988. DOI: 10.1016/j.techfore.2005.05.003

Modis T. 2012. Why the Singularity Cannot Happen. In Eden A. H., J. H. Moor, J. H. Søraker, and E. Steinhart. (Eds.). Singularity Hypothesis: A Scientific and Philosophical Assessment.
Berlin: Springer. P. 311-346. DOI: https://doi. org/10.1007/978-3-642-32560-1_16

Nazaretyan A.P. 2003. Power and wisdom: toward a history of social behavior. Journal of the Theory of Social Behaviour 33(4): 405-425. DOI: https://doi. org/10.1046/j.1468-5914.2003.00224.x

Nazaretyan A. P. 2005. Big (Universal) History Paradigm: Versions and Approaches. Social Evolution \& History 4(1): 61-86.

Nazaretyan A. P. 2015. Megahistory and its mysterious singularity. Herald of the Russian Academy of Sciences 85(4): 352-361. DOI: 10.1134/ S1019331615040061

Nazaretyan A. P. 2016. Non-Linear Futures: The "Mysterious Singularity" in View of MegaHistory. Between Past Orthodoxies and the Future of Globalization. Contemporary Philosophical Problems. Boston: Brill-Rodopi. P. 171-191.

Nazaretyan A. P. 2017. Mega-History and the TwentyFirst Century Singularity Puzzle. Social Evolution \& History 16(1): 31-52.

Nazaretyan A. 2018. The Polyfurcation Century: Does the Evolution on Earth Have a Cosmological Relevance? Journal of Big History 2(1): 27-41. D O I : Google's http://dx.doi.org/10.22339/ jbh.v2i1.2253

Orgel L.E. 1998. The origin of life - How long did it take? Origins of Life and Evolution of the Biosphere 28: 91-96.

Panov A. D. 2005. Scaling law of the biological evolution and the hypothesis of the self-consistent Galaxy origin of life. Advances in Space Research 36(2): 220-225. https://doi.org/10.1016/j. asr.2005.03.001

Panov A. D. 2011. Post-singular Evolution and Postsingular Civilizations. Evolution 2: 212-231.

Panov A. D. 2017. Singularity of Evolution and PostSingular Development. From Big Bang to Galactic Civilizations. A Big History Anthology. Volume III. The Ways that Big History Works: Cosmos, Life, Society and our Future / Ed. by B. Rodrigue, L. Grinin, A. Korotayev. Delhi: Primus Books. P. 370-402. 
Piketty T. 2014. Capital in the Twenty-First Century. Cambridge, MA: The Belknap Press of Harvard University Press.

Podlazov A. V. 2017. A theory of the global demographic process. Herald of the Russian Academy of Sciences 87(3): 256-266. DOI: 10.1134/S1019331617030054

Popović M. 2018. Technological Progress, Globalization, and Secular Stagnation. Journal of Central Banking Theory and Practice 7(1): 59100. DOI: https://doi.org/10.2478/jcbtp-2018-0004

Ranj B. 2016. chief futurist Ray Kurzweil thinks we could start living forever by 2029. Business Insider Apr. 20, 2016. URL: http://www.techinsider. io/googles-chief-futurist-thinks-we-could-startliving-forever-by-2029-2016-4.

Reher D. S. 2011. Economic and social implications of the demographic transition. Population and Development Review 37: 11-33. DOI: https://doi. org/10.1111/j.1728-4457.2011.00376.x

Sagan S. 1989. The Dragons of Eden: Speculations on the Evolution of Human Intelligence. New York: Ballantine Books.

Shanahan M. 2015. The technological singularity. Cambridge, MA: MIT Press.

Schopf J. W. 1991. (Ed.). Major Events in the History of Life. Boston: Jones and Bartlett Publishers.

Snooks G. D. 1996. The Dynamic Society: Exploring the Sources of Global Change. London: Routledge.

Snooks G. D. 2005. Big History or Big Theory? Uncovering the Laws of Life. Social Evolution \& History 4(1): 160-188.

Summers L. H. 2016. The age of secular stagnation: What it is and what to do about it. Foreign Affairs 95 (2): 2-9.

T.K. 1975. Paleozoic era, lower. The New Encyclopedia Britanica, 15th ed., vol. 13, Chicago: Encyclopedia Britanica, Inc. P. 916-920.

Taagepera R. 1976. Crisis around 2005 AD? A technology-population interaction model. General Systems 21: 137-138.

Taylor G., Tyers R. 2017. Secular stagnation: Determinants and consequences for Australia.
Economic Record 93(303): 615-650. DOI: https:// doi.org/10.1111/1475-4932.12357

Teulings C., Baldwin R. 2014. (Eds.). Secular Stagnation: Facts, Causes, and Cures. London: CEPR.

Tsirel S. V. 2004. On the Possible Reasons for the Hyperexponential Growth of the Earth Population. Mathematical Modeling of Social and Economic Dynamics / Ed. by M. G. Dmitriev, A. P. Petrov. Moscow: Russian State Social University. P. $367-$ 369.

UN Population Division. 2018. United Nations population division database. New York, NY: United Nations. URL: http://www.un.org/ esa/ population.

Weinberg S. 1977. The First Three Minutes: A Modern View of the Origin of the Universe. New York, NY: Basic Books.

Wood B. 1992. Origin and evolution of the genus homo. Nature 355: 783-790. doi:10.1038/355783a0 
